\begin{abstract}
A Agricultura Familiar e a Construção Social de Mercados em Assentamentos Rurais do Município de Mambaí, Nordeste de Goiás.
\end{abstract}

Igor Amaury Aveline

\begin{abstract}
Dissertação submetida ao Programa de PósGraduação em Tecnologia, Consumo e Sustentabilidade do Centro de Desenvolvimento Sustentável da Universidade de Brasília como requisito parcial para obtenção do grau de Mestre em Desenvolvimento Sustentável.
\end{abstract}

Orientador: Eric Sabourin 


\title{
A Agricultura Familiar e a Construção Social de Mercados em Assentamentos Rurais do Município de Mambaí, Nordeste de Goiás.
}

\author{
Igor Amaury Aveline
}

Dissertação submetida ao Programa de Pós-Graduação em Tecnologia, Consumo e Sustentabilidade do Centro de Desenvolvimento Sustentável da Universidade de Brasília como requisito parcial para obtenção do grau de Mestre em Desenvolvimento Sustentável.

Aprovado por:

Orientador: Eric Sabourin (Centro de Desenvolvimento Sustentável CDS/UnB e Centre de Coopération Internationale em Recherche Agronomique pour le Développement - Cirad)

Profa. Dra. Doris Sayago (Centro de Desenvolvimento Sustentável $\mathrm{CDS} /$ UnB)

Prof. Dr. Stéphane Guéneau (Centre de Coopération Internationale en Recherche Agronomique pour le Développement - Cirad e Universidade Federal do Maranhão - UFMA) 


\section{Aveline, Igor Amaury}

A Agricultura Familiar e a Construção Social de Mercados em Assentamentos Rurais do Município de Mambaí, Nordeste de Goiás. Brasília, 2016 111p:Il.

Orientador: Eric Sabourin

Dissertação de Mestrado Acadêmico em Tecnologia, Consumo e Sustentabilidade. Centro de Desenvolvimento Sustentável da Universidade de Brasília

1. Agricultura familiar: mercados. 2. Construção social de mercados. 3. Teoria da reciprocidade. 4. Mambaí, Goiás.

É concedida à Universidade de Brasília permissão para reproduzir cópias desta dissertação e emprestar ou vender tais cópias, somente para propósitos acadêmicos ou científicos. O autor reserva outros direitos de publicação e nenhuma parte desta dissertação de mestrado pode ser reproduzida sem a autorização por escrito do autor. 


\section{AGRADECIMENTOS}

A utopia se desintegra diante da dureza da realidade de sonhadores que vivem hoje sua transformação e a resistência de suas práticas e relações cotidianas. Gostaria de agradecer, em primeiro lugar, a todos que vivem seus sonhos e lutam por um mundo onde caibam todos.

Agradeço ao professor Eric Sabourin por sua confiança, atenção e sobriedade em nossos diálogos e excelente relação de orientação. Agradeço ao professor Thomas Ludewigs que primeiro me incentivou a desenvolver a presente pesquisa e por acreditar em uma universidade transformadora buscando integrar ensino, extensão e pesquisa na prática acadêmica.

Agradeço a todos os agricultores familiares que permitiram 0 desenvolvimento desta pesquisa.

Agradeço ao CIRAD e à CAPES, ao Projeto SOCIOBIOCERRADO, aos professores Stéphane Guéneau, Carlos Passos, Denise Barbosa, Ludivine Eloy e outros que contribuíram direta ou indiretamente com a presente pesquisa. Agradeço aos colegas de curso pelos diálogos, conselhos e partilhas.

Agradeço à Fabiana Peneireiro, Helena Maltez, Renata Zambello, Maria Elena Ferreira, Rodrigo Junqueira, Denise Amador, Patrícia Vaz, Gilberto Neves, Guilherme Mamede, Yumi Parralego e outros amigos integrantes do Mutirão Agroflorestal, por compartilharem alegria e entusiasmo na vida e na luta diária pela agroecologia e sintropia no mundo.

Agradeço à Bia Medeiros e Christophe Aveline, pelo apoio incondicional, meus grandes mestres, para toda a vida. Agradeço a toda família! 


\section{RESUMO}

O município de Mambaí, localizado dentro da Área de Proteção Ambiental (APA) Nascentes do Rio Vermelho, no nordeste do estado de Goiás, Brasil, abriga seis assentamentos rurais da reforma agrária, correspondendo a um total de 313 famílias. Apesar do contexto de pobreza, ausência de apoio do poder público e da tendência à precarização da vida nos assentamentos, vários de seus agricultores familiares têm estruturado diferentes estratégias de comercialização da produção agrícola e extrativista. A pesquisa propõe analisar o processo de construção social dos mercados destes atores e caracterizar o papel das relações de reciprocidade na construção e sustentação de cada estratégia comercial identificada. A metodologia associou análises bibliográficas e documentais, entrevistas semi-estruturadas e abertas e observações participantes. Identificamos diversas formas comerciais desenvolvidas pelos agricultores assentados na região. Os resultados indicam que cada uma das formas comerciais são mobilizadas por diferentes práticas de ajuda mútua, de trocas não monetárias, de repartição de produtos e de compartilhamento de recursos (saberes, expectativas, excedentes etc). Estas práticas cumprem diferentes papéis, em particular nas diversas formas de venda direta, permitindo o diálogo e a partilha de informações, gerando interconhecimento, respeito mútuo, simpatia ou amizade e confiança. A empatia mútua gerada por estas relações induzem a geração de valores afetivos e éticos entre produtor e cliente e, progressivamente, a fidelização da relação de troca mercantil e a reprodução de solidariedades, tendendo a um equilíbrio nas relações de troca. Concluiu-se que essas relações, práticas e valores contribuem de forma incisiva na sustentação das estratégias de comercialização dos agricultores pesquisados.

Palavras-chave: Agricultura familiar: mercados; Construção social de mercados; Teoria da reciprocidade; Mambaí, Goiás. 


\begin{abstract}
The municipality of Mambaí, located inside the Environmental Protection Area (APA) Nascentes do Rio Vermelho, in the northeastern state of Goiás, Brazil, host six rural settlements of policy agrarian reform, housing 313 families. Despite the context of poverty, lack of government support and the trend towards precariousness of life in these settlements, several family farmers have structured different marketing strategies of production, agricultural and extractive. The research aims to analyze the process of social construction of markets for these actors and characterize the role of practices and relations of reciprocity in building and sustaining each identified business strategy. We identified several commercial forms developed by the settled farmers in the area studied. The main results indicate that each of commercial forms are mobilized by different mutual aid practices, nonmonetary exchanges, sharing of goods and resources (knowledge, expectations, surplus etc.). These practices fulfill different roles, in particular in the various forms of direct sales, allowing dialogue and sharing information, generating inter-knowledge, mutual respect, sympathy or friendship and trust. Mutual empathy generated, by these relations, induce the generation of affective and ethical values between producer and customer, and gradually the loyalty of exchange relationship and reproduction of solidarity, tending to a balance in terms of trade. The research concludes that these relationships, practices and values contribute incisively to support of the marketing strategies of the farmers surveyed.
\end{abstract}

Key-words: Family farming: markets; Social construction of markets; Theory of reciprocity; Mambai, Goiás. 


\section{LISTA DE FIGURAS}

Figura 1: Mapa de localização da APA Nascentes do Rio Vermelho..............15

Figura 2: Va. (à esquerda) e J. (à direita) .......................................................50

Figura 3: Ad. (a esquerda) vendendo por encomenda..................................55

Figura 4: Reunião de organização da feira..................................................

Figura 5: Nova feira do agricultor familiar de Mambaí......................................61

Figura 6: Va. e seus dois ajudantes na feira de Posse................................62

Figura 7: Derivados do pequi: polpa em conserva, óleo e castanhas............67

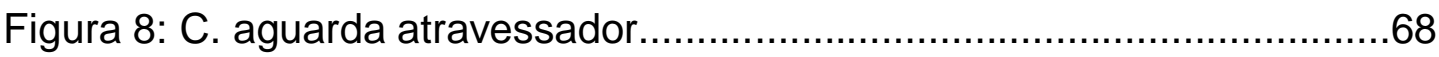

\section{LISTA DE TABELAS}

Tabela 1: Tipologia das formas comerciais e suas respectivas características

\section{LISTA DE GRÁFICOS}

Gráfico 1: Quantidade de agricultores que mobilizam cada forma comercial 


\section{LISTA DE SIGLAS}

ANVISA: Agencia Nacional de Vigilância Sanitária

APA: Área de Proteção Ambiental

APANRV: Área de Proteção Ambiental Nascentes do Rio Vermelho

APP: Área de Proteção Permanente

CAPES: Coordenação de Aperfeiçoamento de Pessoal de Nível Superior

CDS: Centro de Desenvolvimento Sustentável

CEASA: Central de Abastecimento do Distrito Federal

CIRAD: Centre de Recherche Agronomique pour le Développement

CMDRS: Conselho Municipal de Desenvolvimento Rural Sustentável

CONTAG: Confederação Nacional de Trabalhadores na Agricultura

CUT: Central Única dos Trabalhadores

DAP: Declaração de Aptidão ao PRONAF

DRP: Diagnóstico Rural Participativo

EMATER: Empresa de Assistência Técnica e Extensão Rural

FUNATURA: Fundação Pró-Natureza

IBAMA: Instituto do Meio Ambiente e Recursos Naturais

IBGE: Instituto Brasileiro de Geografia e Estatística

ICMBio: Instituto Chico Mendes de Conservação da Biodiversidade

INCRA: Instituto Nacional de Colonização e Reforma Agrária

ISPN: Instituto Sociedade População e Natureza

PA: Projeto de Assentamento

PAA: Programa de Aquisição de Alimentos

PNAE: Programa Nacional da Alimentação Escolar

PNRA: Plano Nacional de Reforma Agrária

PPP-Ecos: Programa Pequenos Projetos Eco-sociais

PROCERA: Programa de Crédito Especial para Reforma Agrária

PRONAF: Programa Nacional de Fortalecimento da Agricultura Familiar

MDA: Ministério do Desenvolvimento Agrário

MDS: Ministério do Desenvolvimento Social

ONG: Organização Não Governamental

ONU: Organização das Nações Unidas

SAF: Sistema agroflorestal

SEBRAI: Serviço de Apoio às Micro e Pequenas Empresas

SENAR: Serviço Nacional de Aprendizagem

UnB: Universidade de Brasília

UNESCO: Organização das Nações Unidas para a Educação, Ciência e Cultura 


\section{SUMÁRIO}

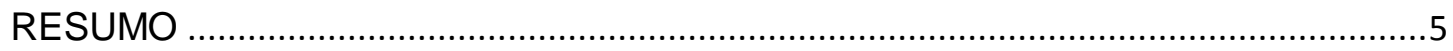

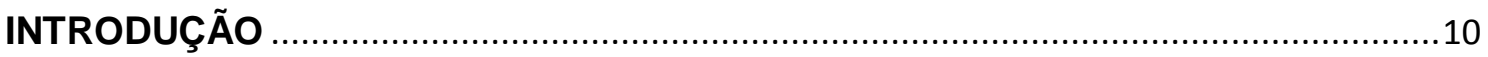

1. PROBLEMÁTICA, OBJETIVOS E CONTEXTO DA PESQUISA ….......................12

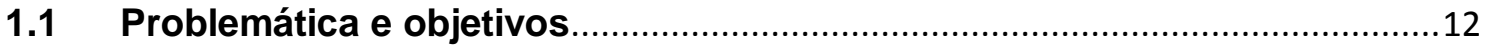

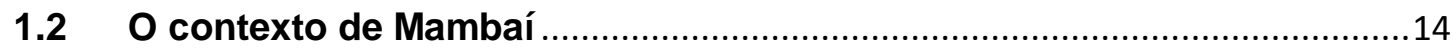

1.2.1 Os assentamentos rurais de Mambaí..........................................................17

2. REFERENCIAL TEÓRICO E METODOLOGIA DE PESQUISA …..........................20

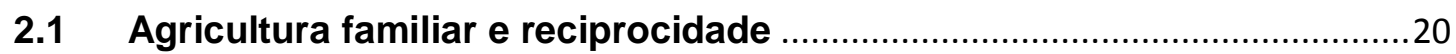

2.2 Antropologia econômica e teoria da reciprocidade ...................................24

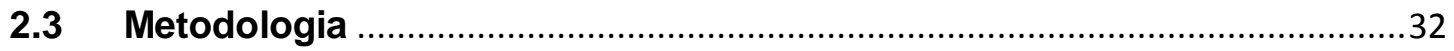

3 ESTRATÉGIAS COMERCIAIS E RELAÇÕES DE RECIPROCIDADE EM ASSENTAMENTOS RURAIS NO MUNICÍPIO DE MAMBAÍ ........................................39

3.1. Tipologia das formas de comercialização ….............................................. 41

3.2 Caracterização das formas de comercialização ..........................................48

3.2.1 Venda na rua e de porta em porta..............................................................48

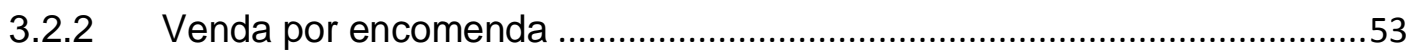

3.2.3 Venda na feira do agricultor familiar de Mambaí.........................................55

3.2.4 Venda no lote diretamente para o consumidor final.................................63

3.2.5 Venda do lote para intermediários e atravessadores ..............................64

3.2.5.1 Venda na meia: a reinvenção do intermediário .......................................70

3.2.6 Venda para pequenos mercados e supermercados ................................71

3.3 Articulação entre diferentes formas de comercialização ...........................74

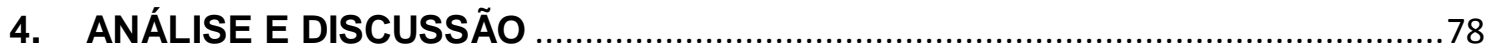

4.1 Relações de reciprocidade entre agricultores ............................................79

4.2 Relações de reciprocidade entre agricultores e consumidores .................84

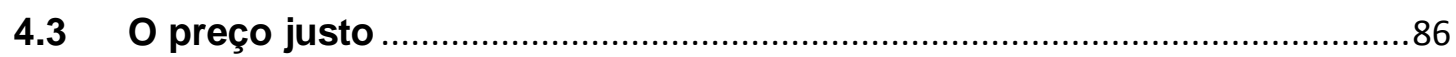

4.4 A construção social da nova feira de Mambaí …..........................................90

4.5 As relações de reciprocidade assimétricas e a exploração econômica na

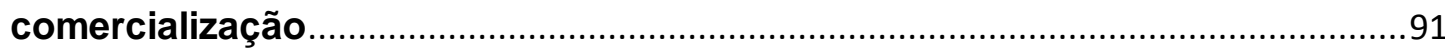

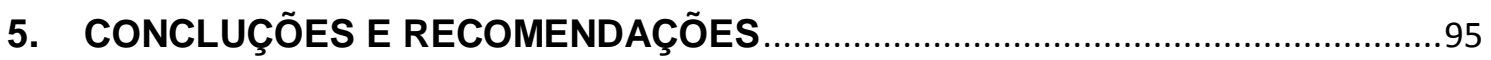

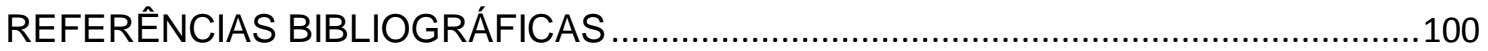




\section{INTRODUÇÃO}

A agricultura familiar é uma categoria social com expressiva representatividade em todo o território brasileiro. Segundo Frank Ellis (2000), esses agricultores perseguem diferentes estratégias, de resistência ou reação, para ampliar seus meios de vida e autonomia. Dentre estas estratégias está o desenvolvimento e a articulação de formas de comercialização sustentadas por mecanismos de ação coletiva e, sobretudo, por relações interpessoais de ajuda mútua e/ou de solidariedade. Os agricultores familiares assentados no município de Mambaí, no nordeste do estado de Goiás, promovem várias dessas formas comerciais fundamentadas na articulação flexível de relações de troca e reciprocidade.

A presente pesquisa se propõe analisar as relações socioeconômicas de solidariedade presentes no processo de construção social de mercados pelos agricultores familiares assentados em Mambaí e verificar o papel das mesmas na sustentação de cada estratégia comercial identificada, a partir da teoria da reciprocidade. Segundo Temple e Chabal (1995:01), “a reciprocidade vai além da simples permuta de bens, é um ato reflexivo entre sujeitos e, concomitantemente, uma relação intersubjetiva criadora de laços sociais".

A noção de reciprocidade, cuja gênese é oriunda da antropologia econômica, passou por diversas interpretações. Contudo, em linhas gerais, a teoria da reciprocidade renovada pela sociologia e antropologia econômica francesa pretende elucidar a natureza das diversas relações que compõem as relações humanas na vida econômica para além da visão pelo único prisma da troca mercantil (cálculo econômico), atualmente hegemônica. Apresentando-se de forma explícita ou implícita, essas relações de reciprocidade, também constituidoras das relações de mercado, são fundamentais na busca do crescente entendimento dos processos de construção de valores éticos na sociedade (SABOURIN, 2012a, NIEDERLE, 2014).

O estudo procura contribuir na análise e no entendimento das relações sociais associadas à comercialização de produtos de agricultores familiares 
assentados da reforma agrária, de acordo com os processos de construção social de mercados. O reconhecimento político, teórico e público das estratégias comerciais promovidas por agricultores familiares e as práticas, valores e relações sociais a elas vinculadas constitui um grande desafio na promoção de uma leitura do desenvolvimento rural que considere a complexidade sociocultural e econômica da agricultura familiar.

No Capítulo 1 apresentamos a problemática e os objetivos da pesquisa, e o contexto dos assentamentos rurais do município de Mambaí, localizado no interior da Área de Proteção Ambiental Nascentes do Rio Vermelho. Os referenciais teóricos e metodológicos da pesquisa são apresentados no Capítulo 2. O Capítulo 3 é dedicado à caracterização das formas de comercialização desenvolvidas por agricultores familiares assentados rurais em Mambaí e a descrição das relações de reciprocidade relacionadas às suas estratégias comerciais. No Capítulo 4 discutimos o papel das relações de reciprocidade na construção e sustentação das estratégias comerciais analisadas. Concluímos a presente dissertação apresentando considerações gerais e de cunho propositivo.

Em campo foram realizadas entrevistas semi-estruturadas com 43 famílias, constituídas por mulheres e homens, residentes nos seis assentamentos rurais de Mambaí, alcançando uma amostragem de 13,7\% de todas as 313 famílias registradas nos assentamentos. Posteriormente, selecionamos 12 famílias a serem entrevistadas de forma mais aprofundada, a partir de entrevistas abertas e observações participantes.

A presente pesquisa está inserida no Projeto Sociobiocerrado: Sociotechnical and Institutional Innovations for Conservation and Valorization of the Cerrado Biome. Este projeto é um convênio entre o Centro de Desenvolvimento Sustentável (CDS) da Universidade de Brasília (UnB) e o Centre de Recherche Agronomique pour le Développment (CIRAD) e é financiado pela Fundação Agropolis e pela CAPES. O objetivo do mesmo é apoiar pesquisas multidisciplinares envolvendo o desenvolvimento da agricultura familiar e seus produtos, buscando inovação, valorização e construção de mercados agroextrativistas conciliados à conservação do bioma Cerrado. 


\section{PROBLEMÁtICA, OBJETIVOS E CONTEXTO DA PESQUISA}

\subsection{Problemática e objetivos}

Os assentados rurais em Mambaí ou não recebem assistência técnica da EMATER (Empresa de Assistência Técnica e Extensão Rural) ou recebem uma assistência voltada à produção em monocultura de larga escala muitas vezes incompatível com os interesses dos próprios agricultores familiares e com suas capacidades logísticas e comerciais (AVELINE et al., 2015). Empenhando grandes esforços na agricultura de larga escala, muitos abandonam as tradicionais roças voltadas ao autoconsumo e às formas de comercialização localmente construídas. Ignoradas, estas formas comerciais são mantidas nas periferias das políticas públicas e projetos de desenvolvimento rural, guiados pela inclusão produtiva em grandes mercados de commodities como solução univalente. Porém, muitas famílias agricultoras assentadas em Mambaí têm se adaptado às novas condições políticas e econômicas, promovendo diferentes estratégias de acesso aos mercados locais e regionais, compatíveis com as suas práticas produtivas e comerciais, sustentadas por relações de solidariedade.

Nos assentamentos rurais de Mambaí foram observadas em campo diversas formas de comercialização de produtos agrícolas onde eram mobilizadas práticas sociais de solidariedade e ajuda mútua fundadas em relações de reciprocidade. Contudo, cabe entender como ocorre a construção social dessas diversas formas de comercialização e qual é o papel das relações de reciprocidade na sustentação destas diferentes relações de mercado.

Partimos da hipótese de que os agricultores assentados em Mambaí, alguns muito isolados e praticamente sem acesso às políticas públicas e programas do governo, reproduzem diferentes estratégias comerciais construídas cotidianamente a partir de relações sociais de proximidade entre produtores, comerciantes, consumidores e outros atores sociais. Em segundo 
lugar, conjecturamos a existência de um papel singular das relações de reciprocidade (no sentido de solidariedade) na constituição dessas estratégias comerciais, mesmo sendo a troca mercantil o principal objeto dessas relações econômicas. Por último, consideramos que estas relações de reciprocidade são reproduzidas cotidianamente pelos agricultores, contribuindo na constituição e sustentação de suas práticas comerciais e conferindo coesão e resiliência ${ }^{1}$ ao processo de construção social de mercados.

Com a finalidade de verificar estas hipóteses, a pesquisa tem por objetivo geral analisar o papel das relações sociais de reciprocidade na construção e sustentação das estratégias comerciais de agricultores familiares assentados em Mambaí.

Os objetivos específicos se desdobram em:

1) Identificar e caracterizar as diversas formas de comercialização de produtos agropecuários e extrativistas socialmente construídas por agricultores familiares dos assentamentos de Mambaí;

2) Caracterizar as relações de reciprocidade associadas às principais formas de comercialização e analisar o papel dessas relações na construção e sustentação dos mercados desses atores sociais.

\footnotetext{
${ }^{1}$ Resiliência é um termo oriundo do latim resiliens e significa a capacidade de voltar ao estado normal diante de uma perturbação ou dificuldade.
} 


\subsection{O contexto de Mambaí}

Mambaí foi oficializado como município em 1958. Seu nome é oriundo das palavras mangaba e Bahia. A mangabeira é uma planta nativa do cerrado e dela se fazia a extração do látex, que por muito, tempo sustentou o comércio local. E "Baí" devido à cidade se localizar na fronteira com o estado da Bahia. Segundo estimativas do IBGE em 2015, a população do município era de 7945 habitantes, tendo um aumento de $15,6 \%$ desde 2010 , quando o censo contabilizou 6871 habitantes (Diário Oficial da União, em 28 de agosto de 2015).

Mambaí, Damianópolis e parte dos municípios de Posse e Buritinópolis estão dentro da Área de Proteção Ambiental Nascentes do Rio Vermelho (APANRV). A sede da administração desta unidade de conservação, assim como os escritórios do ICMBio e da EMATER, estão no centro da cidade de Mambaí. Esta está situada no nordeste do estado de Goiás, a uma distância de 511 quilômetros da capital, Goiânia, e a 308 quilômetros da capital do país, Brasília.

A Área de Proteção Ambiental (APA) Nascentes do Rio Vermelho foi instituída pelo Decreto s/n. ${ }^{\circ}$ de 27 de setembro de 2001 e incorporou muitas áreas agrícolas, incluindo grandes fazendas, pequenas e médias propriedades e os próprios assentamentos rurais aqui estudados. Com a delimitação da APA, houve um aumento da fiscalização por parte dos órgãos ambientais frente a algumas práticas consideradas ilegais (por exemplo: agricultura de corte-equeima, roças em veredas e pecuária extensiva), principalmente por estarem em desacordo com o Código Florestal e com a Lei de Crimes Ambientais de 1998. Esta situação impactou fortemente a agricultura de subsistência praticada e intensificou a pobreza local ${ }^{2}$. Muitos agricultores foram obrigados a vender sua mão de obra fora da propriedade e se estabeleceu uma relação conflituosa entre os agricultores da região e as autoridades protetoras do meio

\footnotetext{
${ }^{2}$ Esta situação obrigou as comunidades locais a plantarem em lugares mais altos longe dos rios, locais secos de cerrado. Quando o agricultor tinha acesso à água encanada, privilégio de poucos, esta não era suficiente para irrigação. As terras secas de cerrado só têm valor para a lavoura de mandioca e a alimentação de animais soltos.
} 
ambiente, principalmente nos assentamentos da reforma agrária presentes na região (ELOY; LUDEWIGS, 2013; BAUSGIRAUD, 2013).

\section{Mapa de Localização da APA das Nascentes do Rio Vermelho}
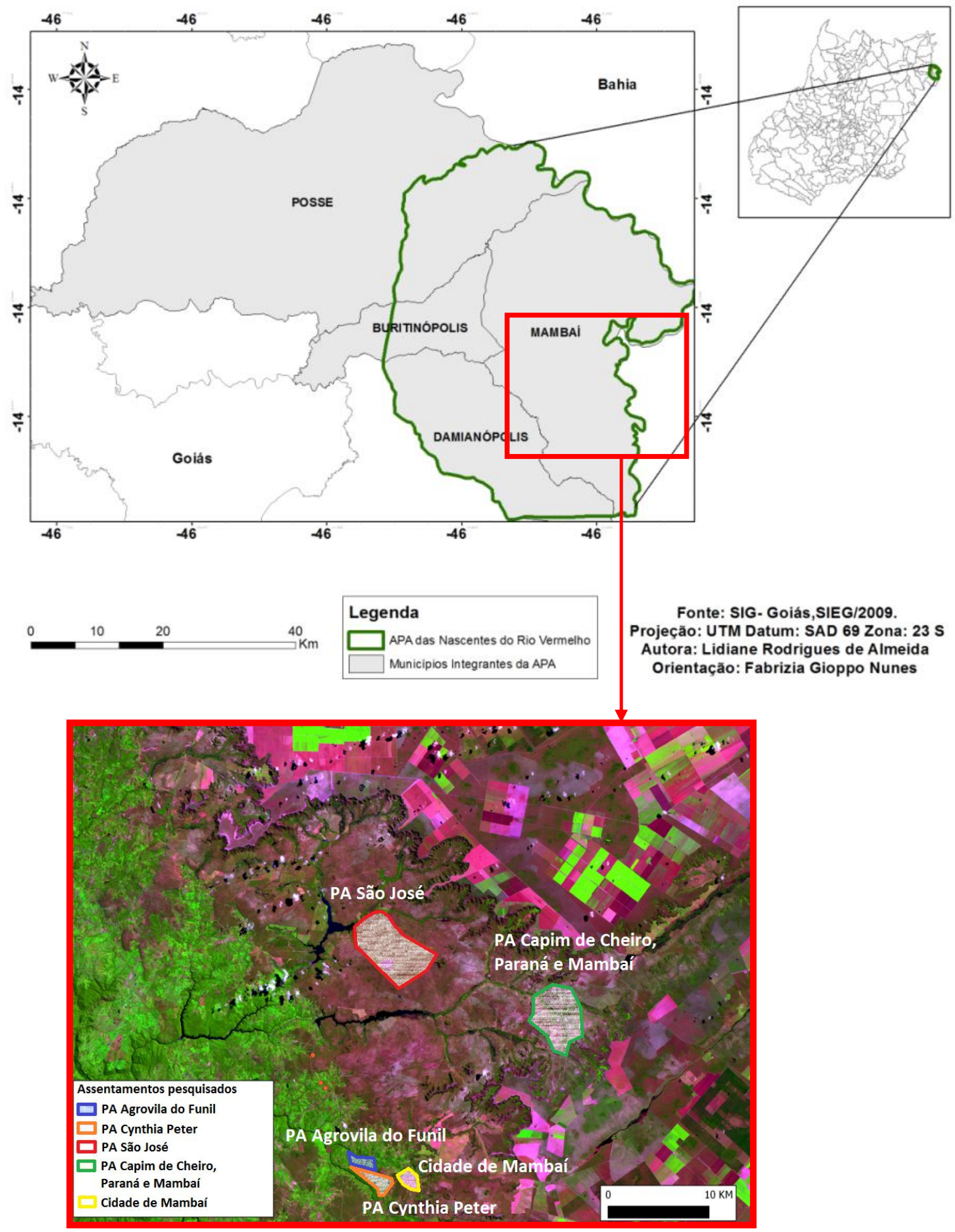

Figura 1 - Mapa de localização da APA Nascentes do Rio Vermelho 
Segundo Lúcio, Eloy e Ludewigs (2013), as práticas tradicionais de uso dos recursos naturais cerratenses ${ }^{3}$ são consideradas, muitas vezes, incompatíveis com os objetivos de conservação. Por outro lado, as atividades consideradas sustentáveis do ponto de vista ambiental e social (por exemplo: extrativismo), ainda possuem dificuldade em alcançar escala e autonomia suficientes para serem consideradas como economicamente viáveis pelos agricultores locais, frente às oportunidades trazidas pelo avanço do agronegócio. A região do Nordeste de Goiás é representativa destas dinâmicas, mas ainda é constituída por áreas de Cerrado com extensos remanescentes de vegetação nativa. Por estar situada no cruzamento entre o norte de Peruaçu, a Chapada dos Veadeiros e o Jalapão, ela tem uma importância central para a conservação da biodiversidade no bioma como um todo (ELOY; LUDEWIGS, 2013).

A histórica forma de atuação de órgãos ambientais baseada no "comando e controle", segundo os próprios gestores da APANRV ${ }^{4}$, dificulta a relação do atual órgão gestor (ICMBio) com os moradores assentados, dificultando a elaboração e a execução de políticas de conservação. O ICMBio tem buscado conhecer a realidade dos assentamentos e, assim, propor estratégias mais integradas de desenvolvimento rural, que obtenham maior resultado econômico com o Cerrado em pé. Desta forma, segundo gestores da APANRV, o órgão busca cumprir sua missão institucional de "proteger o meio ambiente e promover o desenvolvimento socioambiental" estruturando relações de parceria com as comunidades que residem dentro da APA. Esta forma de atuação foi constatada em campo e a partir de relatos de agricultores e executores de projetos de desenvolvimento local, como as organizações Fundação Pró-Natureza (Funatura) e ONG Mutirão Agroflorestal.

As riquezas naturais e especificidades territoriais locais têm impulsionado o ecoturismo na região. Segundo a secretária de turismo da prefeitura de Mambaí ${ }^{5}$ o ecoturismo tem se mostrado como uma das principais "vocações" do município. A atividade turística tem incrementando o

\footnotetext{
3 "Cerratense" é uma palavra criada pelo historiador e poeta Paulo Bertran para denominar quem nasceu ou quem adotou como "sua" a região do cerrado (BERTRAN, 1998).

${ }^{4}$ Entrevista concedida em 12 de abril de 2015, por Eduardo Barroso, então vice-gestor da APANRV.

${ }^{5}$ Entrevista concedida em 14 de novembro de 2015.
} 
desenvolvimento socioeconômico local, abundante em cavernas, cachoeiras, rochedos e paredões excelentes para a prática de esportes radicais.

\subsubsection{Os assentamentos rurais de Mambaí}

Os seis assentamentos rurais de Mambaí possuem realidades muito diferentes. Existem assentamentos próximos ao centro urbano da cidade, assentamentos distando mais de 30 quilômetros de estrada de terra da cidade e outro mais próximo do município vizinho, Posse. Esta multiplicidade de condições sociais, econômicas e políticas, como diferentes condições de acesso à assistência técnica e recursos públicos e ambientais, torna a presente pesquisa rica em detalhes.

Segundo Sabourin (2009), dois fatores são particularmente impactantes na precarização e no aumento da dependência de camponeses, pequenos agricultores e suas organizações: a desestruturação econômica pela crise dos mercados de produtos tradicionalmente comercializados e a reinstalação de agricultores em novas localidades, como no caso dos assentamentos de reforma agrária, perímetros irrigados ou deslocamento por conta da construção de barragens. Os agricultores dos projetos de assentamento (PAs) de Mambaí (PAs São José, Cynthia Peter, Agrovila do Funil, Mambaí, Capim de Cheiro e Paraná) possuem históricos e experiências similares: as famílias foram deslocadas de seus locais de origem para serem assentadas pelo INCRA no marco da reforma agrária e passaram depois pela experiência de fracassos sucessivos de diferentes ciclos comerciais estimulados por agentes externos.

A soja e o algodão são produzidos por grandes fazendas monocultoras no oeste do estado da Bahia, localizadas em áreas planas acima da chapada, muito próximas dos assentamentos e da cidade de Mambaí. Esta produção monocultora tornou Mambaí cidade dormitório de muitos caminhoneiros e trabalhadores técnicos das grandes fazendas. Muitos assentados dividem seu trabalho no lote com trabalhos fixos ou diárias como "boias frias" para complementar a renda familiar nestas fazendas.

O Projeto de Assentamento Agrovila do Funil está situado próximo da sede do município de Mambaí e foi criado em 1999 por meio do programa 
Banco da Terra. Também conhecido como PA Funil, o assentamento é formado por 45 lotes de 10 a 15 hectares situados na Fazenda do Funil, desapropriada e adquirida pelo banco em 2000. O PA Funil possui Reserva Legal coletiva vizinha à reserva legal do PA Cynthia Peter, formando uma área contínua.

Instituído pelo INCRA em 2004 na antiga Fazenda Atoleiro, localizada a 1,6 Km da sede municipal de Mambaí, o PA Cynthia Peter reúne 41 famílias com lotes de aproximadamente 10 hectares. Esse assentamento, diferente dos demais, foi estabelecido após a criação da APA Nascentes do Rio Vermelho. A associação do PA Cynthia Peter está se mostrando a mais ativa das associações de agricultores assentados de Mambaí. Esta associação, em parceria com o ICMBio e o Centro de Desenvolvimento Sustentável da Universidade de Brasília (CDS-UnB), está executando um projeto financiado pelo Programa de Pequenos Projetos Ecossocais (PPP-ECOS) do Instituto Sociedade População e Natureza (ISPN). O mesmo está em andamento e é voltado à implementação de sistemas agroflorestais (SAF).

O PA São José possui apenas 17 parcelas, com média de 75 ha e está situado entre as sedes dos municípios de Posse e Mambaí, com uma localização estratégica entre dois importantes centros consumidores. Os PAs Capim de Cheiro, Mambaí e Paraná estão localizados próximos à divisa com o Estado da Bahia e estão mais isolados, ficando à uma distância de 30 quilômetros de estrada de terra da sede do município.

Os assentamentos rurais de Mambaí enfrentam problemas comuns a muitos PAs brasileiros: pouca produtividade, baixa renda, falta de assistência técnica, abandono de lotes, êxodo da juventude e degradação ambiental. No passado foram executadas tentativas frustradas de implementação de projetos de infra-estrutura e inclusão produtiva nestes assentamentos, como 0 financiado pelo INCRA e pelo Programa de Crédito Especial para Reforma Agrária (PROCERA). Os limites ou os fracassos desses projetos são responsáveis pela descrença e desconfiança, por parte dos agricultores e outros assentados, em relação a políticas e programas públicos. Em muitos casos os usuários contraíram dívidas perante o banco e perderam o direito de 
acesso ao crédito, sem terem alcançado nenhum dos benefícios almejados. Segundo relatos de assentados e representantes públicos ${ }^{6}$, o fracasso desses projetos foi consequência da falta de planejamento e assistência técnica continuada das entidades executoras (INCRA, MDA, MDS etc) e a falta de envolvimento dos próprios assentados nos projetos.

A falta de assistência técnica especializada e compromissada com as especificidades locais, em particular em termos de valorização da produção e do extrativismo, dificulta o fortalecimento das comunidades e de suas estratégias comerciais. Os solos arenosos com baixa fertilidade da região e a alta susceptibilidade a erosão e a lixiviação tornam insustentáveis práticas agrícolas convencionais, tornando a produção inviável em poucos anos. $O$ êxodo rural e a falta de perspectiva dos jovens nos assentamentos são problemas graves. De acordo com o ICMBio, a EMATER-GO e o relatório de campo da disciplina Agricultura, Conservação e Desenvolvimento Rural Sustentável na Amazônia e Cerrado (ELOY et LUDEWIGS, 2013), do Programa de Pós-graduação em Desenvolvimento Sustentável - UnB, o fortalecimento e a valorização da produção e comercialização de produtos agrícolas e extrativistas (alimentícios ou não) oriundos do Cerrado e da agricultura familiar se apresentam com potencial significativo de geração de renda e manutenção dos jovens nos assentamentos.

\footnotetext{
${ }^{6}$ Técnico da EMATER-GO, entrevista concedida em 07 de novembro de 2015; M. S., agente da secretaria de saúde de Mambaí, entrevista concedida em 28 de outubro de 2015; J. B. agricultor e comerciante, entrevista concedida em 27 de janeiro de 2016. Todos concederam depoimentos com opiniões coincidentes.
} 


\section{REFERENCIAL TEÓRICO E METODOLOGIA DE PESQUISA}

\subsection{Agricultura familiar e reciprocidade}

A agricultura de pequeno porte é largamente referida como economicamente estagnada e politicamente inerte, formando uma massa homóloga, invisível politicamente (NETTING, 1993). Um vasto setor da sociedade brasileira concebe a pequena agricultura de base familiar em processo de extinção. A atividade agrícola seria fadada à contínua e crescente industrialização e divisão social do trabalho. Contudo, essa agricultura camponesa e familiar esteve presente desde os primórdios das civilizações humanas, sendo causa e consequência do fim do nomadismo e início das cidades. Resistindo ao processo de industrialização monocultora de larga escala impulsionado pelos governos neoliberais durante a revolução verde, a agricultura de pequeno porte fundada no núcleo familiar se mantém participando de boa parte das economias ocidentais e orientais por meio de distintas práticas diversificadas de produção e comercialização.

Historicamente, no Brasil, os pequenos agricultores foram desconsiderados como categoria social (QUEIROZ, 1963) e ignorados pelos projetos de desenvolvimento até a segunda metade do século XX. Nos anos 50 surgem os primeiros sindicatos e Ligas Camponesas reivindicando direitos e acesso a terra pela reforma agrária. A necessidade da redistribuição fundiária, inquestionável em um país ainda fundado sobre o grande latifúndio, torna-se política durante o regime militar sob o viés da colonização: ocupação dos vastos territórios desabitados no interior do país. Foi com a adoção do Plano Nacional de Reforma Agrária (PNRA) em 1985 e com a nova constituição de 1988 que a redistribuição fundiária passa a ser implementada a partir da desapropriação de terras particulares, muitas delas sem uso por serem pouco adequadas à agricultura, para tornarem-se "assentamentos" rurais (SPAROVEK, 2003). Esses assentamentos são divididos em lotes distribuídos entre famílias para fins de produção agropecuária, como no caso dos assentamentos estudados pela presente pesquisa. 
O conceito de agricultura familiar surge durante os anos de $1980 \mathrm{com} o$ intuito de resignificar parte daquela pequena agricultura (taxada como improdutiva) e de distingui-la dos preceitos do grande agronegócio industrial. Impulsionado pela pressão de movimentos sociais e sindicais rurais (CONTAG e CUT), a agricultura familiar alcançou reconhecimento político e ganhou força no campo científico e acadêmico por meio de importante volume de trabalhos científicos, técnicos e institucionais, desenvolvidos no Brasil e em outros países, principalmente na Europa (DUARTE, 2014). Essa categoria social se tornou foco de políticas públicas em 1995 após a institucionalização da primeira política nacional voltada ao setor agrícola de caráter familiar, o PRONAF (DUARTE, idem).

Hoje, agricultores familiares são, segundo a Lei 11.326 de 24 de julho de 2006 (Lei da Agricultura Familiar), aqueles que: i) praticam atividades no meio rural; ii) não detenham área maior que 4 (quatro) módulos fiscais; iii) utilizem predominantemente mão de obra da própria família em suas atividades econômicas; iv) tenham renda predominantemente originada de atividades vinculadas ao seu estabelecimento ou empreendimento e v) dirijam seu estabelecimento ou empreendimento a partir do trabalho familiar.

Desde os anos 2000, existiu a crescente diversificação de políticas e o aumento dos financiamentos públicos para o setor da agricultura familiar. Contudo, essas políticas possuem verbas reduzidas se comparadas com os investimentos voltados para o agronegócio patronal que costuma reproduzir no país um modelo monocultor, gerando exclusão social e concentração de renda no campo (MATTEI, 2014) Ainda, aquela histórica visão da agricultura de pequeno porte familiar como fadada ao desaparecimento leva, segundo Sabourin (2011), à consolidação de políticas públicas de caráter social ou compensatório por meio da transferência de renda (como o programa bolsa família). O tratamento social promovido por essas políticas tende a desviar o foco da consolidação da agricultura familiar enquanto categoria social produtiva, ativa política e economicamente no país.

Contrariando aquela visão limitada da agricultura familiar, as estatísticas dos censos agropecuários do Instituto Brasileiro de Geografia e Estatística 
(IBGE) e dos dados atualizados do Ministério do Desenvolvimento Agrário (MDA) mostram claramente a importância produtiva da agricultura familiar no contexto social e econômico do país. Os dados do Censo Agropecuário de 2006 esclarecem que o setor da agricultura familiar produz $87 \%$ da produção nacional de mandioca, $70 \%$ da produção de feijão, $46 \%$ do milho, $34 \%$ do arroz e $58 \%$ do leite, itens alimentícios entre os mais consumidos no país (IBGE, 2009). Vale destacar que esses dados são estatisticamente incompletos por não considerarem o autoconsumo, o intraconsumo e as trocas não mercantis entre agricultores e outros indivíduos, nem muitas vezes, a comercialização local não sujeita ao Imposto sobre Circulação de Mercadorias e Serviços.

Maria Isaura de Queiroz, em 1963, já questionava a não contabilização da produção agropecuária dos pequenos agricultores em seu livro Uma Categoria Rural Esquecida. No caso citado pela autora, “(...) a produção reconhecidamente existente, oficial de Minas Gerais, só alimentaria $53 \%$ da população total (...)" (QUEIROZ, 1963: 60). Ou seja, 47\% da produção, usada para o autoconsumo e em trocas informais, tinha sua relevância econômica ignorada pelo poder público, denominada 'agricultura de subsistência'.

A dicotomização entre diferentes agriculturas (comercial/de subsistência) como categorias opostas e antagônicas existiu desde o descobrimento do Brasil, mas se intensifica a partir da revolução verde, nos anos 70 , por grandes políticas de modernização da agricultura. Essas políticas foram baseadas em tecnologias de produção em larga escala voltadas aos mercados das grandes commodities internacionais e disseminam até hoje "discurso sobre competitividade como referência ideológica e mecanismo econômico (...). Tal processo introduz/altera, na ótica dos produtores, os conceitos de trabalho e de competitividade (...) de qualidade e de produtividade, cujos impactos interferem na reelaboração da identidade socioprofissional" (GEHLEN, 2004: 96).

Essa ótica impõe aos agricultores práticas cotidianas guiadas pela maximização da produção voltada para mercados e commodities agrícolas e o acúmulo de capital. Essa lógica, muitas vezes externa ao interesse do(a)s agricultor(a)s familiares, causa dependência econômica e política e a 
progressiva externalização ${ }^{7}$ de sua produção e comercialização. Porém, segundo Niederle (2007), essa crescente mercantilização da vida no campo não conseguiu impor uma dependência completa dos agricultores e tampouco orientar suas relações e práticas segundo um modelo linear de desenvolvimento capitalista. Ploeg (2008) defende ainda que, apesar do contexto desfavorável, aquela pequena agricultura local de caráter familiar conseguiu diversificar suas formas de produção e comercialização e manter práticas tradicionais distintas daquelas orientadas unicamente pela lógica de mercado.

A agricultura familiar é responsável por incrementar a diversidade e consolidar distintos estilos de agricultura (PLOEG, 2008) constituídos por relações que ultrapassam as fronteiras de um sistema econômico fundado majoritariamente pelo interesse monetário interessado, próprio do capitalismo mercantil. Antônio Candido (1964), em seu livro As Formas de Solidariedade, abordava as relações de ajuda mútua e solidariedade que constituíam, na sua época, as práticas cotidianas dos agricultores brasileiros no campo:

A necessidade de ajuda (...) e a retribuição automática determinavam a formação duma rede ampla de relações, ligando os habitantes do grupo de vizinhança uns aos outros e contribuindo para a sua unidade estrutural e funcional (CANDIDO, 1964: 194).

As relações de solidariedade ou de reciprocidade envolvem tanto elementos sociais e culturais como econômicos e produtivos. No caso da agricultura familiar caracterizam praticas econômicas inseridas ou associadas a laços sociais e afetivos.

Para MARGARIDO (apud SABOURIN, 2011:49) a reciprocidade é constituída por "relações de parentesco e de prestações recíprocas simétricas

\footnotetext{
${ }^{7}$ A externalização, segundo Ploeg (1992), é o processo de aumento da dependência de agricultores em relação a recursos controlados por outros atores envolvidos numa cadeia de produção e comercialização externos, como o poder público e financiadores privados.
} 
de alimentos ou de trabalho, geralmente interpretadas em termos de dádivas/contra dádivas".

O foco analítico sobre as relações de reciprocidade em mercados tem sido majoritariamente desenvolvido por estudos de economia solidária. Esses se baseiam na ideia de que o comportamento econômico pode ser regido por diferentes princípios, dentre eles a reciprocidade e a redistribuição. Contudo, muitos de seus teóricos afirmam que esses princípios têm sido corrompidos pela lógica capitalista de mercado e destacam a importância de resgata-los no intuito de fortalecer um sistema econômico mais justo (BERTUCCI, 2010). Longe de querer deslegitimar pura e simplesmente a troca mercantil e a lógica da maximização do lucro individual, o que seria incongruente e irracional, a presente pesquisa busca destacar as distintas relações que constituem os mercados com foco no papel da reciprocidade na sustentação das formas comerciais de origem camponesas e na reprodução da agricultura familiar enquanto categoria social.

\subsection{Antropologia econômica e teoria da reciprocidade}

Os teóricos da antropologia e da sociologia econômica procuram superar as abordagens da economia neoclássica em que as dinâmicas de mercado são tratadas por uma visão utilitarista das relações comerciais baseada no individualismo metodológico. A economia neoclássica trata os aspectos econômicos como uma entidade externa à sociedade, distante da vida social, afastando-se da análise de suas instituições. Segundo Mark Granovetter (2007), um dos inspiradores da nova sociologia econômica, nem a economia tradicional está totalmente desprovida do cálculo interessado, nem a economia moderna está isenta de ingerência social. Granovetter capta em suas pesquisas a mediação do econômico pelo social e consolida a noção de "construção social de mercados", em que as formas de funcionamento dos mercados são diretamente relacionadas com os tipos de redes sociais em que estão inseridos (WILKINSON, 2002). Granovetter (2005) considerou a ação 
econômica como um tipo de ação social e suas instituições como construções sociais resultado de relações e acordos socialmente situados.

A reciprocidade, na antropologia, se origina da tentativa de desvendar as relações através das quais os homens fazem circular entre si coisas e serviços. Analisar mercados e suas dinâmicas pressupõe fundamentalmente analisar relações de troca e reciprocidade entre atores (agricultores, comerciantes, associações, ONGs, instituições públicas etc.). Sendo assim, a presente pesquisa considera cada forma específica de fazer circular mercadorias, mediada pelo câmbio monetário, uma "forma comercial" (ex. venda direta de porta em porta, venda na feira, venda para atravessadores). A articulação entre essas formas comerciais e as relações de reciprocidade e troca a elas relacionadas denominamos "mercados", no plural, pois são fenômenos localizados no tempo e no espaço e resultado da ação humana, indissociáveis de suas particularidades.

Essa abordagem plural da economia tem origem na teoria de Karl Polanyi em seu livro clássico, A Grande Transformação, publicado originalmente em 1944. O autor argumenta que a economia, antes da modernidade (consolidada pela revolução industrial e desenvolvimento do capitalismo), se constituía a partir das regras e costumes dos sistemas de valores das sociedades, que não se confundiam com os mercados. A economia era um aspecto da vida onde a organização das trocas materiais era subordinada a sistemas sociais e econômicos fundados na reciprocidade e na redistribuição (POLANYI, 2000).

Polanyi (2000) distinguiu três diferentes formas de economia ou de "integração social": a troca, a reciprocidade e a redistribuição ${ }^{8}$. Porém, Polanyi sustenta a ideia de que a economia da reciprocidade depende de estruturas e instituições sociais especificas para ser reproduzida e que ela, enquanto forma econômica, desapareceria com o desenvolvimento do capitalismo, onde a troca

\footnotetext{
${ }^{8}$ A redistribuição se constitui como uma forma de transação econômica em que existe uma apropriação por um centro e uma subsequente redistribuição dos bens materiais e simbólicos para outros participantes exteriores. Na redistribuição existe um centro mobilizador que concentra e redistribui (POLANYI, 2000).
} 
mercantil se generaliza segundo o fenômeno do mercado auto-regulador ${ }^{9}$ (WILKINSON, 2002).

Para Polanyi, como o desenvolvimento da sociedade capitalista, a dimensão econômica seria "desenraizada" de seu contexto social, ao contrário de antes que a econômica estava "imersa" (embeddedness) nas relações e redes sociais. Essa perspectiva de imersão da economia nas relações sociais foi uma das maiores contribuições de Polanyi à teoria social, revisitada por Granovetter no artigo Economic Action and Social Structure: the problem of embeddednes (1985).

Granovetter, precursor da Nova Sociologia Econômica, retoma a discussão analisando exatamente a influência das relações sociais sobre os comportamentos e instituições nos mercados, chegando à conclusão de que os indivíduos não agem nem de maneira totalmente autônoma nem de maneira totalmente mecânica e impotente, nem nas sociedades pré-mercantis nem nas sociedades de mercado.

Localizar a ação (individual e institucional) no contexto social considerando sua história segundo a visão dos fenômenos construídos socialmente são fortes traços da sociologia econômica inaugurada por Granovetter. O termo "construção social de mercados" foi formalizada por Arnaldo Bagnasco (1988) em sua obra La Construzione Sociale del Mercato, demonstrando como fatores históricos e culturais e laços e valores sociais (ex. laços de confiança e valores éticos) interferem no desenvolvimento dos mercados na sociedade moderna.

$\mathrm{Na}$ antropologia, Marcel Mauss, em 1961, procurando caracterizar no Ensaio sobre a Dádiva (2003) as origens da troca nos povos indígenas e nas civilizações antigas, identifica nas prestações socioeconômicas dessas sociedades, uma norma constante que ele qualifica como a "tríplice obrigação de dar, receber e retribuir". Segundo Mauss, essas três obrigações universais são geradas e estruturadas pelo que chamou de relações de dádiva e contradádiva. Mauss (idem) qualificou a reciprocidade das dádivas como uma força

\footnotetext{
9 Para Polanyi, no desenvolvimento do capitalismo surge o fenômeno do mercado auto-regulador provocado pela liberação dos inputs terra, trabalho e dinheiro, tornando-os "mercadorias fictícias" e provocando uma total ingerência social, podendo levar a uma implosão social (WILKINSON, 2008).
} 
espiritual entre indivíduos capaz de criar laços afetivos, éticos ou espirituais no ato de trocas materiais ou imateriais, estruturando assim relações sociais e transações econômicas reguladas por essa tríplice obrigação.

O pensamento de Mauss permitiu que Lévi-Strauss teorizasse sobre a reciprocidade, enquadrando a mesma como uma estrutura elementar universal do parentesco. A universalidade da tríplice obrigação formulada por Mauss ensejou Dominique Temple $(1997,2003)$ a propor o princípio da reciprocidade como matriz das relações humanas, presentes em todas as sociedades, précapitalistas ou capitalistas (SABOURIN, 2008).

Existe uma tendência a confundir troca e reciprocidade. O próprio LéviStrauss tem contribuído para essa confusão associando reciprocidade a uma troca recíproca simétrica. Segundo Polanyi (2000), a reciprocidade é uma categoria econômica diferente da troca. A reciprocidade envolve a preocupação com as necessidades do outro quando a troca mercantil procura, mediante um pagamento, livrar-se de toda divida social com o outro (TEMPLE, 1998).

Sabourin (2012a) sugere distinguirmos teoricamente o termo "troca" de "reciprocidade", pois aquele se apresenta de forma polissêmica e é muito usado no senso comum e acadêmico (principalmente na economia) com o significado de "diferentes modos de transferência de bens e serviços realizados mediante contrapartidas ou equivalência entre uns e outros" (SABOURIN, 2012a:56).

Necessitamos da noção e do princípio de reciprocidade, precisamente para caracterizar relações e prestações que não impliquem a noção de cálculo (interessado) ou que não privilegiem apenas a satisfação de interesses materiais privados que correspondem bem ao espírito do princípio da troca (SABOURIN, 2012a: 56).

A importância dessa distinção é ainda dar ênfase às diversas relações que permeiam e sustentam prática e simbolicamente as próprias relações de trocas (como simples permuta de bens e serviços), configurando sistemas híbridos onde as relações de troca e de reciprocidade coabitam. O princípio 
econômico da reciprocidade permeia justamente a preocupação com o próximo e os membros da coletividade humana.

Mireille Chabal (2005) chama a atenção para a existência de três formas de reciprocidade: positiva, negativa e simétrica. A forma positiva é aquela que corresponde a lógica da dádiva, que tende a estabelecer um vínculo social entre duas partes no sentido de uma inclusão do outro. Essa é reconhecida na antropologia como a "reciprocidade da dádiva" que segundo Temple pode ser um motor da produção:

O desejo de ser cada vez mais prestigiado socialmente (pela lógica da reciprocidade) obriga os atores a buscarem sempre retribuir (contra-dádiva) mais do que ele recebeu (dádiva), portanto a produzir mais. A dialética da reciprocidade cria sem cessar abundância para a coletividade (TEMPLE, 2005: 01, tradução livre).

A forma negativa da reciprocidade, segundo Chabal (2005), também estabelece um vínculo social, mas um vínculo negativo, ou seja, que promove a exclusão do outro, a oposição entre as partes. "O princípio da reciprocidade funciona também para fazer a guerra ou fazer respeitar a honra e os direitos" (SABOURIN, 2011: 49). Conhecida como reciprocidade da vingança, essa forma negativa da reciprocidade não necessariamente opõe as partes, pois é justamente na diferenciação que existe a possibilidade da união.

A reciprocidade simétrica estabelece uma paridade entre os envolvidos de uma relação, cada um dá ao outro sem buscar submetê-lo, sem obriga-lo a nada (CHABAL apud SABOURIN, 2009). A reciprocidade simétrica não envolve necessariamente uma igualdade na distribuição das dádivas (imaterial) e dos próprios bens materiais constituintes da troca e seus estimados valores socialmente construídos. A simetria da reciprocidade envolve a "justiça", ou seja, uma redistribuição em função dos méritos de cada um (SABOURIN, 2009).

As relações de reciprocidade podem ser também categorizadas segundo suas estruturas relacionais, segundo o número, a posição e o estatuto de seus diversos participantes (CHABAL, 2005). Se repetidas e institucionalizadas, as 
relações de reciprocidade podem ser analisadas como estruturas elementares de reciprocidade.

As estruturas elementares de reciprocidade foram sistematizadas por Temple, em 1998, identificando sentimentos e valores humanos relacionados e produzidos por cada tipo de estrutura de reciprocidade. Assim, segundo Temple $(1998,2003)$ as principais estruturas elementares de reciprocidade são: a reciprocidade binária (entre dois indivíduos ou dois grupos); a reciprocidade ternária (envolvendo pelo menos três sujeitos); a reciprocidade centralizada (que corresponde a redistribuição de Polanyi) e a reciprocidade generalizada.

As relações estruturadas mais correntes nas sociedades e comunidades rurais hoje são a binária e a ternária. As relações de reciprocidade binária podem ser divididas entre dois subtipos:

- A relação estruturada "cara a cara" corresponde a estrutura da aliança: familiar no caso do parentesco (casal) ou produtiva no caso da ajuda mútua. Muitas vezes nas sociedades camponesas a ajuda mútua dá lugar ao compadrio, que corresponde a uma forma de extensão simbólica do parentesco.

A orientação da relação "cara a cara" pode ser simétrica, gerando sentimento de amizade ou assimétrica, podendo gerar prestígio do doador e a submissão ou obrigação do donatário.

- A relação estruturada de compartilhamento ou de partilha corresponde a uma relação bilateral entre um individuo e o conjunto do grupo. O lema é "um por todos, todos por um". Essa relação estruturada corresponde, por exemplo, a figura do manejo de bens ou recursos comuns ou coletivos na agricultura: terras, floresta, pastagens, água, equipamentos, conhecimentos etc. A especificidade dessa relação quando simétrica é de gerar o sentimento de confiança.

As relações estruturadas ternárias envolvem ao menos três partes. Ela pode ser unilateral (por exemplo, no caso da dádiva intergeracional, gerando 0 
sentimento de responsabilidade) ou bilateral, quando a prestação funciona entre todos nos dois sentidos, gerando o sentimento de justiça.

Sendo assim, as relações estruturadas de reciprocidade podem ser identificadas e analisadas na busca do entendimento dos processos de produção e reprodução de valores afetivos e éticos no grupo social, na comunidade ou sociedade. As estratégias econômicas de agricultores familiares e respectivas relações sociais (comerciais ou não) são permeadas por relações de troca e de reciprocidade, em que ambas as relações possuem papéis particulares e geram valores materiais e instrumentais de um lado e valores sociais, afetivos e éticos do outro. Estes valores afetivos e éticos podem se tornar fundamentais na consolidação e manutenção dos dispositivos materiais de produção das estratégias instrumentais como, por exemplo, de comercialização.

Segundo Sabourin (2012a), baseando-se na teoria de Temple,

(...) existem várias estruturas elementares de reciprocidade nas quais as relações geram sentimentos diferentes e, portanto, valores diferentes. Existem, igualmente, várias formas de reciprocidade que lhes conferem imaginários diferentes. $O$ sentimento do ser originário pode ser capturado no imaginário do prestígio ou no da vingança, dando lugar a formas de reciprocidade positivas, negativas e simétricas. Estruturas ${ }^{10}$, níveis e formas se articulam para configurar sistemas de reciprocidade (SABOURIN, 2012a: $58)$.

A contribuição da teoria da reciprocidade de Dominique Temple é ter mostrado que os valores sociais, afetivos ou éticos, como identificados por Polanyi, por envolver as relações econômicas, não são dados, mas são precisamente produzidos e reproduzidos pelas relações de reciprocidade.

Sabourin (2009) analisou dois exemplos de relações estruturadas de reciprocidade ligadas à produção agropecuária no nordeste do Brasil: a ajuda

\footnotetext{
${ }^{10}$ Segundo Lévi-Strauss (1947), a noção de estrutura designa as diversas maneiras por meio das quais o espírito humano constrói seus valores e sistemas de valores.
} 
mútua (entre outras formas por meio de mutirões) e o compartilhamento de recursos comuns, como águas, sementes, trabalho e pastos. As prestações de ajuda mútua, a partilha de bens e o manejo coletivo de recursos comuns são exemplos de práticas econômicas baseadas na reciprocidade que são essenciais ao desenvolvimento da produção agrícola de agricultores familiares e à manutenção da coesão organizacional em torno de valores éticos e afetivos comuns (SABOURIN, 2009).

No caso de Mambaí, observamos as seguintes práticas de reciprocidade entre os agricultores dos assentamentos: a carona solidária, a comercialização cooperada, o compartilhamento de recursos (informações, saberes, técnicas), a "troca" ou repartição de produtos e pontos de venda, a troca de serviços sem câmbio monetário, a doação de excedentes, a venda na meia e a venda fiado.

As relações de reciprocidade extrapolam o âmbito da produção e permeiam as estratégias comerciais dos atores locais. Sabe-se que mercados não são constituídos unicamente pela lógica univalente das trocas capitalistas orquestradas pelo interesse individual de maximização do lucro, mesmo em mercados de grandes commodities. Pode-se observar nas estratégias comerciais mobilizados pela agricultura familiar a coexistência dialética entre 0 princípio da troca e o princípio da reciprocidade, constituindo formas de transação econômica híbridas onde pode haver a associação complementar entre os dois princípios (SABOURIN, 2009).

A teoria da reciprocidade considera a justiça, a responsabilidade e a confiança como valores éticos resultantes das relações sociais, importantes na reprodução dos ciclos de reciprocidade (SABOURIN, 2014). Em relação à confiança existe grande número de trabalhos com diferentes abordagens, predominando entre eles a concordância sobre o papel deste valor em melhorar coordenação de atividades econômicas de forma geral.

“(...) definimos a confiança como um determinado nível de probabilidade subjetiva com que um agente avalia que outro agente ou grupo de agentes irão realizar uma determinada ação. Assim, a confiança permite a quem confia empreender uma ação que envolva risco de prejuízo se o parceiro não executar a ação recíproca (...) (OSTROM e WALKER apud SABOURIN; 2014:129). 
Temple (1998) distinguiu que nas sociedades de reciprocidade a confiança é espontânea e flexível e que na sociedade dita moderna se torna cada vez mais uma obediência às obrigações pré-determinadas. No entanto, segundo Ostrom (1998), a confiança supõem obrigações, correspondendo a relações sancionadas: se ela não for respeitada pode resultar em punições, atuando como uma norma social das relações de reciprocidade.

Uma das abordagens que dissertam sobre o tema da confiança é a teoria da escolha racional. Essa teoria parte do pressuposto de que os atores sociais tomam suas decisões segundo um cálculo racional sobre o potencial de ganhos e perdas no ato de confiar segundo uma análise funcionalista onde a confiança é entendida como um instrumento para fortalecer as relações de troca mercantis. Buscamos, no sentido contrário, verificar as relações de confiança como resultado das relações econômicas e esclarecer o papel deste e de outros valores na sustentação das estratégias comerciais próprias de agricultores familiares, garantindo a visibilidade de distintas lógicas no processo de construção social de mercados.

"No Brasil, as feiras e outros mercados locais de proximidade proporcionam exemplos de formas comerciais que produzem vínculos sociais e mobilizam a sociabilidade por meio de relações diretas entre produtores e consumidores" (SABOURIN, 2009: 268). Essas estratégias de mercado, articulações intencionais de formas comerciais, são produzidas e reproduzidas por relações constituídas por valores e práticas regulados tanto pela lógica de troca como pela lógica de reciprocidade.

\subsection{Metodologia}

A metodologia se fundamentou, na primeira etapa da pesquisa, em análises bibliográficas e documentais. Os principais documentos foram 0 Diagnóstico Rural Participativo (DRP) desenvolvido pelo Projeto de Extensão (PROEXT) Promovendo o Uso do Cerrado em Pé e o relatório de campo desenvolvido pela disciplina Agricultura, Conservação e Desenvolvimento Rural Sustentável na Amazônia e no Cerrado, ambos do Programa de Pós- 
graduação em Desenvolvimento Sustentável da UnB. O DRP tratou dos assentamentos Capim de Cheiro, Mambaí e Paraná e o relatório sobre os assentamentos Cynthia Peter e Agrovila do Funil. Participei das pesquisas e elaboração dos dois referidos trabalhos e seus relatórios finais de forma voluntária, antes do início da presente pesquisa.

Análises bibliográficas e documentais serviram para compor uma primeira descrição do histórico da região, entendendo o contexto político e econômico de cada assentamento e esclarecendo a atuação de políticas públicas e ONGs nos assentamentos, o acesso à assistência técnica etc. Buscou-se considerar nas análises documentais os diversos âmbitos (sociais, econômicos, ambientais, etc.) e aspectos que poderiam estar relacionados direta ou indiretamente com a constituição das formas de comercialização. Esta estratégia permitiu a melhor elaboração dos questionários e a orientação eficiente das pesquisas em campo, segundo a realidade de cada assentamento.

Em seguida, realizou-se a identificação das formas de comercialização por meio de uma primeira pesquisa de campo exploratória voltada ao entendimento geral das estratégias comerciais desenvolvidas nos assentamentos de Mambaí. Para tanto, foi aplicado um questionário (ver anexo 1) cujas perguntas buscaram categorizar essas formas comerciais e quantificar quantos produtores praticam cada uma delas. $\mathrm{A}$ análise dos questionários deu lugar a uma tipologia das formas de comercialização com a identificação dos agricultores participando de cada uma delas ou de varias. A partir dessa tipologia, construiu-se uma amostragem dos agricultores a entrevistar de maneira aprofundada na segunda etapa da pesquisa. Esta primeira etapa não introduziu perguntas sobre as relações de reciprocidade presentes nos processos de comercialização, mas permitiu identificar diversas práticas de solidariedade e ajuda mútua entre os agricultores. 
Segue a grade de análise que orientou o referido questionário:

\section{Identificação das formas comerciais - entrevista semi-estruturada}

1. Formas comerciais

1.1 Venda direta ao consumidor

a) a) Venda direta porta-em-porta; b) Venda direta do lote; c) Venda direta na rua; d) Venda direta em feiras; e) Venda por encomenda.

\subsection{Venda indireta ao consumidor}

a) Venda para supermercados ou pequenos mercados;

b) Venda para atravessadores ou intermediários.

2. Estratégias de comercialização

a) Individual; b) Em grupo; c) Via organização.

I- Formal; II- Informal.

\section{Tipos de produtos}

a. Frescos; b) Pré-processados; c) Beneficiados.

Grade de Análise 1 - Identificação das formas comerciais

Essa pesquisa exploratória permitiu ainda visualizar a abrangência das formas de comercialização, muito além do que se imaginou, os tipos e quantidades de produtos comercializados pelos agricultores, a importância de cada forma de comercialização na composição da renda familiar e os custosbenefícios de cada uma delas.

Para a segunda etapa, na amostragem fez-se uma seleção das famílias representantes de cada forma comercial e que fossem testemunhos dos processos de construção social de mercados mais relevantes à pesquisa. Escolheu-se 12 famílias buscando ao menos 3 representantes de cada forma comercial identificada, priorizando aquelas famílias que (1) desenvolvem mais de uma forma comercial e que (2) possuem participação mais estável nos diferentes mercados locais e regionais.

As entrevistas abertas (ver anexo 2) tiveram como foco a origem e a trajetória das formas comerciais, a descrição das relações de reciprocidade e a caracterização dos problemas, tensões, alianças e cooperações relevantes à cada estratégia. Ainda, buscamos identificar o tipo de contrato usado, caracterizar as relações de troca, identificar os valores sociais gerados pelas relações simétricas ou assimétricas de mercado e verificar o papel das 
relações de reciprocidade na sustentação dos mercados promovidos pelos agricultores.

Veja grade de análise que orientou a segunda etapa da pesquisa:

\section{Caracterização das relações de reciprocidade e troca - entrevista aberta}

\section{Tipo de contrato}

a) Mercado spot $^{11} /$ sem contrato:

I - Venda esporádica; II - Venda regular

b) Contrato informal, baseado na confiança:

I - Preço fixo, definido unilateralmente II - Preço fixo negociado

c) Contrato formal III - Preço flexível negociado

2. Relações de troca:

a) Relações de troca e concorrência/competitividade;

b) Relações de reciprocidade dominadas pela lógica da troca material ou monetária. (Ex. na venda para supermercados, onde não há o diálogo e negociação de preços);

c) Relações híbridas: interação entre relações de troca e reciprocidade.

\section{Estruturas de relações de reciprocidade e de troca} Relação binária:

a) "cara a cara":

- Simétrica / ajuda mútua entre dois atores. (Ex. carona solidária, comercialização cooperada, contratos informais, mutirão para venda); Valores gerados: amizade, respeito, paridade.

- Assimétrica: (Ex. que causam dependência, sem negociação de preço etc.); Valores gerados: prestígio do doador, obrigação ou submissão do donatário.

b) Compartilhamento de recurso: (Ex. equipamentos, ferramentas e informações). Valores gerados: confiança ou/e equidade.

Grade de Análise 2 - Caracterização das relações de reciprocidade e troca

A nova feira de Mambaí começou a ser idealizada e promovida institucionalmente no segundo semestre de 2015, havendo reuniões de agricultores, encontro experimental da feira, mobilização nos assentamentos e articulação de apoios institucionais e privados. Estes foram acompanhados de

\footnotetext{
${ }^{11}$ Segundo Azevedo e Faulin (2005), o mercado spot representa aqueles mercados onde a negociação, o pagamento e a entrega dos produtos são efetivados em um mesmo instante. Este tipo de mercado é, segundo os autores, também denominado "mercado físico".
} 
perto, participando de reuniões formais e conversas informais e tratando especificamente do processo de construção social da feira nas entrevistas abertas.

A formação da nova feira não foi prevista e por isso não foi tratada neste trabalho de forma mais direta e pontual. Contudo, descreve-se todo o processo de ação coletiva e construção social desta forma comercial. Esta experiência se tornou um dos pontos principais de discussão e análise das relações de reciprocidade e ação coletiva nos processos de construção social de mercados e na formação das estratégias comerciais dos agricultores familiares em Mambaí.

A última etapa da presente pesquisa se dividiu em duas fases. Inicialmente, no intuito de entender de forma mais integral quais as principais práticas e relações de reciprocidade que contribuem à consolidação e manutenção das formas comerciais encontradas, aplicaram-se entrevistas abertas aos clientes (consumidores diretos) que faziam contato direto com os agricultores no ato da compra de seus produtos (Ver anexo 3). Como se identificou que na nova feira de Mambaí estavam se reunindo antigos e atuais consumidores das outras formas de vendas, como por encomenda, na rua e de porta em porta, aplicou-se estas entrevistas de forma geral nos frequentadores da feira.

A percepção dos agricultores e consumidores sobre o que é um "preço justo" foi objeto das entrevistas abertas. Buscou-se entender diferentes visões sobre o processo de construção social do preço e das relações de trocas mercantis, assim como elucidar os entendimentos sobre a importância do valor de troca em relação ao valor social das relações de reciprocidade. 
Segue grade de análise que orientou as entrevistas abertas junto aos consumidores, referente a $3^{\text {a }}$ etapa da pesquisa:

\section{Relações entre consumidores e produtores - entrevista aberta}

1. Práticas que contribuem à consolidação e manutenção dessa forma comercial:

a) Qualidade ou quantidade de produtos;

b) Regularidade da oferta;

c) Diversificação dos produtos;

d) Custo/benefício;

e) Acessibilidade, praticidade;

f) Fidelidade, relações afetivas

2. Relações que contribuem à consolidação e manutenção dessa forma comercial:

a) Proximidade;

b) Relação "cara a cara" na venda direta

c) Compartilhamento de recursos:

3. Valores produzidos por essas relações:
a) Confiança;
b) Credibilidade;
c) Amizade; Respeito;
d) Outros.

Grade de Análise 3 - Relações entre consumidores e produtores

Posteriormente, foram selecionadas duas famílias agricultoras diferentes que demonstraram ser de extrema relevância à descrição das formas comerciais e práticas cotidianas de reciprocidade a elas envolvidas. As duas famílias articulavam mais de 3 formas comerciais nas quais as relações de reciprocidade se mostraram fundamentais na reprodução de cada uma delas. Assim, acompanhamos estes dois agricultores em suas jornadas diárias de produção, beneficiamento e comercialização, observando de forma participante suas experiências e práticas cotidianas.

Observou-se cada caso durante alguns dias de forma presente e participativa. Ou seja, ajudei os agricultores carregando os produtos, transportando, entregando, negociando preços, vendendo, dialogando e trocando informações, atento às trocas de bens materiais e imateriais dentro e fora dos momentos de venda de seus produtos. Foram desenvolvidas conversas informais sobre o objeto da presente pesquisa de forma atenta às relações de reciprocidade e troca que muitas vezes não são consideradas 
pelos próprios indivíduos ou grupos na descrição dos seus processos cotidianos de comercialização. Ao final, as estratégias foram descritas minuciosamente, destacando os principais aspectos que contribuem à manutenção das respectivas formas comerciais, segundo as relações de reciprocidade identificadas.

O método da observação participante se justifica no presente projeto pelos limites que as entrevistas, de forma geral, têm em obter determinadas informações e entender práticas que são constituídas na intersubjetividade humana e cuja expressão prática permeia normas sociais estruturadas sobre valores por vezes contraditórios e opostos à determinados costumes, práticas e relações. A observação participante se insere de forma prática no cotidiano dos atores locais, permitindo verificar empiricamente e por meio de conversas informais as relações de troca e reciprocidade constituintes de suas estratégias comerciais, além de observar as capacidades individuais e coletivas de ação e suas dificuldades no processo cotidiano de construção social de mercados.

Sendo assim, a coleta dos dados se deu pela consulta de arquivos e documentos, pela aplicação de entrevistas e pela observação participante junto aos agricultores. A análise dos dados coletados durante as entrevistas (semiestruturada e abertas com produtores e com consumidores) se deu inicialmente pela sua leitura, codificação e organização por meio da segmentação em temas correlatos. Logo, sistematizou-se as informações obtidas durante as entrevistas e descreveu-se as formas comerciais e suas respectivas práticas de reciprocidade e troca. Analisou-se de forma preliminar os dados no intuído de obter uma percepção geral das informações. Essa percepção permitiu fazer a seleção dos casos que fizeram parte da metodologia observação participante, última etapa de campo da pesquisa. Na mesma, descreveu-se mais detalhadamente a articulação entre as estratégias comerciais e suas relações de troca e reciprocidade, aprimorando as informações e levantando observações complementares.

Por fim, verificou-se o papel das relações de reciprocidade na construção e sustentabilidade das referidas formas comerciais, buscando responder as hipóteses que inspiraram esta pesquisa. 


\section{ESTRATÉGIAS COMERCIAIS E RELAÇÕES DE RECIPROCIDADE EM ASSENTAMENTOS RURAIS NO MUNICÍPIO DE MAMBAÍ}

A região nordeste de Goiás foi consagrada com o título de Reserva da Biosfera de Goyas, pela UNESCO (Organização das Nações Unidas para a Educação, Ciência e Cultura), inserindo a mesma nas ações prioritárias de conservação da biodiversidade do Cerrado. Assim, segundo Carvalho (2003), se dá uma grande contradição: apesar da grande riqueza ambiental e cultural, a região apresenta os maiores problemas sociais e econômicos do estado. $O$ contexto territorial (solos pobres e arenosos) e climático (estação seca rigorosa e muito prolongada) favorece essa condição, além de um contexto econômico propício à intensificação das desigualdades sociais e perda das riquezas ambientais locais.

O nordeste do Goiás está inserido em um contexto de rápido avanço de uma nova fronteira agrícola (soja e algodão) e esteve historicamente associada à pecuária de larga escala e extração de madeira para produção de carvão, práticas não compatíveis com a conservação ambiental. Esta produção de carvão foi por muito tempo a única alternativa econômica de famílias assentadas no município. Hoje, esta atividade está em declínio por existir mais alternativas econômicas e pela crescente fiscalização do ICMBio.

Entre as famílias assentadas, existe alta dependência de donativos e auxílios do governo, especialmente programas de transferência de renda como a Bolsa Família e a Aposentadoria Rural. Os agricultores não possuem a Declaração de Aptidão ao Programa Nacional de Fortalecimento da Agricultura Familiar (PRONAF), ou seja, não cumprem as exigências para participar do Programa de Aquisição de Alimentos (PAA) e do Programa Nacional de Alimentação Escolar (PNAE). Sendo assim, nenhum assentado em Mambaí pode acessar compras públicas. Pelo mesmo motivo, não foram identificados agricultores assentados comercializando por meio de vendas formais, segundo contratos de compra e venda. 
Toda a produção agrícola do município é oriunda da agricultura familiar local. As poucas propriedades com mais de 4 módulos fiscais (máximo permitido à categoria da agricultura familiar) ocupam expressivas áreas e estão dedicadas unicamente à pecuária comercial. Contudo, praticamente todos os produtos comercializados pelos supermercados e outros mercados locais de Mambaí são oriundos da CEASA de Brasília. Nestes estabelecimentos, somente alimentos mais perecíveis, como a alface, o cheiro verde e a couve, são oriundos da agricultura familiar. Os donos dos mercados justificam sua preferência em comprar seus produtos da CEASA: os agricultores de Mambaí não produzem com regularidade e volumes satisfatórios, além de não emitirem nota fiscal, pois não possuem DAP (Declaração de Aptidão ao PRONAF ${ }^{12}$ ).

Existem projetos de apoio ao desenvolvimento local iniciados em cinco dos seis assentamentos rurais do município. Os projetos ECOFORTE e Assistência Técnica em Frutos do Cerrado, coordenados pela Fundação PróNatureza, visam fortalecer a cadeia produtiva de frutos do Cerrado. O Projeto Realidade, atuante nos PAs Capim de Cheiro, Paraná e Mambaí é voltado à superação da pobreza com a implementação de sistemas agroflorestais e fortalecimento do extrativismo. Estes projetos estão sendo executados de forma integrada à gestão da APANRV, pelo ICMBio. Todas estas iniciativas buscam favorecer o desenvolvimento dos assentamentos rurais, valorizando a agricultura familiar, por meio do incentivo à produção. Contudo, a comercialização continua sendo um desafio, pois esses projetos não contemplam o desenvolvimento de estratégias comerciais, apesar de admitirem sua fundamental importância.

As formas de comercialização promovidas pelos agricultores entrevistados pela pesquisa podem parecer, segundo um olhar produtivista industrial, irrelevantes tanto para o agricultor como para a economia regional pela sua escala reduzida. Contudo, como detalhamos mais adiante, essas estratégias comerciais contribuem de forma expressiva na composição da renda familiar da maioria dos agricultores locais e são articuladas com grande

\footnotetext{
${ }^{12}$ A DAP é utilizada como instrumento de identificação do(a) agricultor(a) familiar para acessar políticas públicas e emitir nota fiscal como produtor rural. Para obtê-la, o(a) agricultor(a) familiar precisa cumprir as exigências descritas na Lei 11.326, 24 de julho de 2006 (Lei da Agricultura Familiar).
} 
número de consumidores, motivados por produtos frescos e diferenciados, como, por exemplo, com distinção de origem.

Uma importante prática na região é o extrativismo, desenvolvido de forma comercial pelos agricultores assentados há pelo menos 10 anos. Constatamos em campo que estão crescendo as oportunidades dos agricultores em vender esse tipo de produto, principalmente o pequi (Caryocar brasiliense), por meio de vendas diretas e para cooperativas via atravessadores. Os frutos do Cerrado mais consumidos e comercializados são pequi, buriti, araticum e cajuzinho do cerrado. Outros frutos como o puçá (Mouriri pusa), o coco catolé (Syagrus oleracea), o baru (Dipteryx alata) e o jatobá (Hymenaea courbaril) são comercializados e consumidos em menor escala.

Atualmente, os produtos extrativistas comercializados recebem pouco beneficiamento e possuem pouco valor agregado. Quase todos os produtos extrativistas são vendidos hoje para atravessadores, que pagam um valor irrisório aos produtores. Esta prática é desenvolvida principalmente pelas mulheres e apresenta um grande potencial de incremento da renda nas épocas da frutificação. Além da polpa de pequi em conserva armazenada em garrafas pets, existe a produção de artesanatos com a palha de buriti, habitualmente vendido nas feiras e diretamente para conhecidos na cidade.

A pecuária nos assentamentos de Mambaí se caracteriza pela criação de animais de pequeno porte (como porcos, galinhas e cabras) e a pecuária extensiva de gado na solta. Os cultivos mais frequentes são o feijão catador, a mandioca, o milho, a abóbora, a batata doce e o arroz.

\subsection{Tipologia das formas de comercialização}

As famílias agricultoras assentadas em Mambaí possuem dificuldade em comercializar seus produtos por diversos fatores: a distância entre os assentamentos e seus consumidores, a falta de transporte público ou particular, o não cumprimento das exigências para obtenção da DAP (Declaração de Aptidão ao PRONAF) para emissão de nota fiscal, a falta de uma assistência técnica especializada que fundamente sua atuação a partir do 
interesse do agricultor e esteja preparada para promover formas de venda adequadas às suas respectivas formas de produção e interesses pessoais e 0 baixo valor agregado de seus produtos. O alto índice de analfabetismo (95,4\% dos agricultores adultos entrevistados não haviam terminado o ensino fundamental) é um fator que contribui na manutenção dessas populações em condições precárias de vida, dificultando qualquer iniciativa interna ou externa de promoção do desenvolvimento local. Contudo, esta situação não tem impedido que muitos agricultores e extrativistas realizem diversas formas de comercialização de seus produtos.

Durante o trabalho de campo, foram realizadas entrevistas semiestruturadas com 43 famílias, residentes nos seis assentamentos rurais de Mambaí. Andamos por todos os assentamentos, chamando os responsáveis por cada lote e entrevistando cada família. Buscamos, a partir de indicações dos entrevistados, encontrar outros residentes no assentamento. Nossa amostragem representou $13,7 \%$ de todas as 313 famílias registradas nos assentamentos. Apesar da opinião generalizada por parte de agentes públicos, assistentes técnicos e dos próprios assentados de que "praticamente ninguém" comercializava nos assentamentos em Mambaí, constatamos que, dos 43 entrevistados, 32 desenvolviam alguma forma de comercialização, de produtos agrícolas e/ou de produtos extrativistas.

A primeira distinção que precisamos fazer é entre as estratégias comerciais que o produtor vende diretamente ao consumidor final e as que 0 produtor vende para terceiros (estabelecimentos comerciais, agroindústrias, comerciantes, atravessadores ou intermediários), atores que cumprirão o ciclo fabril e/ou comercial dos produtos. Identificamos que $54 \%$ das estratégias comerciais desenvolvidas pelos agricultores que comercializam, na amostra descrita, são de venda direta ao consumidor final e 45,9\% de venda indireta. Porém, vale destacar que exatamente a metade das vendas indiretas identificadas corresponde a venda do pequi para atravessadores. 

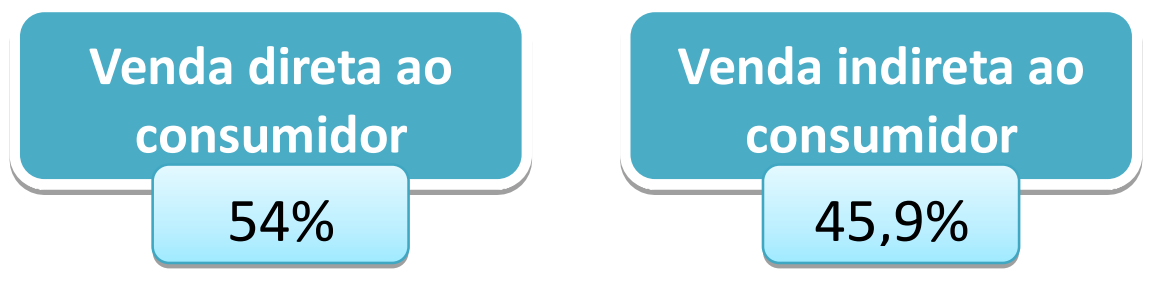

Identificamos as seguintes formas de comercialização:

a) venda direita aos consumidores: (1) na rua, (2) de porta em porta, (3) por encomenda, (4) em feiras e (5) as vendas efetuadas do próprio lote (para transeuntes ou conhecidos);

b) Venda indireta (6) para atravessadores, (7) para intermediários (8) para pequenos mercados locais (varejões, sacolões etc) e (9) para supermercados.

Chamamos de venda "no lote" a venda direta aos consumidores finais. As venda para atravessadores e intermediários, mesmo se efetuadas no próprio lote, são diferentes: o atravessador é historicamente caracterizado pelo distanciamento pessoal e pela imposição do preço. Constatamos que, quando existe uma aproximação pessoal entre produtor e este tipo de intermediário, a figura histórica do atravessador é descaracterizada. Sendo assim, diferenciamos nominalmente o atravessador de outros tipos de intermediários. Estes são caracterizados por uma relação de maior proximidade com 0 produtor, por estabelecer uma relação de mercado negociável e pelo conhecimento mútuo sobre a origem e o destino do produto. 
No gráfico $\mathrm{n}^{\circ} 1$ a seguir podemos verificar o número de agricultores que mobilizam cada uma das formas comerciais, segundo a origem dos produtos:

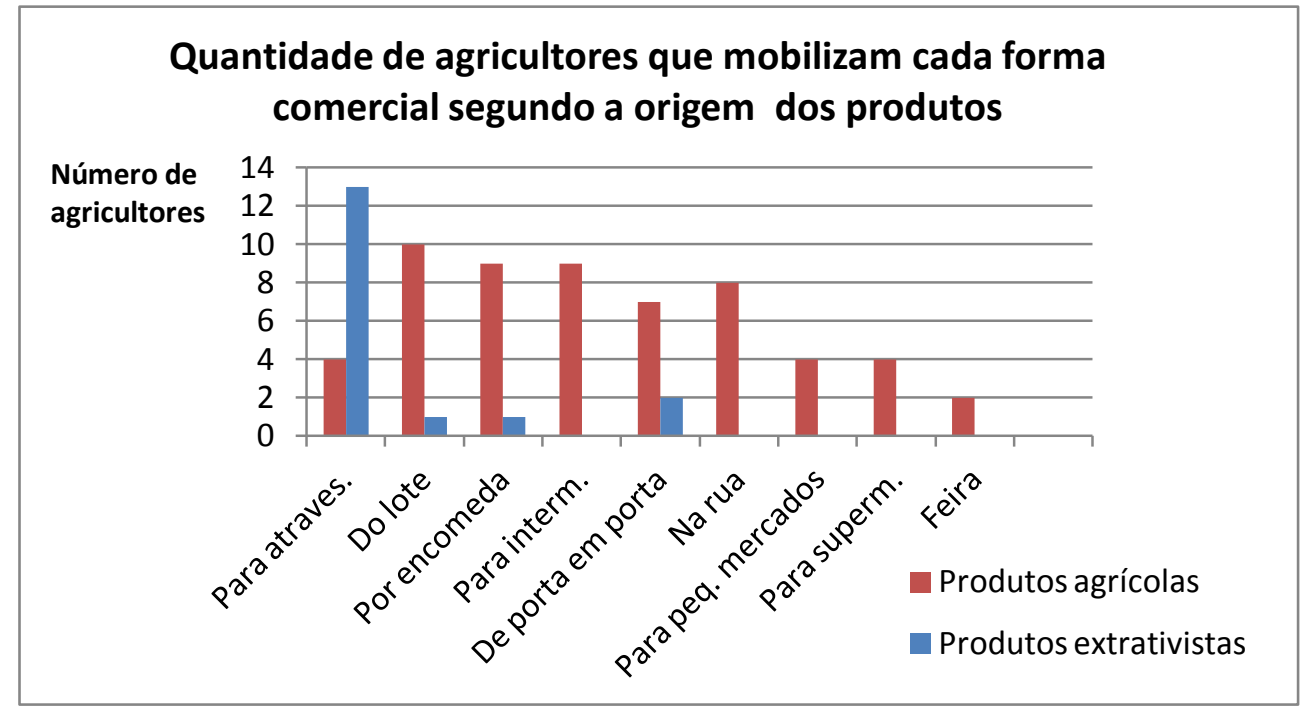

Gráfico 1 - Quantidade de agricultores entrevistados que mobilizam cada forma comercial Fonte: tratamento das entrevistas semi-estruturadas da pesquisa exploratória. Elaboração própria, 2016.

A grande maioria das formas comerciais de venda indireta de produtos agrícolas é mobilizada de forma irregular ou periódica ( $85,3 \%$ da amostra) e as vendas diretas são praticadas de forma mais regular (57\%) e com forte importância das relações de reciprocidade em sua constituição. Apesar de identificada intensa mobilização de relações de solidariedade entre agricultores e entre estes e seus consumidores, não existe nenhuma organização formal que coordene grupos, tanto na produção quanto na comercialização. As associações de produtores existentes nos assentamentos estão praticamente inativas e se relacionam apenas com pequenos grupos não representativos. Os moradores dos seis assentamentos declaram não acreditar em projetos coletivos e lembram vivamente das tentativas frustradas de organização comunitária, principalmente aquelas de projetos de financiamento via associação de agricultores dos assentamentos.

O pequi é o principal produto extrativista comercializado na região e, como podemos observar no gráfico $\mathrm{n}^{\circ} 1$, é praticamente todo vendido para atravessadores. Sua venda é feita de forma esporádica, na forma de conservas de polpa em garrafas pet. No tratamento dos dados a seguir, não 
consideramos a venda de pequi e outros produtos extrativistas, pois distorceria os resultados sobre a comercialização de produtos agrícolas. O pequi será tratado de forma específica na caracterização da venda para atravessadores.

A venda direta no lote é a estratégia comercial mais utilizada nos assentamentos em Mambaí, mas foi descrita como uma forma comercial pouco relevante. Esta venda é destinada a transeuntes e conhecidos visitantes e é desenvolvida de forma irregular, em pequenas quantidades. $\mathrm{Na}$ época da entrevista exploratória, a venda na feira era desenvolvida por apenas 2 agricultores que vendiam no município vizinho, Posse. Depois que surgiu a feira de Mambaí, identificamos mais de 5 agricultores re-orientando suas vendas para essa forma comercial. Os agricultores que já vendiam na feira descreveram esta forma comercial como muito relevante na composição de suas rendas. Os agricultores que estavam começando a vender na feira expressaram forte esperança em melhorar de vida com essa nova oportunidade de mercado.

As entrevistas mostraram que as formas de venda por encomenda, para supermercados e pequenos mercados locais são mobilizadas tanto como forma principal de venda como secundária e possuem importâncias variadas na composição da renda das famílias. Por outro lado, a venda para intermediários e atravessadores são majoritariamente estratégias secundárias que acompanham outras formas de venda, possuindo uma importância média na composição da renda das famílias.

Todas as formas comerciais identificadas se constituíram informalmente, se enquadrando como mercado "spot" (sem contrato ou qualquer tipo de acordo interpessoal) ou contratos informais (acordos informais ou "contrato sem papel", assim denominado pelos próprios agricultores da região). Não foram identificadas estratégias comerciais em Mambaí formalmente acordadas ou instituídas por contratos legais ou similares. Além disso, não foram identificados agricultores assentados em Mambaí com DAP ou que pudessem

\footnotetext{
${ }^{13}$ Segundo Azevedo e Faulin (2005), o mercado spot representa aqueles mercados onde a negociação, o pagamento e a entrega dos produtos são efetivados em um mesmo instante. Este tipo de mercado é, segundo os autores, também denominado "mercado físico".
} 
emitir notas fiscais ou recibos. Todos os agricultores familiares de Mambaí trabalham na informalidade.

O mercado spot é realizado geralmente em Mambaí na venda para atravessadores, na rua, de porta em porta e na feira, podendo ser de forma esporádica/irregular (por exemplo: quando houver excedente de produção), periódica (por exemplo: quando houver safra) e/ou frequente/regular (quando existe uma assiduidade na oferta de produtos). Identificamos que $68,9 \%$ dos agricultores pesquisados desenvolvem este tipo de venda.

O contrato ou acordo informal, quando se firma um compromisso mútuo sem a necessidade de sua formalização, é a preferência de muitos agricultores em Mambaí. Um exemplo é a venda direta ao consumidor por meio de encomendas regulares. Nesta forma existe um preço pré-estabelecido pelas repetidas experiências que confirmam reputações entre produtor e consumidor. Os agricultores costumam obter mais lucro por produto neste tipo de venda, pois existe uma valorização da origem diferenciada dos produtos. A venda para os pequenos mercados locais (sacolões, varejões e outros) e a venda para intermediários podem ser desenvolvidas nas duas formas apresentadas, tanto como mercado spot quanto por meio de acordos informais. Identificamos que $31 \%$ dos agricultores da amostra desenvolvem suas venda por meio de contratos/acordos informais
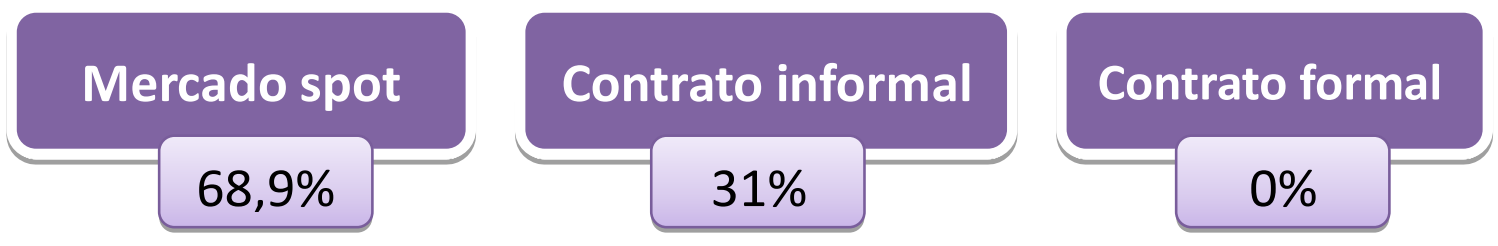

A tabela $n^{\circ} 1$, a seguir, apresenta de forma sistematizada os dados que levantamos durante a pesquisa exploratória, segundo a tipologia das formas comerciais: tipo de venda, forma comercial, tipo de contrato e suas respectivas características. Ou seja, a quantidade de famílias que mobilizam cada forma comercial, os principais produtos comercializados, a frequência (frequente 
regular, periodicamente ou irregular) e a importância descrita pelas famílias sobre a importância de cada forma comercial na composição de suas rendas totais (alta, média ou baixa).

Tabela 1 - Tipologia das formas comerciais e suas respectivas características dentro da amostra.

\begin{tabular}{|c|c|c|c|c|c|}
\hline $\begin{array}{l}\text { Tipo de } \\
\text { venda }\end{array}$ & $\begin{array}{l}\text { Forma comercial } \\
\text { e tipo de } \\
\text { contrato }\end{array}$ & $\begin{array}{l}\text { Quant. } \\
\text { de } \\
\text { Famílias }\end{array}$ & $\begin{array}{l}\text { Principais produtos } \\
\text { comercializados }\end{array}$ & Frequência & $\begin{array}{c}\text { Importância na } \\
\text { composição da } \\
\text { renda }\end{array}$ \\
\hline \multirow{15}{*}{$\begin{array}{l}\text { Venda } \\
\text { direta }\end{array}$} & \multirow{3}{*}{$\begin{array}{c}\text { Na rua } \\
\text { Merc. spot }\end{array}$} & \multirow{3}{*}{8} & \multirow{3}{*}{$\begin{array}{l}\text { Galinhas, ovos, } \\
\text { legumes e } \\
\text { tubérculos }\end{array}$} & Freq. regular: $62,5 \%$ & Alta: $0 \%$ \\
\hline & & & & Period.: 25\% & Média: $75 \%$ \\
\hline & & & & Irregular: $12,8 \%$ & Baixa: $25 \%$ \\
\hline & \multirow{3}{*}{$\begin{array}{l}\text { Porta em porta } \\
\text { Merc. spot }\end{array}$} & \multirow{3}{*}{7} & \multirow{3}{*}{$\begin{array}{l}\text { Hortaliças, } \\
\text { tubérculos e } \\
\text { legumes }\end{array}$} & Freq. regular: $71,5 \%$ & Alta: $0 \%$ \\
\hline & & & & Period.: 0\% & Média: $57 \%$ \\
\hline & & & & Irregular: $28,5 \%$ & Baixa: $43 \%$ \\
\hline & \multirow{3}{*}{$\begin{array}{l}\text { Por encomenda } \\
\text { Acordo informal }\end{array}$} & \multirow{3}{*}{9} & \multirow{3}{*}{$\begin{array}{l}\text { Galinhas, } \\
\text { hortaliças, } \\
\text { legumes e } \\
\text { tubérculos }\end{array}$} & Freq. regular: $44,5 \%$ & Alta: $11 \%$ \\
\hline & & & & Period.: $11 \%$ & Média: 55,5\% \\
\hline & & & & Irregular: $44,5 \%$ & Baixa: 33,5\% \\
\hline & \multirow{3}{*}{$\begin{array}{c}\text { Feira } \\
\text { Merc. spot }\end{array}$} & \multirow{3}{*}{2} & \multirow{3}{*}{$\begin{array}{c}\text { Frutas, hortaliças, } \\
\text { legumes e } \\
\text { tubérculos }\end{array}$} & Freq. regular: 50\% & Alta: $100 \%$ \\
\hline & & & & Period.: $50 \%$ & Média: 0\% \\
\hline & & & & Irregular: $0 \%$ & Baixa: 0\% \\
\hline & \multirow{3}{*}{$\begin{array}{l}\text { Do lote } \\
\text { Merc. spot }\end{array}$} & \multirow{3}{*}{10} & \multirow{3}{*}{$\begin{array}{c}\text { Galinhas, legumes } \\
\text { e tubérculos }\end{array}$} & Freq. regular: $0 \%$ & Alta: $0 \%$ \\
\hline & & & & Period.: 0\% & Média: $30 \%$ \\
\hline & & & & Irregular: $100 \%$ & Baixa: 70\% \\
\hline \multirow{12}{*}{$\begin{array}{l}\text { Venda } \\
\text { indireta }\end{array}$} & \multirow{3}{*}{$\begin{array}{l}\text { Para atravess. } \\
\text { Merc. spot }\end{array}$} & \multirow{3}{*}{4} & \multirow{3}{*}{$\begin{array}{l}\text { Frutas, legumes e } \\
\text { tubérculos }\end{array}$} & Freq. regular: $0 \%$ & Alta: $0 \%$ \\
\hline & & & & Period.: 50\% & Média: 75\% \\
\hline & & & & Irregular: $50 \%$ & Baixa: 25\% \\
\hline & \multirow{3}{*}{$\begin{array}{l}\text { Para intermed. } \\
\text { Acordo informal }\end{array}$} & \multirow{3}{*}{9} & \multirow{3}{*}{$\begin{array}{c}\text { Frutas, legumes, } \\
\text { hortaliças e } \\
\text { tubérculos }\end{array}$} & Freq. regular: $0 \%$ & Alta: $11 \%$ \\
\hline & & & & Period.: 45,5\% & Média: $66,5 \%$ \\
\hline & & & & Irregular: 55,5\% & Baixa: $22,5 \%$ \\
\hline & \multirow{3}{*}{$\begin{array}{l}\text { Para pequenos } \\
\text { comércios } \\
\text { Acordo informal }\end{array}$} & \multirow{3}{*}{4} & \multirow{3}{*}{$\begin{array}{l}\text { Hortaliças e } \\
\text { tubérculos } \\
\text { (mandioca) }\end{array}$} & Freq. regular: $50 \%$ & Alta: $25 \%$ \\
\hline & & & & Period.: $0 \%$ & Média: $50 \%$ \\
\hline & & & & Irregular: 50\% & Baixa: $25 \%$ \\
\hline & \multirow{3}{*}{$\begin{array}{c}\text { Para } \\
\text { supermercados } \\
\text { Acordo informal }\end{array}$} & \multirow{3}{*}{4} & \multirow{3}{*}{$\begin{array}{c}\text { Frutas, hortaliças } \\
\text { e tubérculos } \\
\text { (mandioca) }\end{array}$} & Freq. regular: $25 \%$ & Alta: $25 \%$ \\
\hline & & & & Period.: $0 \%$ & Média: $25 \%$ \\
\hline & & & & Irregular: $75 \%$ & Baixa: $50 \%$ \\
\hline
\end{tabular}

Fonte: tratamento das entrevistas semi-estruturadas da pesquisa exploratória. Elaboração própria, 2016. 
Nos assentamentos rurais de Mambaí existem agricultores que preferem atuar sozinho, outros em grupo; alguns preferem vender diretamente para 0 consumidor, outros vender para atravessadores; alguns preferem diversificar as formas comerciais, outros concentrar-se em uma só.

Existem formas que estão sustentadas basicamente por relações de troca, outras pela concomitância de relações de reciprocidade e de troca, com diferentes participações das relações de reciprocidade na manutenção de cada estratégia comercial.

Dentre as 32 famílias entrevistados que produzem e comercializam sua produção, $9(21 \%)$ deles praticam uma única forma de comercialização, 14 $(32,5 \%)$ mobilizam duas formas e $9(21 \%)$ mobilizam três ou mais formas de comercialização. Para cada uma dessas formas de comercialização existem diferentes maneiras de se organizar, estruturar as relações entre produtores e estabelecer relações com os consumidores finais, parceiros e intermediários.

As principais práticas de reciprocidade habitualmente desenvolvidas são: a carona solidária, a "troca" ou repartição de produtos, a divulgação cruzada, a "venda fiado" e a venda "em meeiro" ou "na meia"14.

\subsection{Caracterização das formas de comercialização}

O subcapítulo a seguir apresenta a caracterização das formas de comercialização desenvolvidas por agricultores familiares assentados rurais em Mambaí, a descrição das práticas e relações de reciprocidades relacionadas a elas e, por último, a descrição da articulação entre as diferentes formas comerciais identificadas.

\subsubsection{Venda na rua e de porta em porta}

Os projetos de assentamentos rurais em Mambaí possuem em média 15 anos de existência e muitos de seus assentados nunca haviam produzido ou

\footnotetext{
${ }^{14}$ Segundo um grupo de três agricultores que trabalham de forma cooperada na venda de produtos, a venda "em meeiro" é caracterizada quando um agricultor não pode ou não quer sair da propriedade para vender e deixa a mercadoria para outro vender em seu lugar, repartindo os ganhos pela metade entre quem produziu e quem vendeu a mercadoria.
} 
comercializado produtos agrícolas antes de ser assentado. A maioria destes novos agricultores iniciou suas tentativas de escoamento da produção indo para a rua, expondo seus produtos e conquistando sua clientela através do contato direto com o consumidor transeunte. Os agricultores que vendem na rua e de porta em porta não contam com um número fixo de consumidores regulares, procurando os mesmo quando possuem uma produção excedente. Dentre os entrevistados, $14 \%$ que comercializam produtos agrícolas vendiam na rua e $12,2 \%$ vendiam de porta em porta.

Analiso neste tópico as formas comerciais de venda na rua e de porta em porta por suas similaridades, contiguidades e complementaridades. Diferencio 3 sub formas características: (1) parado na rua, vendendo de forma aleatória para pedestres e motoristas transeuntes, (2) batendo de porta em porta, usando algum meio de transporte ou a pé e (3) mobilizando redes de conhecidos consumidores e amigos/familiares e indo diretamente ao encontro dos mesmos, seja na rua ou na casa dessas pessoas.

Segundo técnico da EMATER-GO, atuante no município há mais de trinta anos, a ocorrência dessas práticas foram influenciadas dez anos atrás por um programa do governo que incentivou os agricultores a produzirem e comercializarem leite ensacado, vendendo de porta em porta na cidade ${ }^{15}$. $\mathrm{O}$ programa durou pouco tempo, mas a prática de venda foi mantida por alguns.

A venda na rua e de porta em porta é usada principalmente pelos agricultores que produzem pouco e com baixa regularidade. São geralmente agricultores com poucas condições técnicas e financeiras e que entregam de forma periódica algum produto da estação. A venda na rua também é usada por quem está com algum excedente além do que consegue vender por meio de sua principal forma de comercialização. Este é o caso de Va. ${ }^{16}$ (PA São José) e de J. (PA Cynthia Peter): ambos procuram a venda na rua e de porta em porta como forma complementar de escoamento.

\footnotetext{
${ }^{15}$ Entrevista concedida em 07 de novembro de 2015.

${ }^{16}$ Serão utilizadas as iniciais dos nomes dos entrevistados de modo a manter seu anonimato.
} 


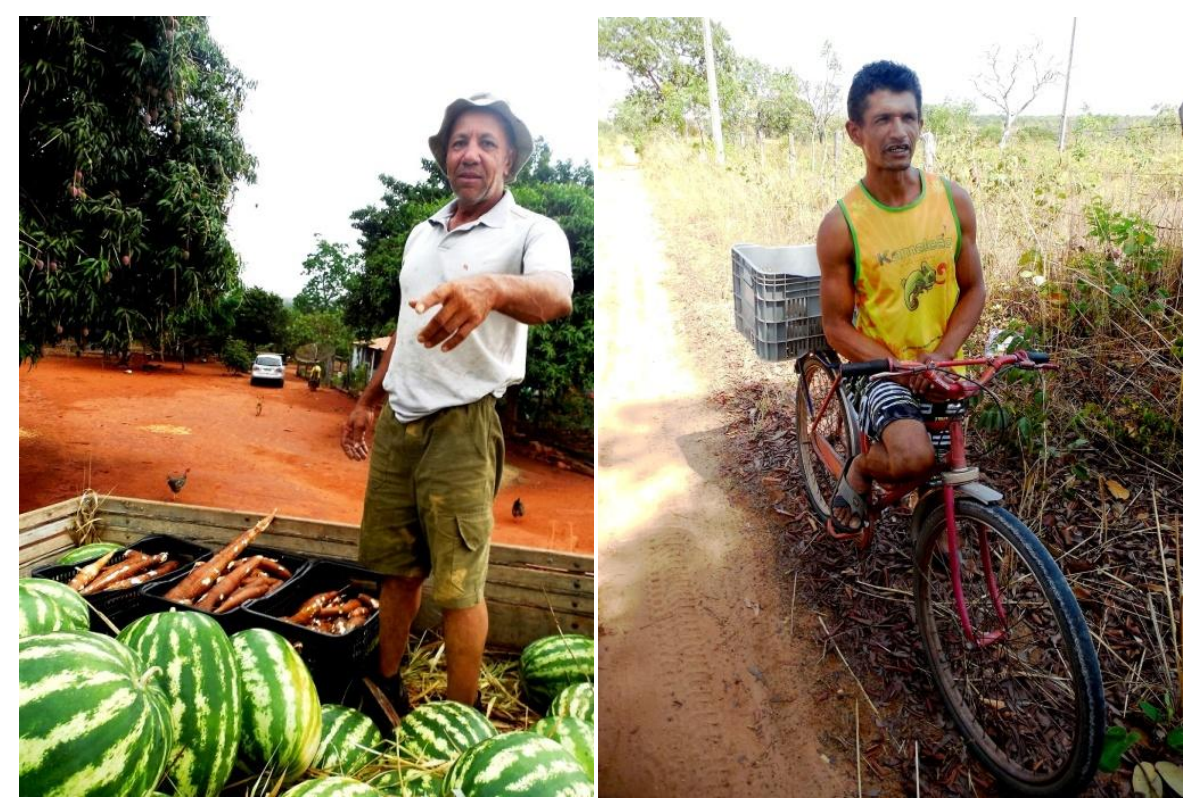

Figura 2: Va. (à esquerda) e J. (à direita). Trabalho de campo. Mambaí, 2016. Foto: Igor Aveline.

O agricultor vendedor, com o tempo, vai conhecendo melhor seus potenciais consumidores, seus hábitos e preferências de consumo. Vai também criando laços sociais de proximidade, de interconhecimento e de confiança gerados pelo contato direto que proporciona uma relação de reciprocidade repetida, recorrente e assim estruturada de tipo "cara a cara". A partir do momento que o vendedor passa a conhecer onde seu consumidor mora, a tendência é começar a ir diretamente até sua casa para oferecer os produtos, principalmente se possuir um carro, uma carroça, uma bicicleta ou outro meio de transporte. Muitos oferecem seus produtos na rua durante o translado entre a casa de cada consumidor de confiança, garantindo prioritariamente a satisfação deste último.

$\mathrm{Na}$ venda na rua observamos a importância da capacidade de criar relações sociais e tratamentos pessoalizados. Ap. (PA Paraná) relatou ter tentado vender na rua, mas "tem que saber falar e como falar para os clientes". Segundo ela "Uma vez fui pra rua tentar vender as coisas que tinha. Mas não deu certo, perdi a voz e não consegui vender". Segundo outra assentada, com o tempo as pessoas vão tomando afinidade e conhecendo melhor seus produtos. Segundo Jo. "Vendi mais de vinte anos na rua. O povo me conhece, sempre vendia tudo". Segundo Jo., o estreitamento dos laços e o 
interconhecimento pela progressiva aproximação entre consumidor e produtor gera mais simpatia e até confiança facilitando a venda.

$\mathrm{Na}$ rua, o agricultor costuma receber o dinheiro no ato da venda. $\mathrm{Na}$ venda de porta em porta, quando frequente e se existe uma relação de confiança consolidada, o hábito é de receber o pagamento dos produtos somente no final do mês. Esta prática também ocorre na venda por encomenda e é denominada pelos agricultores venda "fiado". Questionados sobre a origem desta prática, alguns não souberam responder e lamentaram esse hábito. Outros como Ap., Jo., e outros disseram que preferiam receber tudo junto no final do mês, porque conseguiam melhor administrar as economias de casa. A venda fiado foi naturalizada e não sofre grande resistência por parte dos agricultores.

A prática de vender fiado acontece, segundo Jo. (PA Agrovila do Funil), “(...) porque a gente conhece o povo há muito tempo. Eles (os clientes) preferem assim e a gente não quer ficar com tudo (com a produção) parado". Ou seja, o agricultor vende fiado quando possui uma confiança consolidada, buscando atender a preferência dos seus clientes. Jo. explicou: “(...) é bom pra gente também. Eles gostam e pegam (compram) na nossa mão sempre. A gente recebe no final do mês".

Assim, constatamos que existe uma fidelização do cliente quando se confirma o compromisso mútuo na venda fiado. O fortalecimento destes laços sociais permite consolidar relações de mercados mais regulares e perenes, conferindo um pouco mais de segurança e estabilidade econômica ao agricultor.

$\mathrm{Na}$ venda de porta em porta, os agricultores costumam priorizar um determinado cliente com quem existe um laço de confiança bem estruturado e assim, a segurança de vender seus produtos por um preço já acordado e receber de forma correta. Na venda de porta em porta, os clientes que não negociam preço e que são de confiança são prestigiados, podendo até receber pequenas doações. Segundo dona Jo., "procuro cultivar esses clientes de confiança. Não posso vender (fiado) para quem eu não confio". Outra prática é 
oferecer descontos para garantir a venda de determinado produto e/ou conquistar a fidelidade do cliente. Descontos e venda fiado se caracterizam como práticas de uma relação de reciprocidade binária "cara a cara" que tende a fortalecer a produção de valores afetivos de amizade e logo de fidelidade entre agricultor e consumidor.

Nestes casos, onde os laços de confiança se fortalecem e as relações de proximidade se estreitam, a transação costuma se transformar em venda por encomenda. Os clientes passam a pedir determinados produtos, expressar suas preferências e buscar garantir seu abastecimento. Na venda por encomenda existe um duplo contato direto entre agricultor e consumidor: no primeiro momento são estabelecidos o conteúdo, a forma, o preço e o momento da entrega, que corresponde ao segundo contato direto para a transação propriamente dita. Esta estratégia pressupõe a confirmação de compromissos mútuos (contrato informal) e o compartilhamento de valores éticos de respeito e de confiança que podem também evoluir para valores mais afetivos, gerando até amizade.

Foram identificados ainda casos em que são "trocados" produtos entre pares de agricultores para ambos garantirem o fornecimento dos produtos desejados por seus clientes, mantendo assim satisfação e fidelidade na venda de porta em porta. Essa forma de "troca" não monetária representa também uma prática de ajuda mútua habitualmente desenvolvida entre vizinhos de cada assentamento.

Duas das maiores dificuldades citadas pelos agricultores na venda na rua e de porta em porta são os gastos com combustível e com tempo na entrega dos produtos. Segundo eles, a excessiva procura por descontos nesse sistema de comercialização pode também implicar em prejuízos. 


\subsubsection{Venda por encomenda}

A venda por encomenda é praticada por $15,7 \%$ dos entrevistados e é por eles considerada a mais interessante forma de comercialização, referida como de alta importância na composição da renda familiar. Apesar de ser maior o número de agricultores $(17,5 \%)$ que vendem no próprio lote (para conhecidos, transeuntes e outros compradores individuais que buscam nos assentamentos produtos de qualidade diferenciada) a venda no lote foi considerada pelos agricultores como pouco relevante na composição das rendas familiares.

Existem agricultores que praticam a venda por encomenda ou de porta em porta por opção, por gostarem das relações sociais de proximidades inerentes as vendas diretas. Existem outros que continuam mobilizando estas formas de venda por conta de uma irregularidade na sua produção e por produzirem fora dos padrões de qualidade (estéticos, sanitários etc.) exigidos em outras formas comerciais formais como na venda para supermercados.

Como exposto anteriormente, a quase totalidade dos agricultores que vendem por encomenda recebe somente ao final do mês. Esta venda fiado se tornou tradição e exige a consolidação de laços fortes de confiança entre o agricultor e consumidor. Os agricultores descreveram seus clientes como amigos próximos e valorizaram o hábito de trocar informações sobre questões pessoais, técnicas de produção, receitas culinárias, dificuldades financeiras etc. Esta afirmação fica clara na fala de Vi. (PA São José): “(...) a gente conversa muito, é tudo amigo. Estamos sempre conversando, quando tenho um problema ou eles também. A gente sempre se ajuda na dificuldade"17.

Como podemos ver, estas trocas de informações e expectativas foram descritas pelos agricultores como mecanismo de aprendizagem mútua e de valorização do saber fazer do agricultor. Observamos ainda que estes laços de reciprocidade estruturam a relação de troca comercial na venda por encomenda, conferindo segurança e estabilidade às vendas. Estas relações se tornam ainda mais importantes se pensarmos que muitas destas famílias vivem em situação de risco social, pobreza e insegurança econômica.

\footnotetext{
${ }^{17}$ Entrevista concedida no dia 06 de novembro de 2016.
} 
Existem casos em que o próprio consumidor procura o agricultor para pedir os produtos desejados (por telefone, pessoalmente ou por um informante) e casos em que o agricultor procura o consumidor, divulgando seus produtos. Existem ainda os casos mais consolidados onde 0 agricultor leva semanalmente uma cesta de alimentos pré-estabelecida. Todos os agricultores entrevistados que desenvolvem esta forma de venda possuíam entre 05 a 15 consumidores regulares por encomenda. Geralmente os produtos vendidos por essa forma de comercialização em Mambaí são: mandioca, batata doce, abóbora, jiló, maxixe, feijão, milho verde, quiabo, alface, couve, cheiro verde e galinha caipira. A regularidade de entrega varia, podendo ser semanalmente, quinzenalmente ou esporádica.

Ap. ${ }^{18}$ (PA Paraná) produzia galinha caipira e vendia de porta em porta. Rapidamente esta agricultora passou a ser procurada por conhecidos para vender por encomenda e um grande restaurante de Mambaí começou a pedir semanalmente uma quantidade pré-estabelecida de galinhas. Ap. nunca fez um contrato, mas descreve os laços de confiança e compromissos recíprocos como um contrato: "(...) era assim tipo um contrato, eu sempre entregava. Eles eram de confiança, mesmo".

Ad. ${ }^{19}$ (PA São José) costuma vender galinha caipira, feijão e rapadura para intermediários. Contudo, sua rapadura é apreciada pelos seus vizinhos que the fazem encomendas. Ad. nunca vende toda a rapadura de forma indireta, pois the agrada vender também para seus conhecidos.

\footnotetext{
${ }^{18}$ Entrevista concedida no dia 06 de novembro de 2015.

${ }^{19}$ Entrevista concedida no dia 05 de novembro de 2015.
} 


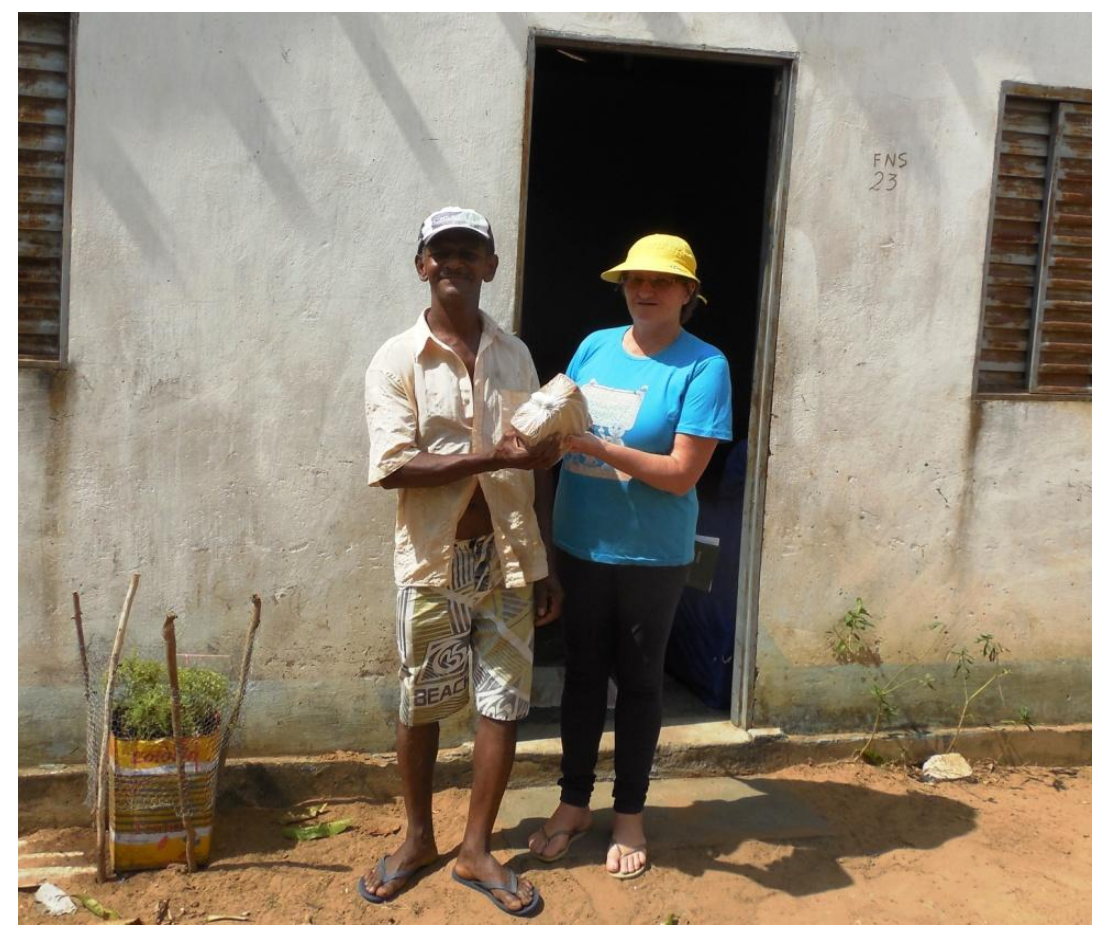

Figura 3: Ad. (à esquerda) vendendo por encomenda. Trabalho de campo. Mambaí, 2016. Foto: Igor Aveline.

Hoje, muitos dos agricultores que vendiam de porta em porta ou por encomenda estão passando a vender diretamente na feira do agricultor familiar, iniciada em novembro de 2015. A feira concentrou os espaços de venda direta ao consumidor, antes desenvolvidas de forma descentralizada pela cidade. A feira está sendo mais vantajosa para o agricultor, pois recebem o dinheiro no momento da venda (não vendem fiado), vendem parados em um mesmo local sem precisar gastar muito tempo e combustível em deslocamentos, administram mais facilmente as finanças familiares (pois recebem de todos os clientes em um mesmo dia), os clientes da feira negociam menos os preços dos produtos e encontram outros agricultores, amigos e consumidores. Segundo alguns entrevistados, o melhor da feira é "ver o movimento da cidade".

\subsubsection{Venda na feira do agricultor familiar de Mambaí}

A prefeitura em parceria com a EMATER-GO e a Secretaria de Turismo inaugurou a nova feira do agricultor familiar de Mambaí no final de 2015. 
Apesar do grande entusiasmo de todos e do alto impacto no cotidiano dos assentados, essa não foi a primeira vez que tentaram instituir uma feira da agricultura familiar no município.

Há 10 anos, a prefeitura por meio de um programa do governo (PRONAF Infraestrutura) construiu um grande balcão para abrigar uma feira do agricultor familiar. $\mathrm{Na}$ época, o apoio da prefeitura foi somente em relação à construção do espaço da feira. Por outra parte, a assistência técnica nos assentamentos era reduzida e os agricultores careciam de estruturas como sistema de distribuição de água, boas estradas, transporte público e, alguns, até de energia elétrica. Sendo assim, existiam poucos agricultores na região capazes de produzir com quantidade e regularidade para atender a demanda de uma feira. Cada agricultor ou associação de agricultores ficou responsável por resolver a forma como transportar seus produtos para a cidade.

Segundo técnico da EMATER responsável pela região, a feira começou muito bem, mas em menos de três meses não havia mais oferta de produtos e havia poucos agricultores participando. Em seis meses a feira parou de funcionar e a única venda que sobreviveu foi a do bar, vendendo bebidas alcoólicas nos finais de semana. O espaço da feira foi então alugado para virar um restaurante. O restaurante funciona até hoje e é o mais conhecido e frequentado da cidade. $\mathrm{O}$ acordo firmado com o Sindicato dos Agricultores Familiares de Mambaí foi que o aluguel do espaço iria para um fundo de apoio à agricultura familiar. Com esse dinheiro a prefeitura conseguiu comprar um caminhão, duas batedeiras de cereais, uma roçadeira e uma carreta, administrados pela Secretaria de Agricultura e usados coletivamente pelos agricultores.

A nova feira de Mambaí, inaugurada em novembro de 2015, foi resultado de uma ação coletiva com a participação de diversos atores sociais como agricultores, moradores da cidade, organizações da sociedade civil (ONG Mutirão Agroflorestal e Funatura), secretarias municipais, a prefeitura e gestores do ICMBio. Os principais atuantes a nível institucional são a EMATER-GO e a Secretaria de Turismo, possuidores de cadeiras no Colegiado de Desenvolvimento Territorial Rural (CODETER) do Território da Cidadania 
Vão do Paranã. A feira não conseguiu verbas, mas o colegiado está elaborando um projeto para ampliação do espaço da feira a ser encaminhado ao MDA.

Agricultores como Fe., Au., Jo., Va. e M., de diferentes assentamentos, declararam ter pressionado a prefeitura pela reabertura da feira de Mambaí e estimulado durante anos o debate sobre os benefícios de uma feira do agricultor familiar. Segundo Jo. e Au., elas já haviam conversado pessoalmente com o atual prefeito sobre a importância de uma feira. Desde que a feira começou, há menos de 2 meses, elas estão convidando outros agricultores a participar. Outros também atuaram incentivando agricultores vizinhos a participar, mobilizando pessoas da cidade para frequentarem a feira, promovendo e participando de reuniões, dialogando e ajudando na concepção da feira.

A ação de diversas instituições como o ICMBio, a ONG Mutirão Agroflorestal e a Fundação Pró-Natureza estimularam a organização e a divulgação da feira e contribuíram na mobilização dos agricultores. Em julho de 2015, representantes do ICMBio (gestores da APA Nascentes do Rio Vermelho) organizaram com algumas agricultoras do PA Agrovila do Funil um dia de feira experimental para observar 0 interesse dos agricultores e dos consumidores e a viabilidade geral da feira. Segundo as agricultoras Au. e $\mathrm{Fe}^{20}$, esse dia foi um sucesso. Elas convidaram os possíveis parceiros da feira para participar, ofereceram principalmente produtos processados (bolos, pães e salgados) e venderam tudo.

Antes de iniciar a feira houve uma reunião para organizar e pensar o formato da mesma. A reunião teve a presença de 27 agricultores, de um representante do ICMBio e outro da ONG Mutirão Agroflorestal, o prefeito de Mambaí e os responsáveis da Secretaria de Turismo e da EMATER-GO.

\footnotetext{
${ }^{20}$ Entrevistas concedidas entre os dias 26 e 27 de janeiro de 2016.
} 


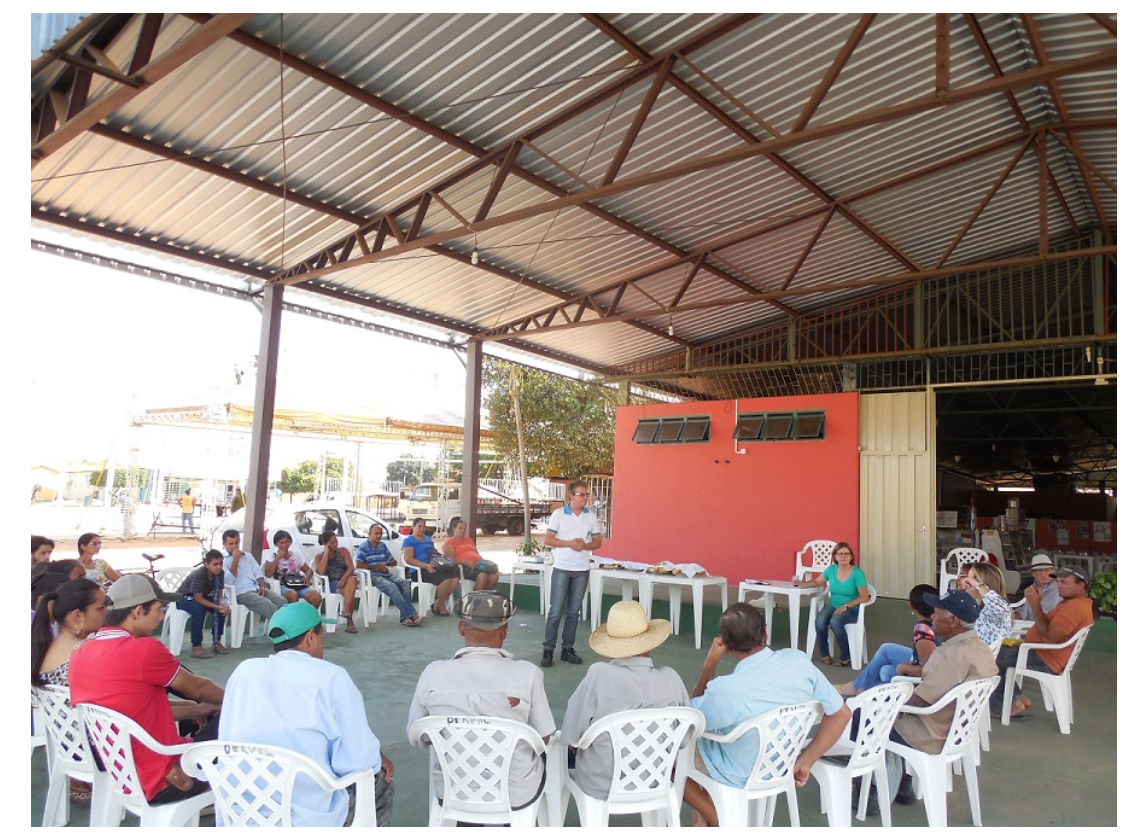

Figura 4: Reunião de organização da feira. Trabalho de campo. Mambaí, 2016. Foto: Igor Aveline.

Nesta reunião houve um debate sobre o formato da feira: periodicidade, dia da semana, horário de funcionamento, quem poderia participar e como seria a logística da feira. Também foram expostos compromissos por parte da prefeitura em ceder o espaço da feira e atribuir à Secretaria de Turismo o dever de atuar na promoção da mesma.

Durante a reunião, alguns agricultores mais experientes expressaram que a feira deveria ser semanal. M. (PA São José) exclamou: “(...) se a feira for quinzenal, ou mais (mensal), não vai pegar". A grande maioria concordou que para a feira funcionar e tornar parte do cotidiano da cidade deveria acontecer semanalmente. A questão mais polêmica foi em relação a permitir ou não que pessoas de fora do município participassem da feira, assim como permitir ou não a venda de produtos da grande produção latifundiária. Apesar do dissenso, a opinião mais aceita foi de que os agricultores familiares de Mambaí ainda não possuíam capacidade para compor uma feira com a diversidade de produtos necessária para torná-la atraente para o consumidor em geral. Sendo assim, decidiu-se por permitir que pessoas de fora e intermediários da produção monocultora participassem da feira até que os agricultores familiares de 
Mambaí alcançassem capacidade de fornecer uma quantidade significativa de produtos.

Outra questão polêmica foi a necessidade do compromisso da prefeitura na disponibilização de transporte aos agricultores nos assentamentos durante os dias da feira, sem a qual não seria viável segundo os próprios agricultores. Poucos agricultores possuem transporte próprio e não produzem pela incerteza de conseguir transportar e vender seus produtos. Foi exposto que se houvesse a certeza do transporte muitos agricultores começariam a produzir.

Os agricultores relataram experiências nos municípios vizinhos: Buritinópolis e Posse. Em Posse, a prefeitura disponibilizou transporte para os agricultores durante quase um ano e a feira conseguiu funcionar satisfatoriamente. Relataram também que com a participação dos agricultores e consequente interesse dos mesmos, quando terminou o acesso ao transporte público eles foram capazes de solucionar suas dificuldades e buscar formas alternativas de transporte. Na feira de Buritinópolis não houve esse apoio da prefeitura e, em um ano, faltavam produtos na feira dada a baixa participação dos agricultores. Logo, a mesma parou de funcionar. Desta forma, no final da reunião, a prefeitura se comprometeu em disponibilizar o transporte escolar nos assentamentos antes e depois da feira para que todos pudessem participar.

O espaço que os agricultores conseguiram para a feira é uma pequena área externa e coberta localizada na frente do restaurante locado no espaço da antiga feira. No momento a Secretaria de Turismo está alugando as mesas do próprio restaurante para os agricultores exporem seus produtos. Pretende-se ampliar e estruturar o novo espaço da feira por meio dos fundos do programa Territórios da Cidadania (PTC) do Ministério do Desenvolvimento Agrário mediante CMDRS de Mambaí. A contrapartida local seria financiada com o dinheiro arrecadado pelo aluguel do antigo espaço da feira. Hoje, praticamente nenhum agricultor participa deste conselho municipal e 0 interesse dos mesmos é pautado pelo representante da EMATER-GO no município.

A Secretaria de Turismo, a EMATER-GO e alguns poucos agricultores se apropriaram da organização e logística da feira. Destaca-se a atuação de 
liderança da agricultora Au. (PA Agrovila do Funil) que passou de lote em lote em todos os assentamentos chamando os agricultores a participarem da feira e vem atuando ativamente na sua organização.

Existem reclamações por parte dos responsáveis da Secretaria de Turismo e da EMATER-GO que a grande maioria dos agricultores não ajuda na organização da feira, não participa da logística e não limpa o espaço encerradas as atividades. Os agricultores comentam que querem contratar uma pessoa para limpar o espaço da feira, mas a secretária de turismo comentou em entrevista ${ }^{21}$ que, na sua opinião, isso devia ser feito por eles mesmos. Segundo a secretária, essas dificuldades não estão sendo resolvidas porque, desde que se iniciou a feira, não está havendo um momento de diálogo entre os envolvidos.

Existem produtos que são mais vantajosos ao agricultor se vendidos por encomenda, outros se vendidos na feira. Um exemplo é a galinha, pois o preço base da galinha na feira está sendo estipulado segundo o preço do frango vendido nos mercados locais. Segundo $\mathrm{Au}^{22}$, esse preço não compensa porque seus produtos são diferenciados e deveriam custar mais. Contudo, Au. admite que se o valor cobrado for maior que o preço dos mercados eles não conseguem vender. Segundo Ro. ${ }^{23}$ (PA São José) essa situação é temporária, “(...) até os consumidores entenderem o valor dos produtos artesanais, sem veneno". Segundo os agricultores, a galinha caipira é vendida com um preço justo na venda por encomenda, pois esses consumidores sabem a origem e a qualidade superior dos produtos. Outro caso é a farinha de mandioca. Esta não é vantajosa ao agricultor na venda por encomenda, pois o retorno econômico é pequeno vendendo de forma fracionada. Contudo, a farinha de mandioca é um produto muito procurado por todos na feira e os agricultores conseguem vender grandes quantidades. De forma geral, os feirantes combinaram em reunião de deixar o preço mais baixo que os mercados locais como estratégia para consolidar a freguesia.

\footnotetext{
${ }^{21}$ Entrevista concedida no dia 29 de janeiro de 2016.

${ }^{22}$ Entrevista concedida no dia 27 de janeiro de 2016.

${ }^{23}$ Entrevista concedida no dia 25 de janeiro de 2016.
} 


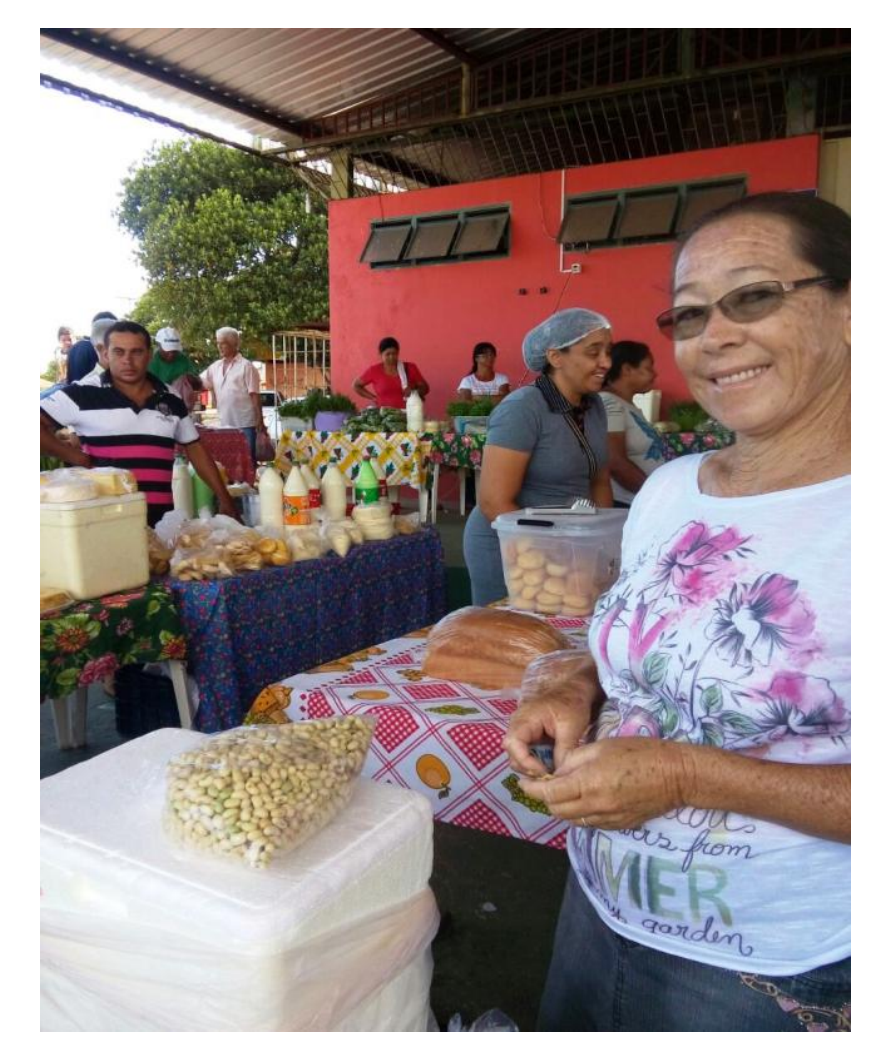

Figura 5: Nova feira do agricultor familiar de Mambaí. Trabalho de campo. Mambaí, 2016. Foto: Igor Aveline.

$\mathrm{Na}$ feira, como na venda por encomenda e de porta em porta, foi identifica a "troca" de produtos entre pares de agricultores como forma de reciprocidade binária de ajuda mútua voltada à diversificação de produtos entre produtores em busca da satisfação de seus clientes. Esta prática acontece quando um agricultor está produzindo pouco ou nada de um produto desejado pelos seus clientes e outro agricultor the oferece parte de sua produção para ajuda-lo. Esta ajuda pode ser feita pela troca ou pela venda de produtos pelo seu preço padrão, ou ainda por uma doação. Segundo dois agricultore ${ }^{24}$ do PA São José, esta prática acontece entre conhecidos feirantes e ocorre independentemente se o agricultor que está ajudando tiver capacidade ou não de vender seus produtos na feira. Logo, configura-se como uma forma de parceria entre agricultores e contribui, segundo os entrevistados, a manter a fidelidade e a credibilidade entre os produtores e seus clientes.

\footnotetext{
${ }^{24}$ Entrevistas concedidas nos dias 25 e 26 de 2016, respectivamente.
} 
Outra prática é a troca de serviços ou o pagamento de serviços por produtos ou outros favores, sem haver câmbio monetário. Na foto a seguir, Va. monta seu espaço na feira de Posse com a ajuda de dois amigos. Estes ajudam a descarregar a caminhonete, a ensacar e contar produtos. Ao final da feira, durante a observação participante, constatei que Va. oferecia frutas e verduras em troca desta ajuda.

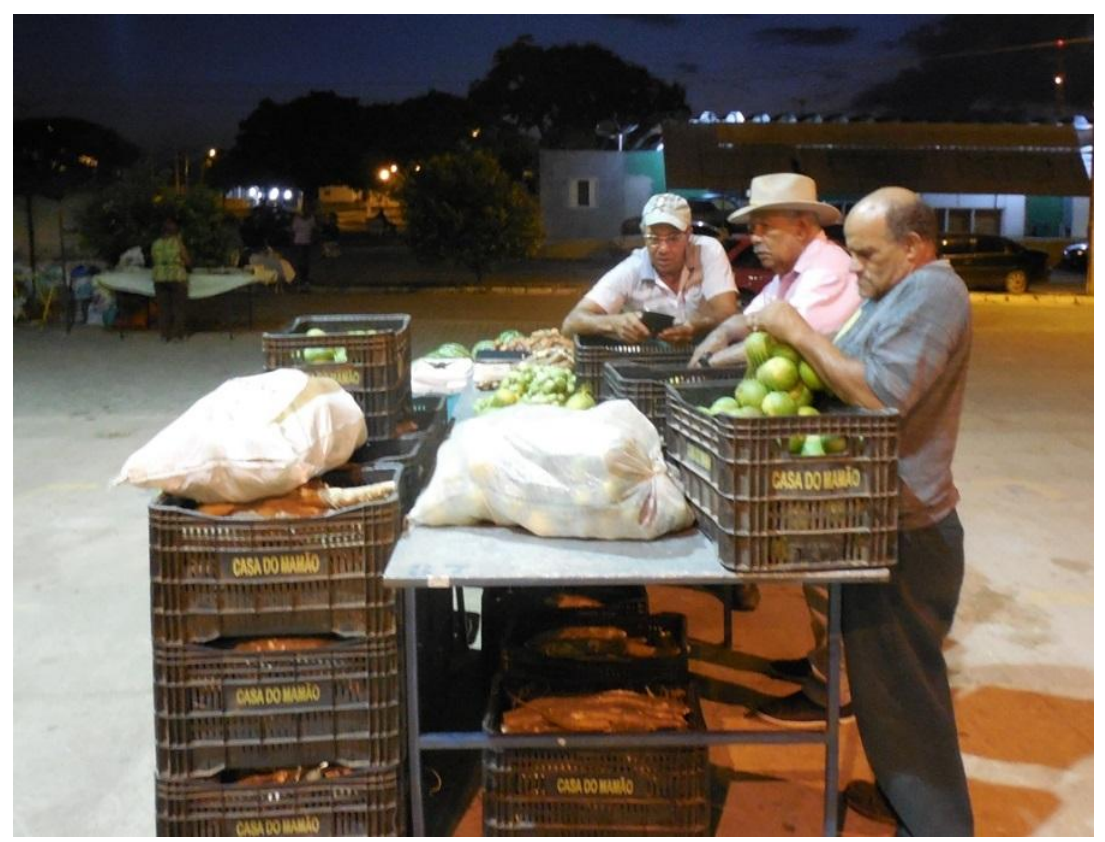

Figura 6: Va. e seus dois ajudantes na feira de Posse. Trabalho de campo. Mambaí, 2016. Foto: Igor Aveline.

Outra forma de reciprocidade observada no acompanhamento da feira foi a divulgação cruzada dos produtos oferecidos na feira. Esta prática se configura como uma relação de partilha de informação entre os participantes da feira. A carona solidária entre feirantes e a partilha de ponto de venda com outros produtores também se configuraram como relações de ajuda mútua que, ao mesmo tempo, resolvem aspectos materiais de interesse mercantil e intensificam laços sociais de parceria.

A feira de Mambaí oferece hoje uma diversidade de produtos e, assim, uma diversidade de possibilidades à produção familiar, tanto para agricultores como para pessoas da cidade. Muitas agricultoras feirantes disseram vender 
muito bem produtos como sucos, bolos, biscoitos, tapiocas e pães produzidos a partir de frutos do cerrado. Por isso, F. ${ }^{25}$ (PA Agrovila do Funil) comentou que, por conta da demanda, tem coletado fora do seu lote diversos frutos do cerrado e se preocupado mais com a conservação local. Produtos como mudas de plantas, caldo de cana, café, misto quente, doces e outros itens para o consumo imediato também são produtos vendidos na feira. A oferta de verduras e hortaliças ainda está reduzida, segundo a maioria dos frequentadores da feira ${ }^{26}$.

A feira ainda está em estágio de adequação e consolidação. Na visão dos organizadores, com a permanência do transporte para os agricultores, a tendência é aumentar a adesão dos mesmos e, em breve, será necessário o aumento do galpão da feira. Perguntados sobre o que seria mais importante para a mesma continuar funcionando, crescendo e beneficiando os agricultores, tivemos respostas convergentes e complementares: fortalecer a organização dos agricultores, aumentar a capacidade produtiva dos mesmos e conseguir um espaço melhor e mais adequado para a feira. Segundo técnico da EMATER-GO, os maiores desafios à consolidação da feira é "(...) superar a desunião entre os agricultores e aumentar a produção de alimentos nos assentamentos rurais da região"27.

\subsubsection{Venda no lote diretamente para o consumidor final}

A venda direta feita no lote foi a forma comercial mais identificada em campo, praticada por $17,5 \%$ das famílias entrevistadas. Contudo, é a forma menos representativa na composição da renda familiar por ser muito irregular. Muitos agricultores assentados em Mambaí recebem visitas esporádicas de pessoas conhecidas e desconhecidas que estão à procura de produtos "direto da roça" ou "sem veneno", como alguns explicaram.

Os assentamentos mais próximos da cidade recebem mais consumidores deste tipo e conseguem estabelecer melhor essa forma de

\footnotetext{
${ }^{25}$ Entrevista concedida no dia 26 de janeiro de 2016.

${ }^{26}$ Entrevistas abertas concedidas durante a feira, no dia 30 de janeiro de 2016.

${ }^{27}$ Entrevista concedida no dia 30 de janeiro de 2016.
} 
venda no cotidiano. Contudo, essa forma costuma ser casual, aumentando a frequência com a chegada de épocas festivas. Muitos assentados que trabalham fora ou são aposentados e possuem pequenas produções para uso doméstico fazem esporadicamente esse tipo de venda para complementar a renda.

O encontro físico entre o consumidor e o produtor no lote permite um dialogo sobre experiências e conhecimentos culturais entre as partes. Os laços sociais são fortalecidos, nesta forma de comercialização, pelo conhecimento que o consumidor adquire da origem do produto e da realidade de vida do produtor, facilitando o encontro de um preço justo entre os dois. Observou-se que não raro são praticadas pequenas doações e trocas não mercantis, como a doação ou troca de sementes, de mudas e outros recursos. São dádivas ao mesmo tempo materiais e simbólicas que conferem a agregação de uma relação de reciprocidade (binária de tipo "cara a cara") a relação de troca mercantil. Essas relações de reciprocidade como em qualquer outra situação de venda direta, geram valores afetivos entre produtor e cliente.

Os produtos mais procurados são hortaliças, mandioca, galinha caipira, ovos, pequi, buriti e outros produtos extrativistas. A venda de produtos agropecuários e extrativistas em maior escala no próprio lote é orientada para atravessadores e intermediários. Para esses casos seguem tópicos específicos.

\subsubsection{Venda do lote para intermediários e atravessadores}

Constatou-se em campo que o intermediário, que diferenciamos do atravessador, em geral se caracteriza por manter uma relação de proximidade e até de reciprocidade com o produtor, estabelecendo uma negociação do preço e transparência sobre o destino do produto. Ou seja, o produtor sabe para onde seu produto vai e quem recebe este produto sabe de sua procedência. $\mathrm{O}$ atravessador é um tipo específico de intermediário, uma figura historicamente construída. Contudo, este se caracteriza por não estabelecer uma relação de proximidade com o produtor e, geralmente, não negociar preço. 
No PA Cynthia Peter, J. vende em média 400 litros de pequi para O., durante toda a safra. J. sabe o nome e a localidade da agroindústria para onde vão seus produtos e como eles serão processados. Assim como a agroindústria sabe a procedência do produto e seu dono pode confiar na qualidade dos produtos segundo sua origem, Para $\mathrm{J}^{28}$, seu comprador não é um atravessador convencional:

\begin{abstract}
"Acho ele assim, tipo um atravessador, mas melhor que os outros, é diferente. Já negociei com ele. (...) Temos uma amizade, (que) faz a gente ter confiança. Com os outros não tem negociação e nem confiança. Não é contrato, mas todo ano ele pega (compra) na nossa mão (...). Ele (o pequi) é industrializado lá mesmo aonde ele tem o galpão (Goiânia) e exporta para São Paulo" (J., Entrevista, 27 de janeiro de 2016)
\end{abstract}

Essa relação de tipo "cara a cara" existente entre produtor e intermediário permite o diálogo e traz simpatia e logo amizade que geram confiança entre as partes, fazendo com que $\mathrm{J}$. trabalhe mais seguro, sem medo de não conseguir vender.

A relação entre produtor e intermediário de tipo "cara a cara" pode ser mais ou menos equilibrada ou simétrica, mas em muitos casos permanece assimétrica. Ou seja, envolvendo certo nível de submissão ou obrigação do produtor em relação, por exemplo, ao processo de negociação do preço ou à exigência de determinada quantidade produzida ou vendida. Contudo, esta forma comercial necessariamente envolve relações de proximidade e diálogo, permitindo minimizar a tensão existente na dominação da relação de troca mercantil sobre as relações e práticas de reciprocidade.

$\mathrm{Na}$ venda para atravessadores existe a dominação do princípio da troca baseado no interesse individual pela obtenção do lucro máximo, sem associação de nenhuma dimensão de reciprocidade. O medo e a insegurança permeiam a vida dos assentados em Mambaí que praticam o extrativismo

\footnotetext{
${ }^{28}$ Entrevista concedida no dia 27 de janeiro de 2016.
} 
vendendo para atravessadores. Para além da relação de submissão do produtor aos interesses do atravessador, existe também o descaso e 0 desrespeito: em muitos casos o atravessador passa nos lotes falando que vem comprar em alguns dias as conservas de pequi ou outros produtos e nunca aparece para efetuar a compra. Os atravessadores avisam todos do assentamento que virão comprar, mas acabam comprando somente de alguns. Certos atravessadores pegam os produtos e pagam meses depois.

$\mathrm{Na}$ venda do pequi, que é feita majoritariamente para atravessadores, existem dois principais tipos de atravessadores. Um deles possui um contrato informal com agroindústrias que pagam ao atravessador em média 20 centavos por litro de polpa de pequi, em média. Outro é aquele que trabalha de forma independente com o seu próprio capital financeiro e negocia diretamente com agroindústrias, feirantes ou cooperativas.

As agroindústrias da região extraem o óleo do pequi e processam molhos e outros derivados. Existem agroindústrias comprando diretamente da mão do extrativista como, por exemplo, o Empório do Cerrado, muito atuante na região. Outro exemplo é a agroindústria familiar Beco da Mata. Esta foi recentemente inaugurada e se localiza na cidade de Mambaí, desenvolvendo compras diretamente do lote do agricultor.

O pequi não é muito vendido pelos extrativistas em feiras locais, de porta em porta, na rua e por encomenda porque a região possui muita abundância dessa árvore e todos conseguem gratuitamente seus frutos. Porém, em épocas fora da safra, os produtos derivados do pequi estão começando a ter mais valor nestes mercados curtos de proximidade. Estes outros derivados são a castanha, a farofa e o óleo de pequi, que podem ser produzidos de forma artesanal. 


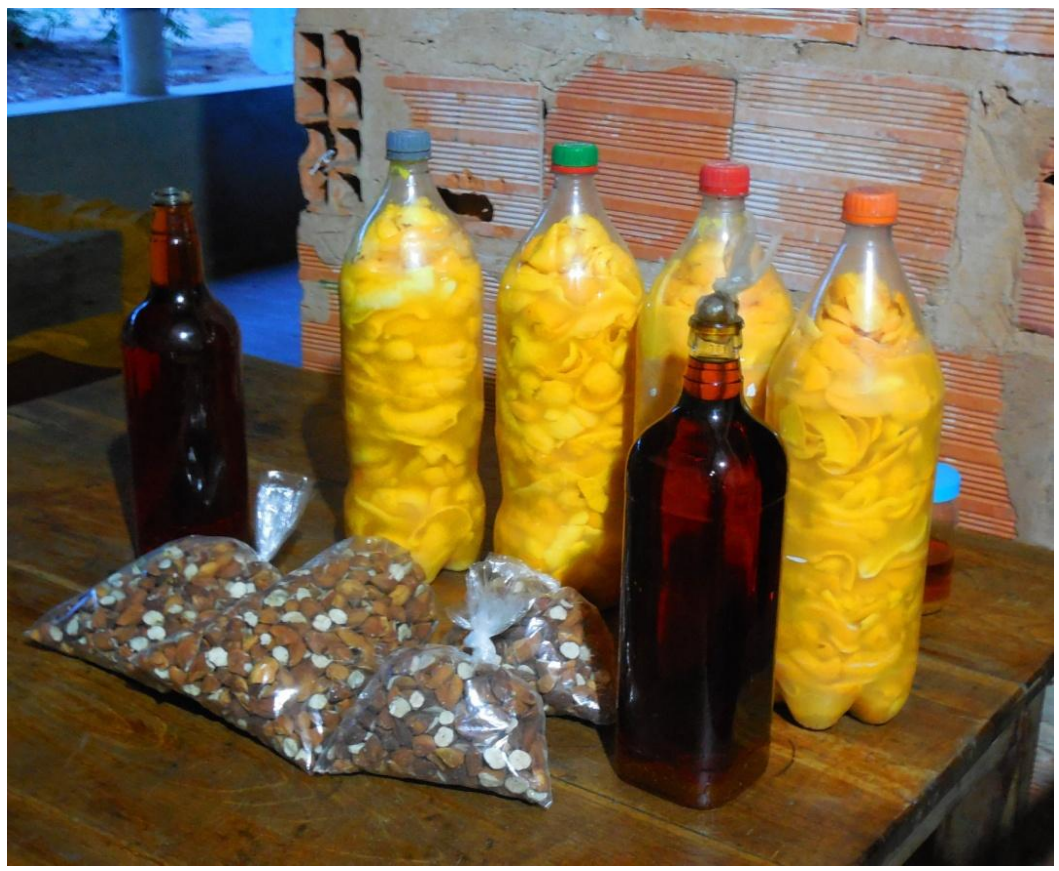

Figura 7: Derivados do pequi: polpa em conserva, óleo e castanhas. Trabalho de campo. Mambaí, 2016. Foto: Igor Aveline.

Em média, o quilo da castanha de pequi está sendo vendido por 20 reais e o óleo de pequi por 50 reais o litro. Contudo, identificamos que menos de $10 \%$ deles buscam vender o pequi fora da época de safra como estratégia de venda, mesmo sabendo que sua demanda e valor são mais altos nestes períodos, tanto na venda direta como na venda indireta.

Segundo Au., "Para conseguir uma boa margem de lucro é necessário conseguir um bom comprador". Para ela, a comunidade do assentamento Agrovila do Funil está cansada de receber cursos (citou: Embrapa, Sebrae, Senar e Conab) que ensinam “(...) as técnicas como se fossem fáceis, mas não conhecem nossa realidade. Agente sabe fazer (dentro dos modelos e padrões de qualidade ensinados), mas não sabe pra quem vender (nestes formatos)". Sendo assim, continuam vendendo o pequi despolpado em conservas de garrafa pet, formato como os seus maiores consumidores (os atravessadores) procuram. O desafio está em promover novas formas de comercialização que permitam a venda do pequi com maior valor agregado de qualidade e origem. Enquanto isso, Ca. (PA Agrovila do Funil) e outros agricultores aguardam a chegada dos atravessadores. 


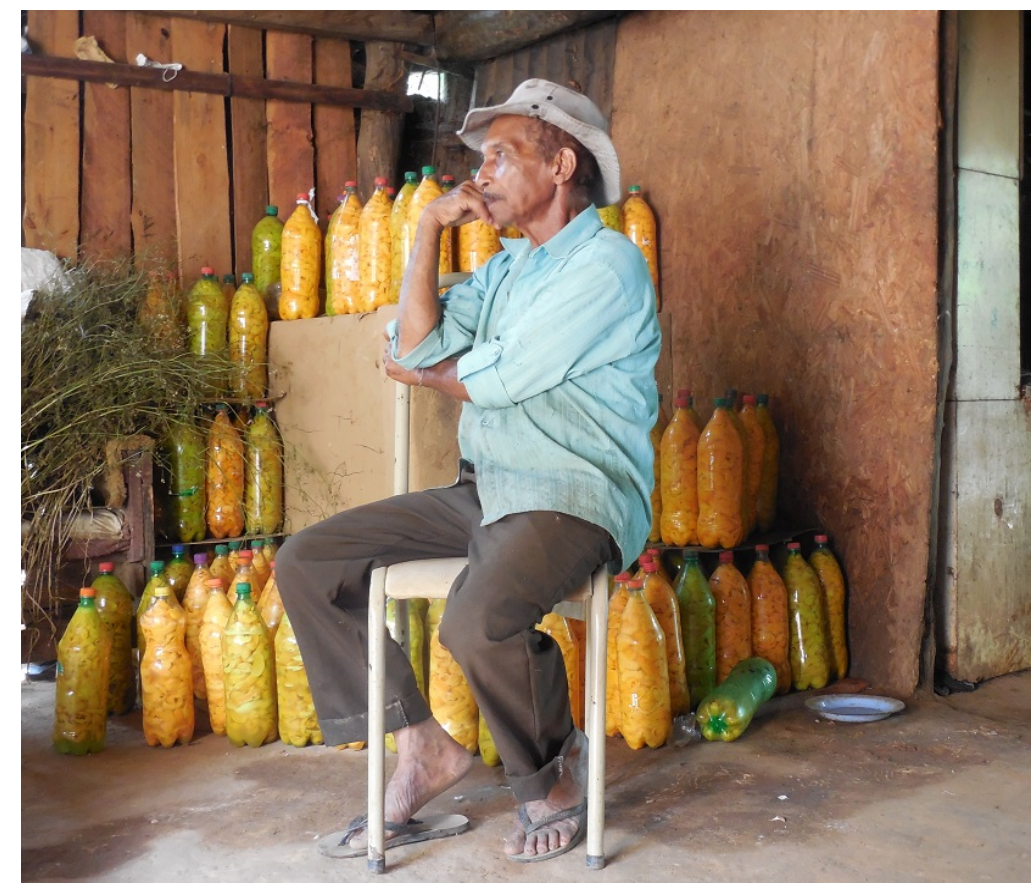

Figura 8: C. aguarda atravessador. Trabalho de campo. Mambaí, 2016. Foto: Igor Aveline.

O intermediário pode ser um conhecido, um amigo, alguém que está retribuindo um favor outrora concedido pelo produtor ou até mesmo alguém contratado, formal ou informalmente. G. relatou vender seus produtos no CEASA por meio de amigos e conhecidos de confiança que lhe devem favores. Por vezes combinava o valor do transporte, ou pagava somente o combustível. Com a nova feira, passou a vender melancia todo sábado para um intermediário que revende seus produtos. Segundo ele, este não nega a origem dos mesmos para os mais curiosos. G. está satisfeito com o preço pago, mas está ansioso para ter sua própria caminhonete para vender na feira e em outros lugares. Na relação com o intermediário existe o diálogo, a negociação e 0 acordo de um preço que tende a ser mais justo.

Joc. (PA Cynthia Peter) falou que poderia processar o pequi e vender para os mercados locais, mas é impedido pela exigência de um padrão sanitário específico e por não emitir nota fiscal (não ter DAP). Este caso é parecido com o de J. (PA São José). A dificuldade de se enquadrar às exigências legais obriga este agricultor a vender carne bovina e suína para atravessadores e para açougues clandestinos via intermediários. Segundo J., por sorte ele consegue vender algumas galinhas por encomenda no dia a dia, com segurança e recebendo melhor. 
Va. e Vi. (PA São José) são dependentes do atravessador na venda de frutas e verduras quando estão tendo uma alta na produção no momento de pico da sua safra e não conseguem vender tudo que gostariam na feira ou de porta em porta. Nesta situação, o atravessador é procurado para conseguir vender $\mathrm{o}$ excedente e não perder a produção. Estes dois agricultores representam um caso típico de agricultores que conseguem diversificar sua produção tanto como suas formas de comercialização. Sendo assim, apesar de priorizarem a venda de verduras na feira, eles preferem produzir ainda outra cultura especificamente para a venda para atravessadores. Por exemplo, no caso do milho Va. busca vendê-lo "em pé". Ou seja, Va. prefere firmar acordo informal de venda do milho para atravessadores antes mesmo de colhê-lo. Assim, garantem uma renda extra a partir de uma produção que não exige muito trabalho, tanto de produção quanto de venda.

Como vimos nos exemplos, a legislação sanitária contribui para a manutenção da informalidade que, nos casos das vendas indiretas, fortalecem a dependência dos agricultores em relação aos atravessadores, estimulando $O$ contato desses agricultores com agroindústrias e comerciantes ilegais. A falta de transporte público especializado e particular e a grande distância entre a maioria dos assentamentos e seus possíveis consumidores também impedem alguns agricultores de sonhar em vender na cidade de forma independente. Alguns encontram solução em caronas solidárias, fretando carros ou usando o transporte público (ônibus escolar) para levar seus produtos diretamente ao consumidor final.

A venda para atravessadores varia muito, ocorrendo geralmente de forma esporádica nos picos da safra. A venda via intermediário, por compreender volumes e tipos de produtos mais variados, costuma ser desenvolvido com mais frequência. $O$ preço na relação comercial com 0 intermediário, como vimos, tende a alcançar um valor mais justo por envolver a proximidade e acordos negociados entre as partes. Assim como as relações de reciprocidade simétricas permitem a geração de valores de amizade e confiança mútua, conferindo segurança e perenidade à relação de mercado. A troca de contatos pessoais e a negociação da relação de troca se configuram como práticas sociais estruturantes da forma de venda para intermediários. 


\subsubsection{Venda na meia: a reinvenção do intermediário}

A venda na meia se configura como uma prática mobilizada em diversas situações e percebida de diferentes maneiras pelas famílias assentadas em Mambaí. A venda na meia acontece quando um agricultor delega à um colega a comercialização de seus produtos segundo o acordo informal de receber em troca a metade do valor adquirido na venda dos mesmos. A venda na meia se caracteriza como uma venda para intermediário, pois existe um conhecimento mútuo entre produtor e vendedor e um acordo sobre a origem, o destino e o preço dos produtos.

Au. (PA Agrovila do Funil), por exemplo, desenvolve a venda na meia com seu vizinho, Jo. Ela mobiliza essa estratégia por não ter transporte particular. Assim, Jo. passa no lote de Au. para pegar as hortaliças e vender na cidade de porta em porta ou complementar suas vendas por encomenda. Quando Jo. volta ao assentamento, retorna à casa de dona Au. para deixar metade dos ganhos com os produtos. Segundo Au., a venda na meia é um "gesto de solidariedade e companheirismo", pois o lucro é pouco tanto para quem produz quanto para quem vende. A venda na meia serve para permitir quem não tem transporte e outras formas de escoar a produção superem a dependência de um atravessador e não tenham prejuízos, explica Au.

Jo. ajudou vários agricultores do assentamento Agrovila do Funil vendendo seus produtos na meia, principalmente quando ele mesmo estava com baixos níveis de produção e queria manter o abastecimento dos seus clientes. Esta prática foi considerada por Er. e Ap. como uma grande ajuda, independentemente do preço poder aparecer injusto para o produtor. Segundo Ap., o combustível é caro e se gasta muito tempo no deslocamento e na venda. "A venda na meia é justa, ele também tem que ganhar".

Ap. (PA Cynthia Peter) teve um acidente vascular cerebral (AVC), parando de trabalhar fora do lote. Com o acidente teve que ficar em casa e dispôs seu tempo para plantar hortaliças. Rapidamente Ap. começou a ter excedentes e vender pequenas quantidades para a família e conhecidos. Foi 
neste momento que Jo., do assentamento vizinho, lhe ofereceu vender seus produtos na meia. Ap. não podia dirigir e atribui à venda na meia o seu aprendizado da comercialização e o início de sua nova carreira e seu sucesso atual como produtor de folhosas Hoje, Ap. vende na meia para dois outros agricultores do assentamento vizinho, quando eles precisam.

A venda na meia é frequentemente mobilizada quando um agricultor precisa ficar no assentamento para vigiar a produção, pela necessidade de um manejo urgente do gado ou para semear uma nova área sem poder sair para vender sua produção. Na maioria das vezes essa prática ocorre em casos de necessidade, como forma de garantir que algum agricultor não tenha perdas ou prejuízos com a produção ou comercialização.

Como esta estratégia se da sempre entre pares de produtores vizinhos ou próximos, essa prática configura mais um exemplo de ajuda mútua, quer dizer de relação de reciprocidade binária de tipo "cara a cara", associada a uma transação de troca mercantil. Esta estratégia tem contribuído para facilitar o acesso ao mercado de agricultores dos assentamentos e em certos caso como Ap., o acesso a aprendizagem da comercialização baixo a tutela de Jo.

A venda na meia representa uma prática de troca mercantil facilitada ou até possibilitada pela agregação de uma relação de reciprocidade binária que pode ser mais ou menos simétrica. Nestes casos observamos a priorização da relação de solidariedade sobre o interesse do lucro na relação de troca. Ou seja, independente do custo de produção e de venda dos produtos, os ganhos são repartidos pela metade entre as partes envolvidas no intuito de perpetuar aquela relação de ajuda mútua.

\subsubsection{Venda para pequenos mercados e supermercados}

Foram entrevistadas, durante a pesquisa exploratória, 32 famílias assentadas que produziam e comercializavam. Destes, somente 5 agricultores assentados em Mambaí declararam vender para pequenos mercados locais ou supermercado, mobilizando uma ou as duas formas comerciais. Cada agricultor descreveu uma relação diferente com estes mercados. 
Va. e dona M. (PA São José) disseram privilegiar a venda na feira, depois tentam vender o que sobrou na rua e de porta em porta e, por fim, tentam vender em supermercados. L. (PA Agrovila do Funil) prefere vender somente aos supermercados da região e diz não gostar de gastar tempo vendendo em pequenas quantidades em mercados locais de venda direta. Ma. (PA Cynthia Peter) vende esporadicamente a farinha de mandioca para supermercados, quando não consegue vender toda a produção para conhecidos de porta em porta na cidade. Ap. e Joc. (PA Cynthia Peter) privilegiam a venda nos dois pequenos mercados de Mambaí (Sacolão e Verdurão) e vendem de porta em porta ou por encomenda o excedente.

Joc. justificou sua preferência em vender para a loja Sacolão porque consegue fornecer regularmente ( 3 vezes por semana) uma quantidade maior de produtos (mandioca, abóbora e batata doce) mesmo recebendo menos que na venda direta ao consumidor. Ap. produz hortaliças, principalmente alface e cheiro verde, e entrega todos os dias da semana e justificou sua preferência da mesma maneira. Vendendo por encomenda eles ganham mais por produto, mas perdem tempo fazendo as entregas. Joc. espera poder vender também na feira de Mambaí, com o aumento das suas colheitas. Segundo ele, com a feira, tem grandes esperanças de uma melhora de vida.

Os donos dos pequenos mercados e supermercados locais compram a maior parte de seus produtos no CEASA de Brasília, a 308 quilômetros de distância de Mambaí. Alguns admitem saber que determinados produtos que compram no CEASA são produzidos em Mambaí, por agricultores familiares. Mas, segundo eles, preferem comprar tudo em um só lugar. Somente as hortaliças folhosas são compradas dos agricultores locais, por elas não resistirem a longa viagem de Brasília à Mambaí.

Os supermercados e pequenos mercados de Mambaí, na prática, não firmam contratos formais com os agricultores familiares. O fornecimento é na base da confiança. Segundo L., ele possui "praticamente um contrato", pois tem anos que vende para o mesmo estabelecimento e existe muita confiança recíproca. Os donos dos supermercados disseram trabalhar em "regime de lucro real" que exigem nota fiscal dos agricultores, pois precisam comprovar 
tudo que compram e vendem. Contudo, hoje nenhum agricultor em Mambaí possui direitos legais para emitir nota fiscal e as partes (produtores e donos dos mercados) costumam negociar alguma forma para efetivar a transação comercial. Nestas negociações o agricultor costuma ficar em desvantagem por estar em uma posição vulnerável. Os acordos são de pagamento em dinheiro com redução de preço dos produtos ou disponibilizando crédito para o agricultor consumir produtos do próprio mercado.

A dona do único supermercado de Mambaí (Brunatto) demonstrou interesse em começar a comprar produtos dos agricultores e contribuir com o desenvolvimento da região. Ela relatou que os produtos que vendem no supermercado são produzidos com muito agrotóxico e que ela mesma compra na nova feira do agricultor familiar os produtos para seu consumo pessoal. Segundo os donos dos estabelecimentos Sacolão, da pequena verduraria (sem nome) e do supermercado Brunatto, além da falta de DAP dos agricultores locais, a falta de regularidade e o volume de produção também dificultam consolidar alguma forma de contrato com esta categoria de fornecedores.

Segundo Va., quanto maior e mais influente o supermercado, menos é possível negociar o valor dos produtos. Va. produz algumas culturas (melancia, coco e cítricos) em maior escala destinadas à venda para atravessadores ou supermercados; quando não consegue mais vender toda a produção nas feiras, de porta em porta e na rua. Por priorizar a comercialização em circuitos curtos de proximidade, Va. não possui regularidade no fornecimento para supermercados e os valores dos produtos não são previamente negociados.

$\mathrm{Na}$ venda para pequenos mercados em Mambaí, os agricultores recebem somente quando é finalizada a venda de seus produtos nas prateleiras do mercado. Segundo acordos informais, os donos dos estabelecimentos fazem o pagamento segundo a quantidade de produtos vendidos e não se responsabilizam por produtos que não foram comprados. Ou seja, o agricultor não recebe por produtos que não forem comprados pelos usuários do mercado.

Tanto nos pequenos mercados quanto nos supermercados observamos relações sociais de proximidade e de respeito mútuo entre os donos, 
empregados do estabelecimento e os produtores fornecedores. A este fenômeno podemos atribuir a existência de relações de proximidade próprias das cidades pequenas, que acabam permeando todos os âmbitos da vida local. Dois dos agricultores entrevistados que vendem para estes estabelecimentos estavam tendo problemas em suas produções. Ao entrevistarmos os donos dos estabelecimentos, perguntamos se eles sabiam das dificuldades que seus fornecedores estavam passando. As respostas foram precisas, comprovando essa relação de proximidade. Segundo a responsável por um dos estabelecimentos, em relação à seu fornecedor: "Eu conheço a família dele toda. Aqui todos se conhecem e sabem das coisas que acontecem (...)"29.

A proximidade entre duas partes pelo contato direto, envolvendo 0 diálogo e a criação de laços, é característica de uma relação de reciprocidade binária de tipo "cara a cara" que também vem se agregar a relação de troca mercantil. A criação e manutenção dessa relação de reciprocidade geram respeito mútuo, simpatia e até confiança que contribuem para a perenidade da relação mercantil.

Contudo, observamos ainda, de forma concomitante, a submissão do agricultor em relação ao preço determinado sem negociação pelo comerciante e pela obrigação deste em receber a prazo ou em créditos em produtos do próprio estabelecimento. Estas práticas podem se caracterizar também como relações de reciprocidade binária assimétricas, ou como relações de reciprocidade no plano social, que facilitam a aceitação da assimetria no plano da troca mercantil, ou seja, a exploração econômica.

\subsection{Articulação entre diferentes formas de comercialização}

Durante a pesquisa se confirmou a existência de agricultores de diferentes perfis e disposições em praticar, de maneira conjunta e articulada, diferentes formas de comercialização. Certos agricultores preferem vender tudo de uma vez para grandes mercados locais ou atravessadores, por meio de contratos informais que garantam o rápido e fácil escoamento de sua produção,

\footnotetext{
${ }^{29}$ Entrevista concedida no dia 27 de janeiro de 2016.
} 
normalmente em monocultura. Estes sustentam o ônus do baixo preço das grandes vendas em atacado pelo tempo ganho para outros empreendimentos na produção. Outros, com menor escala e tamanho de produção, buscam preços melhores e valorizam socialmente o contato com o consumidor e as relações de reciprocidade desenvolvidas nas praticas de venda direta para assegurar a manutenção de relações pessoalizadas de fidelidade com os seus clientes.

L. produz somente alface e couve e focaliza suas vendas para supermercados, entregando quase todos os dias da semana. Contudo, faz vendas por encomenda para conhecidos quando sobram produtos. Segundo este agricultor, ele não gosta de "(...) gastar tempo vendendo em feira ou na rua, essa gente negocia demais. (...) Não posso ficar vendendo fiado”. Apesar de admitir que ganharia mais vendendo diretamente para o consumidor, ele prefere vender para o supermercado buscando produzir em larga escala. Va. (PA São José) relatou o oposto. Este prioriza a venda na feira, pois ganha mais, encontra os amigos e ganha prestígio na cidade.

Da mesma forma, cada agricultor articula de forma particular suas diversas formas de comercialização. Retomemos o exemplo de VA. Ele segue uma lógica de priorização das formas de venda: primeiro tenta vender 0 máximo na feira, depois vende de porta em porta e na rua (ao mesmo tempo) e, se sobrar produtos, tenta vende-los nos supermercados. Va. ainda produz certos cultivos para vender periodicamente para atravessadores. De forma geral, existe uma priorização de cada uma das opções comerciais segundo diferentes fatores. A relação entre o preço pago pelos produtos e o tempo de dedicação para vendê-los os principais fatores.

Para alguns agricultores dizer qual é a melhor forma de venda não faz sentido, pois a melhor estratégia é não depender apenas de uma só forma de comercialização. Segundo Ap., é muito interessante o agricultor ter diversas formas de escoar sua produção para jogar sobre a complementaridade e a diversidade da demanda e da oferta. Para Vi., cada forma de venda serve a um momento da sua produção e da demanda dos mercados locais. Se a demanda estiver alta, ele vende na feira. Mas se houver muita oferta de um produto 
(geralmente no auge da safra) e não conseguir vender na feira, ele vende para atravessadores. M. (PA São José) também comentou os benefícios de ter diferentes alternativas de venda para cada produto. Além de produzir uma gama variada de produtos para a venda na feira, ela também vende a melancia e o milho do próprio lote para atravessadores. Assim, segundo ela, de tempo em tempo consegue complementar a renda com culturas em maior escala que exigem menos tempo de cuidado e manejo no dia a dia. Contudo, vale ressaltar que a eficácia dessa estratégia de diversificação vai depender do perfil do próprio agricultor e de sua capacidade de administração e distribuição da produção e da sua comercialização.

Constatamos que o agricultor que diversifica a produção tende logo a diversificar as formas de comercialização e, por consequência, a ter mais facilidade de buscar alternativas frente aos desafios cotidianos. Produzir mais de uma cultura e integrar funcionalidades complementares à paisagem do lote (e do assentamento) contribui à segurança alimentar da família devido ao aumento da estabilidade econômica e da resiliência ambiental local. Esta situação confere mais controle e mais autonomia ao agricultor e aumenta sua capacidade de buscar as melhores formas de venda, negociar o preço de seus produtos e aguardar o momento mais oportuno da venda. Logo, a segurança alimentar da família influencia diretamente o planejamento familiar da produção e da venda, conferindo um planejamento a longo prazo e a possibilidade de articular formas mais complexas e rentáveis de comercialização.

Notamos que para produtores de maior escala, a relação social de reciprocidade torna-se com o tempo e o crescimento da atividade comercial, cada vez mais uma forma de manutenção da clientela, e não tanto uma necessidade estratégica para construir e acessar mercados locais e regionais.

É importante a observação de agricultores como F., Au., E Jo. (PA Agrovila do Funil). Estes disseram estar substituindo a venda por encomenda pela venda na feira, mas que se esta última parasse por algum motivo de funcionar eles conseguiriam facilmente voltar a vender por encomenda. A venda por encomenda possui esta característica de resiliência por ser a forma de comercialização com relações de reciprocidade mais intensas e constantes 
entre vendedor e consumidor. Além disso, na feira, os agricultores estão acessando os mesmos clientes que tinham na venda por encomenda e permanecem reproduzindo laços de confiança e amizade entre eles, facilitando essa flexibilização das formas de venda. A venda de porta em porta e na rua também possuem tal capacidade de voltar facilmente a ser mobilizada, mas principalmente por serem informais.

A carona solidária e a venda na meia são práticas de reciprocidade mobilizadas para acessar quase todas as formas comerciais acima descritas, exceto a venda para atravessadores. Os mutirões e as troca de serviços entre produtores sem câmbio monetário estão presentes nas mais diversas situações produtivas e favorecendo o acesso aos mercados locais. Observamos que a venda fiado é mobilizada somente na venda de porta em porta e por encomenda, sendo raramente mobilizada na feira. Quando esta prática é mobilizada na venda de porta em porta, confirmando compromissos, ela tende a fortalecer a confiança e, por fim, contribuir à sua transformação para uma venda por encomenda. 


\section{ANÁLISE E DISCUSSÃO}

Neste capítulo analisamos as relações e práticas de reciprocidade associadas às diversas formas comerciais mobilizadas por agricultores familiares assentados em Mambaí e seu papel na consolidação e sustentação dessas estratégias comerciais discutindo os resultados da pesquisa.

Concordamos, na presente pesquisa, com a tese de Van Der Ploeg (2008) de que, apesar do contexto desfavorável, a pequena agricultura local de caráter familiar consegue diversificar suas formas de produção e comercialização e manter práticas distintas daquelas orientadas unicamente pela lógica capitalista do mercado de troca. As formas comerciais promovidas por assentados rurais em Mambaí são obviamente motivadas pela necessidade financeira e por uma lógica de troca mercantil, mas ultrapassam a lógica de mercado fundada somente pelo interesse monetário individual. De fato eles agregam relações de reciprocidade de natureza social e também econômica e material que permitem a construção e a manutenção de suas relações de troca mercantil.

Identificamos diferentes relações de reciprocidade simétricas, ou equilibradas, associadas às diversas formas de comercialização. Essas relações de reciprocidade são principalmente práticas de ajuda mútua, de repartição de produtos e de partilha de recursos (excedentes e informações). Estas relações estruturam diversos âmbitos da vida rural e do processo social de construção de mercados protagonizados por agricultores assentados em Mambaí.

Dentre as práticas de reciprocidade mobilizada entre os agricultores podemos destacar a carona solidária, a "troca" de produtos e nichos de mercado, a partilha de saberes, a divulgação cruzada de produtos, a venda fiado e a venda na meia. Entre produtores e consumidores/clientes identificamos, em meio a relação de troca mercantil, as relações de reciprocidade binária de tipo "cara a cara" ligadas a venda direta ao 
consumidor. Estas se traduzem por tratamentos pessoalizados específicos e pela venda fiado.

\subsection{Relações de reciprocidade entre agricultores}

\section{a) As práticas de ajuda mútua}

A ajuda mútua se configura como uma forma de organização do trabalho baseada na cooperação e na reciprocidade dos serviços prestados mutuamente, sem implicar em retribuição equivalente (MAYER apud SABOURIN, 2011). Práticas de ajuda mútua em Mambaí são a carona solidaria e a venda na meia. Essa última é uma prática comum mobilizada por pares de agricultores quando uma das partes não pode (ou não quer) vender seus produtos e o outro tem o interesse em incrementar suas vendas. O primeiro garante o escoamento de sua produção e o segundo completa ou complementa os produtos que almeja vender para satisfazer seus clientes e incrementar sua renda. Existem outras situações variantes em que a venda na meia é usada.

Os agricultores Jo., Au., Ap. e Er. e Vi., de vários assentamentos, descrevem a venda na meia como uma forma de ajuda mútua. Ela é considerada assim por reunir duas partes que se precisam mutuamente para completar o ciclo de produção e venda. Outros agricultores, como Va. (PA São José), descrevem como uma parceria injusta para o produtor. Independente das noções de justiça e solidariedade descritas pelos agricultores, observamos que esta prática ajudou muitos agricultores em momentos de vulnerabilidade, em que poderiam perder a produção por falta de transporte ou local de venda.

É na confirmação da prática de ajuda mútua, ao longo do tempo, que os laços mútuos de confiança e parceria se concretizam, assim como as obrigações éticas intrínsecas a mesma. Segundo dona Jo. (PA Agrovila do Funil), seu marido vendeu na meia durante muito tempo para o seu vizinho Ap. Este teve AVC e não podia sair do lote para comercializar. Segundo Jo. "(...) agora eles (Ap. e seu marido) são igual irmão. Pra tudo eles se ajudam. Ap. 
não precisa mais de ninguém pra vender na meia, mas eles continuam sempre se ajudando".

Apesar dos interesses em benefícios monetários, intrínsecos a qualquer relação de troca mercantil, observa-se na venda na meia a reprodução social de uma prática em que o preço (o valor a ser pago pelo produto) não é a questão mais relevante na relação de troca. Isso fica claro quando os agricultores não demonstram preocupação em cobrar mais caro se a produção de alface the demandou muito mais trabalho que a produção de rúcula, por exemplo.

As relações de reciprocidade binária simétrica de tipo "cara a cara" são facilmente identificadas nesta prática, principalmente quando os agricultores comentam sobre a legitimidade da forma de repartição dos ganhos: uma divisão igualitária do valor pago pelo produto, independente dos custos de produção, transporte e comercialização. Aquela legitimidade foi quase sempre esclarecida pelos entrevistados a partir do direito de ambas as partes a compartilhar dos ganhos de maneira equitativa. No discurso de cada um está a priorização da importância da reprodução desta parceria em relação ao interesse individual pelo lucro.

A venda na meia, como vimos, tem ajudado na manutenção do agricultor no campo por meio de estratégias fundadas na reciprocidade, acessando oportunidades de mercado segundo práticas que superam a supremacia das relações sociais fundadas na lógica do lucro individual e imprimem senso de igualdade e justiça às relações de mercado. O agricultor J. (PA Cynthia Peter) elucida bem a geração deste valor de justiça em sua argumentação: "O preço pode parecer injusto para o agricultor (na venda na meia), mas ajuda muito. 0 petróleo (combustível) é caro e eles gastam tempo pra vender. (...) A venda na meia é justa, eles também tem que ganhar".

A carona solidária é a prática de reciprocidade mais frequente que identificamos em Mambaí, caracterizada como uma dádiva unilateral, se não houver retribuição, ou como uma troca, se houver algum tipo de retribuição ou pagamento. No caso de Jo. (PA Agrovila do Funil), esta forma de solidariedade é reproduzida principalmente com Au. e sua irmã. As duas não possuem 
transporte e precisam ir periodicamente à cidade fazer entregas. Neste caso, Jo. transporta os produtos de Au. e de sua irmã sem cobrar nada ou, por vezes, pedindo uma ajuda no combustível. Au. declarou que, se não fosse a solidariedade de Jo., perderia parte de sua produção e deixaria de vender suas hortaliças por encomenda.

No assentamento São José, identificamos que o único agricultor que possui veículo apropriado para o transporte de mercadorias é Va. Assim, muitos produtores dependem do mesmo para vender seus produtos. Segundo técnico da EMATER-GO, o PA São José é o assentamento mais desenvolvido da região por conta da atuação de liderança do casal Va. e M. Tanto pela constante ajuda oferecida em caronas solidárias, trocas não mercantis, como pelo exemplo de superação e força de vontade do casal de agricultores.

Vale discorrer ainda sobre outras duas formas de ajuda mútua que se reproduzem diariamente entre agricultores dos assentamentos de Mambaí, mesmo não estando relacionadas diretamente às estratégias comerciais dos mesmos, mas a produção e a distribuição dos excedentes. Elas são a troca de serviços e o mutirão $0^{30}$. Este é cada vez mais raro, segundo relatos dos produtores locais. Contudo, a troca de serviços entre pares continua muito presente. Por exemplo, quando um agricultor precisa vacinar um gado e chama o vizinho para the ajudar, ou para qualquer trabalho de construção de casa, local de criação ou estufas. No dia seguinte quem recebeu a ajuda vai ao lote do outro ajudá-lo. Segundo os agricultores a troca de serviços gera laços de cooperação, de confiança e até de amizade.

Podemos observar que as práticas de venda na meia são relações de reciprocidade binária, desenvolvidas somente entre pares de indivíduos ou famílias. Outras práticas de solidariedade são compartidas indiferentemente entre vários membros do assentamento ou do grupo social. Dentre estas praticas de compartilhamento de recursos identificamos a partilha de saberes e informações, a partilha de excedentes produtivos, assim como determinadas

\footnotetext{
${ }^{30}$ Mutirão “(...) designa dois tipos de cooperação camponesa de origem autóctone. A primeira diz respeito aos bens comuns e coletivos (construção ou manutenção de uma rodovia, escola, barragem ou cisterna), a outra aos convites para trabalhar em benefício de uma família, em geral para trabalhos penosos (...)" (SABOURIN, 2011: 63).
} 
caronas solidárias desenvolvidas para pessoas da comunidade sem acordo prévio e a divulgação cruzada, como analisamos a seguir.

\section{b) As práticas de compartilhamento de recursos}

O principal recurso compartilhado entre os agricultores voltado à comercialização é o saber técnico ou prático para produzir um excedente comercializável. Segundo o técnico da EMATER-GO, o assentamento São José praticamente não recebeu assistência técnica em toda sua história e o papel de liderança de Va. e M. foi fundamental para o desenvolvimento do assentamento:

“(...) lá quase não teve assistência técnica. Foi liderança deles mesmo. Eles (Va. e M.) começaram a produzir e os outros foram vendo e aprendendo. Não foi assistência, foi experiência deles mesmo. Eles são mais unidos e se ajudam" (Entrevista concedida em 07 de novembro de 2015).

Este e outros casos descritos em outros tópicos demonstram a capacidade de ação e o papel de uma liderança no desenvolvimento de uma comunidade unicamente a partir da sua disposição em compartilhar seus recursos e conhecimentos por solidariedade econômica com os seus pares dos assentamentos, em lugar de desenvolve-los como um atributo individual para superá-los na concorrência comercial ou na competição produtiva;

A partilha de produtos para ajudar na comercialização e evitar perdas responde a mesma lógica da relação de reciprocidade binária do subtipo compartilhamento de recursos. A lógica desse tipo de relação estruturada pode ser ilustrada pelo lema "Um por todos, todos por um", mesmo se este "todos" correspondem a um grupo social delimitado de pares: assentados do mesmo PA ou dos PA's vizinhos. 
Existem dois tipos de partilha de produtos em Mambaí. Uma é a "troca" ou repartição de produtos, e a outra é a doação de excedentes. A repartição de produtos ocorre quando um agricultor tem uma redução em uma de suas produções e, para continuar assistindo seus clientes, busca outro produtor para Ihe ajudar partilhando ou "trocando" parte de sua produção. A repartição, neste caso, é caracterizada quando um agricultor já possui formas de vender seus produtos, mas os encaminha para outros agricultores como forma de ajuda-los. Os produtos repartidos podem ser recompensados de forma monetária ou não monetária, por meio de trocas ou futuras parcerias. Muitas vezes o valor dos produtos é transferido integralmente para 0 agricultor que repartiu seus produtos ou é feito o acordo da venda na meia.

A doação de excedentes não está envolvida diretamente nos processos comerciais, mas merece aqui um destaque. Esta prática foi identificada em várias situações durante a pesquisa, pois está presente de forma expressiva no cotidiano dos agricultores em Mambaí. Geralmente, o agricultor oferece seus excedentes quando recebe uma visita ou procura algum conhecido nos arredores para fazer a partilha dos seus excedentes. Esta forma de reciprocidade confere prestígio ao agricultor e fortalece laços de amizade dentro da comunidade.

Identificamos ainda relações de compartilhamento de pontos de entrega por encomenda e locais de venda como tendas na feira e prateleiras de pequenos mercados. Au. (PA Agrovila do Funil), por exemplo, estava com um ponto de venda de doces na feira e, ao mesmo tempo, vendia outros produtos, como hortaliças e galinha caipira. Contudo, levando em conta que uma parente estava desempregada, convidou-a para ocupar o espaço da venda de doces de sua tenda. Assim, se concentraria somente na venda dos produtos in natura, diretos da roça. Outro exemplo foi o relato de Jo. (PA Agrovila do Funil), explicando que, enquanto teve uma baixa na produção, entregou o contato de seus clientes na venda por encomenda para Ap. Quando voltou a produzir avisou para Ap. parar de fazer as entregas para seus clientes, retomando seu nicho de mercado. 
Podemos concluir que as relações de ajuda mútua e de compartilhamento de recursos entre agricultores facilitam o acesso inicial aos mercados e contribuem para assegurar a sua continuidade, assim como o ânimo para manter a produção, além de contribuir na adaptabilidade dos produtores familiares aos obstáculos e desafios do cotidiano.

\subsection{Relações de reciprocidade entre agricultores e consumidores}

A aproximação física e pessoal inerente às estratégias de venda direta, muitas vezes, dá lugar à relações de reciprocidade entre consumidor e vendedor/agricultor. Constatamos, como descrito no capítulo anterior, a tendência da venda na rua se tornar uma comercialização de porta em porta e, posteriormente, por encomenda, segundo um processo fundado precisamente no fortalecimento progressivo destas relações de reciprocidade e a confirmação da construção e consolidação de laços afetivos pessoalizados e do sentimento de confiança.

A venda fiado é praticada para conhecidos na cidade, na comercialização de porta em porta e por encomenda ou quando o cliente declara não ter condições de pagar pelos produtos. Segundo Ap. (PA Cynthia Peter), "(...) a gente acaba vendendo fiado, né. Não tem jeito, a gente se conhece. Fiado tem que confiar, se não (eu) não vendo mais". Logo, identificamos que estas práticas contribuem na consolidação dos laços de confiança e no reconhecimento mútuo entre consumidor e produtor.

As doações e descontos na venda direta acontecem no momento do diálogo "cara a cara" como forma de agradar, retribuir algum favor ou conquistar a fidelidade e amizade do cliente. São privilegiados os clientes conhecidos com quem foi criado certo nível de amizade. A flexibilização do preço é proporcional ao nível de amizade e confiança estabelecida entre as partes. A relação de troca mercantil na venda direta permite o estabelecimento de outras relações sociais e econômicas de reciprocidade distintas daquelas baseadas somente na lógica da troca material. Existe uma coexistência 
dialética, nessas formas comerciais, entre o princípio da troca e o princípio da reciprocidade.

A consciência afetiva, como Stephane Lupasco a definiu (TEMPLE, 1998), constituída por sentimentos intersubjetivos intensificados pelas relações de reciprocidade, permite a consideração da realidade e da necessidade do outro, mesmo no processo de troca mercantil. Expande-se então a tendência à valorização das práticas cotidianas, preferências, saberes do outro, entre produtor e consumidor. Este processo permite a cumplicidade de ambos com relação à totalidade do processo consagrado no ato presente da troca . Ou seja, o ato da compra deixa de ser compreendido de forma alienada pelo consumidor, passando a considerar seu papel no processo de melhoria da produção. Igualmente, o ato da venda deixa de ser compreendido de forma alienada pelo vendedor/produtor, passando a considerar seu papel no processo de consumo, na qualidade do produto e saúde dos alimentos.

Os assentados rurais são vistos como preguiçosos e incapazes de produzir, preconceito amplamente disseminado pelos moradores da cidade de Mambaí e determinados visitantes. Contudo, a aproximação física e oral (as conversas) entre produtores e consumidores, proporcionada pela feira e outras formas de venda direta, tem ajudado a superar esta situação de preconceito. Dona Au. (PA Agrovila do Funil) comentou este fato: "O povo aqui tem muito preconceito, principalmente o pessoal de fora. Pra eles assentado é preguiçoso, não faz nada. Na feira agente mostra que o agricultor sabe produzir". Para M. (PA São José), a tendência é valorizarem cada vez mais os produtos da feira. "Agente deve manter o preço baixo, abaixo do mercado. Se não eles (as pessoas da cidade) não vem comprar. Mas com o tempo vocês vão ver".

Concluímos ainda que esta proximidade e a inerente partilha de impressões e expectativas entre consumidor e produtor, em situação "cara a cara", promove a geração de valores afetivos e éticos compartilhados, pois são co-produzidos pela relação de reciprocidade atrelada a relação de troca mercantil. Essa relação se configura também como um mecanismo de aprendizagem coletiva no sentido de Ostrom (1990, 1992). 
Jo. (PA Agrovila do Funil) vende de porta em porta e por encomenda há 20 anos. Segundo ela, "A feira foi a melhor coisa que me aconteceu". Jo. passou a vender somente na feira e comentou encontrar regularmente seus antigos clientes na mesma. Segundo Jo., sua amizade com estes antigos clientes têm ajudado bastante nas vendas na feira: “(...) são todos meus amigos, a gente se encontra agora na feira e eles continuam comprando na minha mão". As relações de confiança e amizade que Jo. estruturou ao longo do tempo permitiu que a mesma acessasse outros mercados com mais facilidade e segurança. Outros agricultores, que não tinham experiência e, principalmente, que não eram conhecidos na cidade relataram ter dificuldade na comercialização, tanto na rua, de porta em porta e na feira. Estes fatos deixam claro o papel das relações de reciprocidade, seus laços de confiança e afeto, na consolidação de formas comerciais de venda direta.

A partilha de informações sobre oferta e qualidade de produtos é também muito comum entre os consumidores. Segundo Ap., F., Va. (PA Capim de Cheiro, Agrovila do Funil e São José, respectivamente), seus maiores parceiros de venda são seus próprios clientes, pois estes divulgam seus produtos na cidade para outros potenciais compradores. Esta prática é estimulada pelos agricultores que pedem para seus clientes mais próximos avisarem as pessoas dos produtos que estão sendo oferecidos. A divulgação cruzada entre os agricultores é também realizada por todos na feira, contribuindo no fácil e rápido acesso aos produtos pelos clientes.

\subsection{O preço justo}

A percepção do agricultor e do consumidor sobre o que seria um preço justo permite entender diferentes visões do processo de construção social do preço e das relações de reciprocidade ligadas a trocas mercantis. Nos ajuda a vislumbrar o entendimento dos agricultores sobre a importância do valor de troca com relação ao valor ético a partir das individualidades constituídas nas relações de reciprocidade, levando a preocupação com 0 outro. Desenvolvemos com os entrevistados um diálogo a partir de sua percepção do que seria um "preço justo". 
Os preços dos supermercados locais, constituídos a partir de flutuações nacionais e internacionais, constitui a principal base de referência dos agricultores na construção do preço de venda de seus produtos. No entanto, em entrevista com os agricultores, identificamos que na maior parte das formas comerciais informais este preço é muitas vezes modulado ou flexibilizado de acordo com as relações pessoais de reciprocidade existentes entre produtor e cliente.

Em observação participante, testemunhei Va. (PA São José) doar e vender mais barato seus produtos para pessoas em más condições sociais e econômicas, principalmente coco e melancia, durante a feira. Ap., J. (PA Cynthia Peter) e Jo. (PA Agrovila do Funil) relataram flexibilizar o preço segundo as condições econômicas e as relações estabelecidas com o cliente. Outro exemplo foi observado na venda por encomenda: segundo Fe., Jo., Au. e outros, nesta venda, seus consumidores são selecionados, buscando aqueles de maior confiança e que valorizem o diferencial de seus produtos. Na rua e de porta em porta os valores são mais baixos, podendo ser igual ao dos supermercados, pois nestas formas os consumidores negociam muito o preço dos produtos.

Os agricultores e extrativistas participantes da feira estabeleceram, durante a primeira reunião geral de organização, que nos primeiros meses eles deveriam manter o preço abaixo do preço cobrado nos supermercados. Essa estratégia foi construída para atrair consumidores até que se consolide o hábito local de frequentar a feira e se tenha tempo de promover a valorização dos produtos locais a partir do contato com os mesmos e das relações de proximidade estabelecidas.

Fe. observou que "preço justo é quando é cobrado o quanto realmente o produto merece". Segundo a mesma, a demanda não interfere diretamente no seu preço e ela não aumentaria o preço dos seus produtos se houver muita demanda pelos mesmos. Entendemos que "preço merecido", para Fe., é aquele convencionado pelos outros vendedores da feira, que tomam como base o preço dos supermercados. Ou seja, haveria de ter um acordo coletivo sobre o preço a cobrar, sendo que ele deveria inicialmente ser mais barato que 
o preço do supermercado. Este acordo é negociado de maneira informal pela maioria e é reproduzido pelos outros vendedores. Outro exemplo aconteceu quando acompanhei Va. na feira de Posse, município vizinho de Mambaí, em novembro de 2015. Chegando a feira Va. me pediu para caminhar na feira perguntando o preço da galinha caipira para alguns feirantes e relacionasse 0 preço segundo o tamanho da galinha. Voltei e descrevi os preços segundo seus tamanhos e ele estipulou um preço para as suas galinhas.

Para Gi. (PA Paraná), produtor de melancia e mandioca que vende via intermediário e atravessador, um "preço justo é quando os dois lados saem ganhando". Gi., de forma simples e direta, expos um olhar de cumplicidade e respeito sobre o trabalho de seus consumidores diretos e indiretos: "(...) se eu cobrar mais, alguém vai sair perdendo".

Segundo Ma. (PA Capim de Cheiro), o preço justo é o valor que está no mercado: "se (eu) estiver cobrando a mais vou estar prejudicando meus clientes". Ou seja, apesar de possuir uma visão limitada sobre os múltiplos fatores que determinam os preços de produtos no mercado convencional, Ma. considera este como base de referencia para determinar seu preço. Pensa que se cobrar mais que aquele valor estará sendo injusto com seus clientes, mesmo considerando que seus produtos possam ter uma qualidade superior que os oferecidos no mercado, como bem demonstrou durante a entrevista.

Um preço justo, segundo J. (PA Cynthia Peter), “(...) é quando está satisfazendo os dois lados, sem se aproveitar. É respeitar a humanidade do povo".

Para Ap. do mesmo assentamento, "Um preço justo é um preço que seja bom para eles e para nós." Para ser justo tem que se vender o produto pelo que ele vale, para "(...) não explorar o cliente", explica Ap.. Aqui aparece claramente a preocupação não apenas social, mas econômica com a realidade das necessidades e da situação do outro, que caracteriza a lógica do princípio da reciprocidade e a sua diferença com a lógica da competição voltada ao alcance do lucro máximo individual característico do princípio da troca mercantil. O principal ensinamento dessas perguntas sobre o que é um preço justo é a confirmação da existência de regras que seguem o princípio da 
reciprocidade entre os assentados, e entre eles e os seus clientes, mesmo deslocados das suas comunidades de origem. Os agricultores, tanto por aprendizagem e educação como por necessidade, tem acumulado uma herança de valores e práticas de reciprocidade, aplicadas inclusive (já que eles não entram nessa diferenciação puramente normativa e teórica) nas suas relações de troca mercantil.

Nas entrevistas com os consumidores que frequentam a nova feira de Mambaí, em resposta a pergunta "O que é um preço justo para você?", mais de $60 \%$ reclamaram do preço dos produtos da feira. Estes demonstraram, explicita ou implicitamente, achar que o preço da feira deveria ser mais barato que o dos mercados locais. Segundo um deles: "Um preço justo é um preço barato". Segundo outro consumidor: "Um preço justo é aquele que não ultrapasse o (preço) do mercado (local)". Somente 15\% demonstraram preocupação em pagar um preço justo. Os feirantes, como descrito, demonstraram conhecimento sobre esse fato, mantendo o preço abaixo do preço dos mercados locais para garantir as vendas no começo da feira, e expressaram esperança que, com o passar do tempo e com a aproximação entre produtor e consumidor, seus produtos seriam mais valorizados.

Observamos que nenhum agricultor entrevistado declarou que determinava o preço de seus produtos segundo seus custos de produção e tempo de trabalho em horas. Ou seja, o preço dos produtos agrícolas e extrativistas dos agricultores em Mambaí é uma construção social que não depende diretamente dos custos e do tempo de trabalho para produção, transporte e venda.

Segundo essas análises, concluímos que o preço é uma construção social flexibilizada segundo as relações de reciprocidade estabelecidas entre 0 vendedor e seu consumidor. A informalidade das relações de mercado pode facilitar a construção de um preço mais justo, mas pode também dar lugar à relações de exploração entre as partes. Contudo, quanto maior a relação de proximidade, maior a importância das relações de reciprocidade em relação à lógica da troca mercantil baseada no interesse individual do lucro. As individualidades perdem espaço para uma percepção do outro e das relações 
sociais que se estabelecem, onde a reciprocidade intensifica a noção social de justiça e equidade, como vimos acontecer nas vendas por encomenda, de porta em porta e outras.

\subsection{A construção social da nova feira de Mambaí}

Os agricultores participam ativamente na construção da feira municipal da agricultura familiar. Durante anos estes atores trouxeram o tema em discussão em diversos âmbitos e pressionaram os prefeitos. A mobilização dos agricultores foi protagonizada por uma agricultora do PA Agrovila do Funil e, durante as reuniões de preparação e de articulação da feira, vários agricultores dialogaram sobre o formato e ações estratégicas ao bom funcionamento da mesma. As ações cotidianas voltadas à intensificação das relações de trocas pelo fortalecimento das práticas e relações de reciprocidades são notórias quando acompanhamos os agricultores em seu dia-a-dia.

Houve uma ação coletiva entre várias instituições (ICMBio, projetos de ONGs, Prefeitura Municipal, Emater-GO e representantes dos agricultores) para a criação e institucionalização da feira. Entre os agricultores, houve um papel histórico de promoção e legitimação da mesma (como vimos no capítulo 3), além da reprodução diária de relações socioeconômicas que permitiram seu sucesso. Contudo, em termos de ação coletiva, houve uma participação política institucional tímida por parte dos agricultores na construção da feira, que está sendo agora posta a prova, para garantir a manutenção e o crescimento da mesma.

A aprendizagem mútua, social e institucional, inerente à partilha de experiências, informações técnicas e expectativas pessoais se configura como uma relação estruturada de reciprocidade binária de tipo compartilhamento de recursos (de saberes, no caso) gerando no grupo de agricultores feirantes e de clientes fieis, sentimentos mútuos de confiança e de pertencimento. Estes sentimentos comuns produzidos por relações de compartilhamento de recursos associadas a relações de troca mercantil estão contribuindo ao reconhecimento mútuo entre produtores e entre estes e a sociedade ao seu redor. Segundo as 
entrevistas dos consumidores como dos técnicos e dos agricultores, este reconhecimento mútuo tem promovido uma re-significação da figura do agricultor familiar e do assentado rural em Mambaí e fortalecido estas categorias social e politicamente.

Apesar do papel fundamental que cada agricultor e agricultora empenhou na construção da feira, poucos vêm participando efetivamente da organização prática e logística da mesma e, assim, estão sofrendo críticas por parte das instituições envolvidas. Os técnicos relataram que a inexistência de espaços formais de deliberação, entre os agricultores e outros envolvidos, dentro da feira vem atrapalhando a articulação e sincronia entre os atores participantes.

\subsection{As relações de reciprocidade assimétricas e a exploração econômica na comercialização}

Não poderíamos deixar de abordar, tratando-se da analise de processos comerciais, a instrumentalização de relações de reciprocidade assimétricas constituintes das estratégias comerciais de agricultores familiares em Mambaí, em muitos casos usadas para assegurar práticas de exploração comercial, econômica e social.

$\mathrm{Na}$ venda para atravessadores, as relações de reciprocidade são raramente significativas. Apesar da relação de proximidade existente entre produtor e seu comprador, os produtores permanecem submetidos e imobilizados por uma relação baseada exclusivamente na lógica da troca mercantil imposta pelo atravessador por meio do interesse univalente pelo lucro individual, rompendo diálogos e negociações. O produtor permanece ignorante sobre onde, como e por quanto seu produto será vendido ao consumidor final (destino). O produtor mantém-se dependente do atravessador, que não negocia preço e não confere segurança de futuras vendas, apenas procura tirar proveito da assimetria da sua posição. Esta submissão se perpetua pela imobilidade do agricultor em alcançar novas perspectivas e pela relação de subordinação inerente as relações de reciprocidade assimétricas. 
Identificamos poucos casos em que a relação entre produtor e atravessador permeava a geração mútua de confiança e respeito pela troca de informações, pelo compartilhando de expectativas e pela confirmação de compromissos. Nestes casos, a figura histórica do atravessador passa a se descaracterizar, tornando a figura de um intermediário, alguém que estabelece uma conexão entre duas partes. Ambos passam a conhecer a origem (incluindo a forma de coleta e beneficiamento) e o destino dos produtos, permitindo o diálogo e uma construção conjunta do processo de troca, mas que permanece na maioria dos casos dominado pelo intermediário.

A venda fiado é muito usada em Mambaí. Na feira ela é usada como forma de solidariedade com as pessoas que estão sem condições de pagar no momento. Na venda por encomenda a venda fiado virou tradição, mas é entendida geralmente como uma obrigação imposta pelos consumidores, uma relação social e econômica assimétrica. Em consequência, os agricultores hoje vendem por encomenda somente para consumidores conhecidos, com quem a relação de reciprocidade tem gerado amizade ou pelo menos confiança. Com estes cliente, se estabelece geralmente uma relação cotidiana com até duas entregas por semana. As entregas são pagas somente no final do mês. Tentamos descobrir a origem deste formato de pagamento.

Observamos que, em alguns casos, essa prática é consequência de uma relação de subordinação do agricultor onde o consumidor na cidade assume um lugar de prestígio, pois este considera que comprar de um assentado rural é "uma forma de ajuda-lo", se permitindo pagar depois. Contudo, não se conseguiu caracterizar uma generalização desse ponto de vista, pois se encontrou uma diversidade de explicações não concordantes sobre o fato.

A reflexão que se confirma é que a venda fiado hoje se caracteriza como uma relação de troca desigual, associada a uma relação de reciprocidade assimétrica em que o agricultor é obrigado a receber bem mais tarde (até 30 dias ou mais) pelos produtos entregados. Apesar desta condição de risco, a venda fiado também representa um voto de confiança estratégico que garante a perpetuação de uma relação de mercado de proximidade, como detalhamos 
no tópico 3.2. Ou seja, representa um ato simbólico de confiança e compromisso entre ambas as partes, consolidando os laços sociais e as relações de troca estabelecidas, mesmo num quadro assimétrico.

Observamos a existência de expressivas relações de proximidade entre os donos de pequenos e grandes mercados na cidade, seus empregados e os agricultores fornecedores. Esta condição é consequência das relações de proximidade próprias das cidades pequenas, mesmo se a relação entre determinados indivíduos seja guiado fundamentalmente pela lógica da troca mercantil. Na venda para mercados locais como varejões, sacolões e outros pequenos comércios, identificamos que os agricultores fornecedores recebem depois das vendas dos produtos no balcão, para os clientes do estabelecimento. Ou seja, alguns dias depois da entrega se faz a contabilidade do que conseguiu ser vendido e um valor proporcional é pago ao agricultor. Se seus produtos não tiverem sido vendidos, o agricultor não recebe pela entrega. Assim, os donos dos estabelecimentos se exoneram do esforço da venda e dos riscos da volatilidade do mercado.

Os donos do supermercado disseram não poder comprar dos agricultores assentados em Mambaí, pois estes não emitem nota fiscal. Contudo, explicaram buscar alternativas ("dar um jeitinho") para ajudar os agricultores. Foi descrita uma destas alternativas: comprar os produtos sem cambio monetário, oferecendo créditos em compra no próprio supermercado no valor estipulado dos produtos. Vários supermercados da região desenvolvem essa estratégia de comprar produtos de pequenos agricultores oferecendo créditos em compras no próprio estabelecimento, sem câmbio monetário.

Esta prática foi relatada pelo prefeito e pelo técnico da EMATER como habituais. Estes atribuíram a causa desta prática à fragilidade do pequeno agricultor que fica refém das vendas nos supermercados, geralmente aqueles que não diversificam suas estratégias comerciais. Esta prática é uma forma de reciprocidade binária assimétrica na qual se reproduz uma situação de obrigação e limitação da liberdade do agricultor em que os donos dos mercados locais se colocam simbolicamente em uma posição de prestígio ao expressarem que estão fazendo um favor aos agricultores. O que observamos é que estes, por sua situação de fragilidade política e econômica, acabam se 
submetendo as exigências dos donos de mercados e supermercados locais, apesar da proximidade, entrando em relações paternalistas. Nestes casos as relações de reciprocidade são instrumentalizadas ou desviadas para facilitar a instalação e a reprodução de relações de trocas desiguais e de exploração dos produtores. 


\section{CONCLUÇÕES E RECOMENDAÇÕES}

Iniciamos a pesquisa em um cenário contraditório, onde agentes públicos, organizações e sociedade civil defendiam a inexistência de ações de comercialização e ainda mais de estratégias pensadas e voluntarias de acesso ao mercado por parte de agricultores familiares assentados em Mambaí. Apontava-se a inclusão de pequenos produtores em grandes cadeias produtivas como a única possibilidade de desenvolvimento local. A limitação deste olhar se fez clara ao confirmarmos ao longo da pesquisa o que tivemos como primeira hipótese: os agricultores de Mambaí, mesmo em condições de isolamento e sem acesso à políticas e programas do governo, reproduzem diferentes formas de comercialização construídas cotidianamente a partir de estratégias comerciais hibridamente constituídas por relações e práticas de troca mercantil associadas a relações de reciprocidade.

Adotamos a tese da importância da distinção entre o princípio da troca e da reciprocidade, de Sabourin (2012a), como método para elucidar a existência e o papel de relações e práticas econômicas movidas por outros valores para além daqueles voltados unicamente à satisfação de interesses materiais privados para acumular lucros. A caracterização destas práticas e relações de reciprocidade, ligadas ao acesso aos mercados, permite responder a nossa segunda hipótese: a existência de um papel singular destas relações de reciprocidade na constituição das estratégias de construção e sustentação dos mercados.

As entrevistas abertas e a observação participante junto aos agricultores selecionados e ao processo de construção social da feira de Mambaí foram essenciais à descrição e caracterização de diversas práticas de ajuda mútua, de trocas não monetárias, de repartição de produtos e de compartilhamento de recursos (saberes, informações, excedentes e equipamentos) estruturantes das formas de comercialização identificadas. 
As práticas de ajuda mútua e de socialização ou partilha de saberes e técnicas são determinantes para conseguir a produção do excedente e, logo, para 0 acesso aos mercados locais e regionais (carona solidaria, venda na meia). Além de intensificarem processos de aprendizagem coletiva ao longo da atividade comercial.

Todas as formas de comercialização identificadas e caracterizadas em Mambaí são desenvolvidas na informalidade. Sem contratos formais, essas formas comerciais são articuladas a partir de laços sociais de proximidade onde as relações de reciprocidade (ajuda mútua, solidariedade, compartilhamento de recursos) cumprem papel fundamental em sua construção. Na ausência de uma organização maior dos agricultores e de uma regulação pública das práticas comerciais, a informalidade deixa esses produtores em uma posição vulnerável perante os comerciantes, principalmente nos casos da venda indireta. Nestes casos, a informalidade facilita a permanência e a reprodução de relações de reciprocidade assimétricas, podendo levar à submissão, obrigação e exploração do produtor pelo comerciante (atravessador ou donos de pequenos e grandes mercados locais). Alguns fatores explicam a manutenção desta informalidade: a inadequação dos produtos à regulação sanitária, a dificuldade na obtenção do DAP para emissão de nota fiscal, a maior flexibilidade e facilidade em promover mercados informais, a falta de organização local e regional dos agricultores, assim como a falta de políticas apropriadas para a regulação das formas comerciais próprias da agricultura familiar.

As relações de reciprocidade cumprem diferentes papéis, em particular nas diversas formas de venda direta. As falas dos agricultores indicam como 0 contato direto com o consumidor permite o dialogo e a partilha de informações e expectativas, podendo gerar interconhecimento, respeito mútuo, simpatia, amizade e confiança. As palavras dos agricultores mostram que tomar conhecimento da realidade do outro é o primeiro passo para entender e se preocupar com as suas necessidades básicas. Essa empatia mútua leva a produção de valores afetivos e éticos entre produtor e cliente e, progressivamente, a fidelização da relação de troca mercantil e a reprodução 
cíclica das próprias relações e práticas de solidariedade, tendendo a um equilíbrio nas relações de troca.

Esta sobreposição da relação de troca mercantil com relações de reciprocidade conduz à criação de códigos de ética e valores morais compartilhados. Concluímos que essas relações, práticas e valores contribuem de forma incisiva na construção e reprodução social de mercados mais justos, conferindo resiliência às estratégias de comercialização dos agricultores familiares assentados em Mambaí, independente da presença pública e de leis regulatórias. Além disso, a manutenção dos laços sociais de reciprocidade facilitam o desenvolvimento produtivo e o acesso aos mercados, contribuindo na permanência das famílias nos assentamentos, independente da falta de acesso à créditos rurais e à uma assistência técnica adequada.

$\mathrm{Na}$ venda indireta, as relações de proximidade entre agricultor e intermediário ou estabelecimentos comerciais favorecem o diálogo e a construção de estratégias comerciais mais flexíveis. Por outro lado, a figura histórica do atravessador, calcada no distanciamento pessoal, contribui à reprodução de relações de subordinação e obrigação do agricultor. Esta forma de venda vem se reproduzindo durante muitos anos em Mambaí com relação ao pequi, especificamente. Os agricultores fizeram muitos cursos e sabem agregar valor aos produtos, como vimos na contextualização, mas não o fazem por falta de alternativas comerciais para este tipo de produto.

A análise dos nossos resultados mostra claramente uma evolução na trajetória de comercialização dos agricultores. Existe uma complexificação da associação entre modalidades de venda direta e indireta e o papel específico das relações de reciprocidade entre produtor e consumidores para cada etapa dessa trajetória. Essa trajetória inicia com a venda em um ponto fixo na rua, passa para a venda de porta em porta, a venda por encomendas e, finalmente, a venda na feira.

Essa passagem de uma modalidade a outra exige um esforço, um cuidado e um grau de intensificação não apenas da quantidade e da qualidade dos produtos, mas do domínio das práticas e regras da reciprocidade humana. 
Não se trata apenas de civilidade, de cuidados com as pessoas ou de generosidade, se trata da intensidade da mobilização de recursos da reciprocidade: a frequência da interação social, a força do vinculo pessoal produtor/cliente e ainda do uso da palavra, tanto instrumental como simbólica, no processo de comercialização.

Se a venda na feira do produtor depende também de um processo de especialização ou de uma ação coletiva quando tem que ser criada, como em Mambaí, a manutenção dessas modalidades e a fidelização da clientela dependem também das relações de reciprocidade com os consumidores e entre os produtores feirantes. Observamos ainda que a ação pública de institucionalização de mercados de venda direta, como a feira de Mambaí, depende da participação dos agricultores familiares e de suas organizações voltadas a um processo institucional de ação coletiva.

A maior parte das políticas públicas, dos projetos de desenvolvimento rural e das pesquisas científicas não levam em consideração as particularidades da agricultura familiar $e$ as diferentes racionalidades intrínsecas às suas práticas cotidianas. Dessa forma, faz-se necessário aprimorar métodos e ferramentas adequados para conhecer, compreender e apoiar as diferentes racionalidades sociais e econômicas das relações humanas, suas formas e estruturas e, assim, entender a complexidade da interação entre a dimensão material e instrumental da economia analisada do ponto de vista exclusivo da lógica da troca mercantil e a dimensão social e humana das regras, normas, valores e códigos sociais que orientam, possibilitam e sustentam as transações econômicas.

A assistência técnica e a extensão rural devem buscar compreender a multiplicidade do rural brasileira e desenvolver mecanismos de fortalecimento de suas práticas construídas no cotidiano a partir de identidades, recursos e relações a cada território. Nos assentamentos rurais de Mambaí, no nordeste do Goiás, as estratégias comerciais desenvolvidas por agricultores se demonstraram estáveis e perenes quando estruturadas por relações de reciprocidade e pelos inerentes laços afetivos e valores éticos de confiança e justiça gerados por estas relações. 
Os agricultores sentem confiança em produzir se possuem segurança em vender. O início da feira e a promessa do transporte gratuito pela prefeitura mobilizaram diversas famílias a começarem a produzir, principalmente aquelas que já comercializavam mediante outras modalidades.

Diante deste panorama, nos restaria aprofundar a questão de como formalizar as estratégias comerciais próprias da agricultora familiar, buscando organização profissional, apoio público e garantia de direitos, sem esquecer ou suprimir as relações e práticas de reciprocidade que as estruturam. No entanto a organização coletiva dos agricultores continua essencial para evitar a dependência de relações assimétricas levando a exploração do produtor, e para negociar apoio e regulação pública.

As relações de reciprocidade podem também ser entendidas de forma utilitarista, como sendo mobilizadas para favorecer a eficácia das trocas mercantis, em particular no que diz respeito à cooperação e coordenação para facilitar ou estabilizar as transações econômicas. Porém, não se tratou aqui de caracterizar o papel da reciprocidade visando favorecer o desenvolvimento da economia da troca mercantil, mas de valorizar um envolvimento humano que respeite as diferentes formas comerciais protagonizadas por atores locais, dando visibilidade às relações humanas que permitam a construção de uma sociedade mais equânime fundada em valores éticos $e$ afetivos compartilhados. 


\section{REFERÊNCIAS BIBLIOGRÁFICAS}

ABRAMOVAY, Ricardo. Anticapitalismo e Inserção Social dos Mercados. Revista de Sociologia da USP, São Paulo, v. 21, n. 1. 2009.

AZEVEDO, P. et FAULIN, E. Comercialização na agricultura familiar. In: SOUZA FILHO, H.M.; BATALHA, M. O. (Orgs.). Gestão integrada da agricultura familiar. São Carlos: Edufscar, 2005.

BAUSGIRAUD, M. Normas ambientais e transformações das práticas de gestão dos recursos naturais: o exemplo da APA Nascentes do Rio Vermelho. Dissertação (Mestrado em Engenharia Agrícola e Desenvolvimento) - Escola Internacional de Engenharia de Agro Desenvolvimento, França, 2013.

BERTRAN, P. Cerratenses. Brasília: Verano, 1998.

Brasil. Lei n. 11.326 de 24 de julho de 2006. Estabelece as diretrizes para a formulação da Política Nacional da Agricultura Familiar e Empreendimentos Familiares Rurais. Diário Oficial da União, Brasília, p.1, 25 jul. 2006.

Brasil. Ministério da Fazenda. Coordenação de administração e logística. Diário Oficial da União, Brasília, 28 de ago. 2015, p. 33.

BONNAL, Philippe. et MALUF, Renato S. Políticas de desenvolvimento territorial e multifuncionalidade da agricultura familiar no Brasil. In: CAZELLA, A., BONNAL, P., MALUF, R. (Orgs.). Agricultura Familiar: multiplicidade e desenvolvimento territorial no Brasil. Rio de Janeiro: Mauad X, 2009.

CARVALHO, I. S. H. de. Potenciais e Limitações do Uso Sustentável da Biodiversidade do Cerrado: um estudo de caso da Cooperativa Grande Sertão no Norte de Minas. Dissertação (Mestrado em Engenharia Florestal) Universidade de Brasília, Brasília, 2007.

CHABAL, M., Les Structures Élémentaires de Réciprocité. Cauris, 2005. Disponível em: <http://afrique.cauris.free.fr/mireille.html> Acesso em: 03 ago. 2015. 
Congresso da Sociedade Brasileira de Economia, Administração e Sociologia Rural, 48ㅜㅗ 2010, Campo Grande. GAZOLLA, Marcio. et PELEGRINI, Gelson. A Construção Social de Mercados pelos Agricultores: o caso das agroindústrias familiares. Campo Grande: UFMS, 2010.

DUARTE, Laura Maria Goular. Agricultura Familiar: mas a final, do que estamos falando? Palestra. 18 Café Científico. Brasília, 2014.

ELLIS, Frank. Rural livelihoods and diversity in developing countries. Oxford: Oxford University Press, 2000.

ELOY, L.; LUDEWIGS, T. Relatório de trabalho de campo na APA Nascentes do Rio Vermelho. Universidade de Brasília. Centro de Desenvolvimento Sustentável, 2013. Dados não publicados.

Encontro Nacional de Pós-Graduação em Meio Ambiente e Sociedade, XII, 2015, Brasília. AVELINE, Igor; PENEIREIRO, Fabiana; BARROSO, Eduardo; MAMEDE, Guilherme; LUDEWIGS, Thomas. A Extensão Universitária na construção coletiva da sustentabilidade em assentamentos rurais: o caso do Projeto de Extensão "Promovendo o Uso do Cerrado em Pé". Brasília: UnB, 2015.

Encontro Nacional de Geografia Agrária, XIX, 2009, São Paulo. CANDIOTTO, Luciano Pessoa. Aspectos Históricos e Conceituais da Multifuncionalidade da Agricultura, São Paulo: USP, 2009.

GEHLEN, Ivaldo. Políticas Públicas e Desenvolvimento Social Rural. São Paulo Perspectivas. São Paulo, v. 18. n. 2, 2004.

IBGE. Censo agropecuário 2006: agricultura familiar: primeiros resultados. Rio de Janeiro, 2009.

INSTITUTO NACIONAL DE COLONIZAÇÃO E REFORMA AGRÁRIA - INCRA. Pesquisa confirma que reforma agrária é um instrumento de combate à pobreza. Jornal. Publicação Especial do INCRA, ano 1, n. 2. Dezembro, 2010.

MAUSS, Marcel. Sociologia e Antropologia. Trad. Paulo Neves. São Paulo, Cosac Naify, 2013. 
MAZZETO SILVA, Carlos Eduardo. Ordenamento Territorial no Cerrado brasileiro: da fronteira monocultora à modelos baseados na sociobiodiversidade. Desenvolvimento e Meio Ambiente, Paraná, n. 19, Editora UFPR, 2009.

MENDRAS, H. Les sociétés paysannes. Eléments pour une théorie de la paysannerie. Paris, Armand Colin, 1976.

NIEDERLE, Paulo André. Mercantilização, Estilos de Agricultura e Estratégias Reprodutivas dos Agricultores Familiares de Salvador das Missões, RS. 2007. 219 f. Dissertação (Mestrado em Desenvolvimento Rural) - Faculdade de Ciências Econômicas, UFRGS, Porto Alegre, 2007.

NIEDERLE, Paulo André. Afinal, que Inclusão Produtiva? A contribuição dos novos mercados alimentares. Oficina "Agricultura familiar: perspectivas atuais e futuro". Brasília, 2014.

OLIVEIRA, Roberto Cardoso de. Ensaios Antropológicos Sobre Moral e Ética. Rio de Janeiro: Tempo Brasileiro,1996.

OLIVEIRA, Maria do Socorro L.; DUQUE, Ghilaine. Reciprocidade e sociabilidade no Cariri Paraibano. In: REUNIÃO BRASILEIRA DE ANTROPOLOGIA, 24a , 2004, Olinda. Anais eletrônicos. Olinda: ABA, 2004.

OSTROM, E. Governing the Commons; the evolution of institutions for collective action. New York: Cambridge University Press, 1990.

OSTROM, E. Crafting Institution of Self-Governing Irrigation Sistem. San Francisco: ICS, Institute for Contemporary Studies, 1992.

OSTROM, E. A Behavioral Approach to the Rational-Choise Theory of Collective Action. American Political Science Review, n. 92, 1998.

POLANYI, Karl. A Grande Transformação: as origens da nossa época. Trad. Fanny Wrabel. 2. Ed. Rio de Janeiro: Compus, 2000. 
PLOEG, Jan Douwe van der. Camponeses e impérios alimentares: lutas por autonomia e sustentabilidade na era da globalização. Trad. Rita Pereira. Porto Alegre: UFRGS, 2008.

REIS, Victória Alves. Avaliação da Implantação de Sistemas Agroflorestais como Alternativa à Agricultura de Derruba e Queima: estudo de caso em Mambaí, Goiás. 20014. Monografia (Bacharel em Engenharia Ambiental) Faculdade de Tecnologia, UnB, Brasília, 2014.

SABOURIN, Eric. Marcel Mauss: da dádiva à questão da reciprocidade. Revista Brasileira de Ciências Sociais, vol. 23. n. 66. 2008.

SABOURIN, Eric. Camponeses do Brasil: entre a troca mercantil e a reciprocidade. Rio de Janeiro: Garamond, 2009.

SABOURIN, Eric. Sociedades e Organizações Camponesas: uma leitura através da reciprocidade. Porto Alegre: Editora da UFRGS, 2011.

SABOURIN, Eric. Reciprocidade e Análise de Política Pública no Brasil. Ruris. V. 6, n. 2, 2012a.

SABOURIN, Eric. A Construção Social dos Mecanismos de Qualificação e Certificação. REDD - Revista Espaço de Diálogo e Desconexão, Araraquara, v. 4, n. 2, $2012 b$.

SABOURIN, Eric. Acesso aos Mercados para a Agricultura Familiar: uma leitura pela reciprocidade e a economia solidária. Revista Economia do Nordeste, Fortaleza, Fortaleza, v. 45, 2014.

SACHS, Ignacy. Caminhos para o desenvolvimento sustentável. Coleção Idéias Sustentáveis. Rio de Janeiro: Ed. Garamond, 2006.

SPAROVEK, Gerd. A qualidade dos assentamentos da reforma agrária brasileira. São Paulo: Páginas \& Letras Editora \& Gráfica, 2003.

TEMPLE, Dominique . L'économie humaine. In: La revue du MAUSS. v. 1, n. 10, 1997. 
TEMPLE, Dominique. Le Principe d'Antagonisme de Stéfane Lupasco. 1998. Bulletin Interactif Du Centre International de Recherches et Études Transdisciplinaires, CIRET, n. 13, 1998. Disponível em: <http://cirettransdisciplinarity.org/bulletin/b13c13.php> Acessado em: 22 de julho de 2015.

TEMPLE, Dominique. Projections Post-Capitalistes: pourquoi avons-nous besoin d'une autre logique. In: Porque Precisamos de Outra Lógica? Tradução de Éric Sabourin, 2011. Disponível em < http://dominique.temple.free.fr/reciprocite.php?page=reciprocidad 2\&id article= $\underline{290}>$ Acesso em: 10 de julho de 2015.

TEMPLE, Dominique. Teoría de la Reciprocidad. La Paz, Bolívia: PADEP/GTZ, 2003.

TEMPLE, Dominique. Le Carre Magique de la Réciprocité. Cauris, 2005. Disponível em < http://afrique.cauris.free.fr/magic.html > Acesso em: 17 de julho de 2015.

TEMPLE, Dominique. L'entreprise de Reciprocité II: l'entreprise individuelle responsable et l'entreprise communautaire. Cauris, 2005. Disponível em < http://afrique.cauris.free.fr/recientr.html > Acesso em: 27 de junho de 2015.

VIEIRA, Débora de Faria Albernaz. Influência do Programa de Aquisição de Alimentos na Comercialização dos Produtos da Agricultura Familiar: 0 caso do município de Paracatu em Minas Gerais. Brasília, 2008. 162 f. Dissertação (Mestrado em Agronegócios) - Faculdade de Agronomia e Medicina Veterinária, UnB, Brasília, 2008.

WILKINSON, John. Sociologia econômica, a teoria das convenções e o funcionamento dos mercados: inputs para analisar os micro e pequenos empreendimentos agroindustriais no Brasil. Ensaios FEE, Porto Alegre, v. 23, n. 2. 2002. 


\section{ANEXO 1}

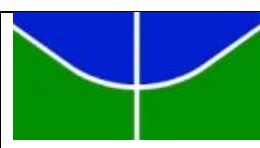

Brasília
Universidade de
Data da aplicação:

Duração:

Assentamento:

Lote:
Horário início da entrevista:

Horário Término da entrevista:

Entrevistador:

Entrevistado:

1a ETAPA TIPOLOGIA DAS FORMAS COMERCIAIS - Mambaí/GO

Número da entrevista:

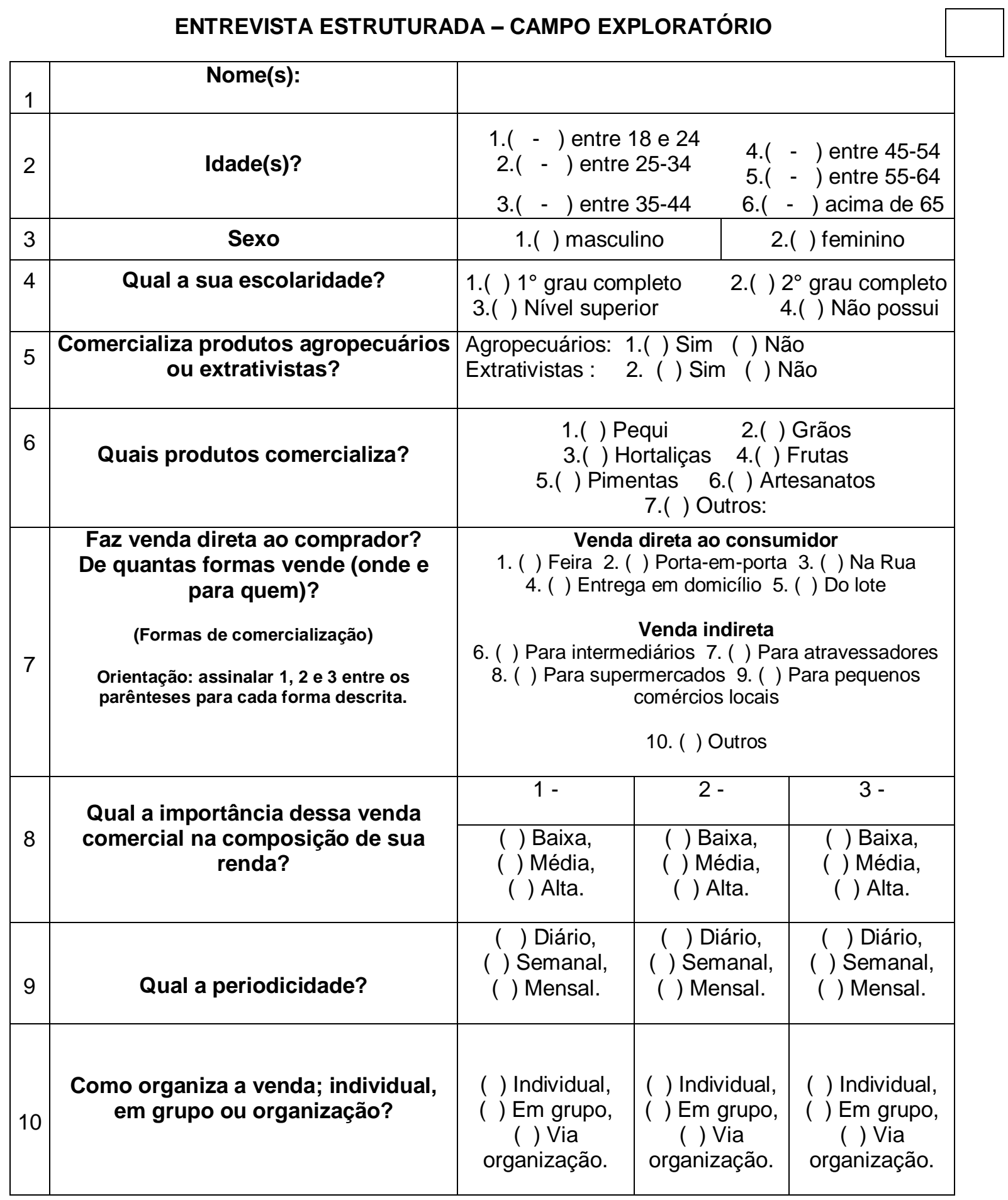




\begin{tabular}{|c|c|c|c|c|}
\hline $\begin{array}{c}\text { Faz algum tipo de contrato formal? } \\
\text { (Qual a estratégia de comercialização?) }\end{array}$ & $\begin{array}{c}\text { ( ) Informal, } \\
\text { ( ) Formal. }\end{array}$ & $\begin{array}{c}\text { ( ) Informal, } \\
\text { ( ) Formal. }\end{array}$ & $\begin{array}{c}\text { ( ) Informal, } \\
\text { ( ) Formal. }\end{array}$ \\
\hline 11 & $\begin{array}{c}\text { Como são comercializados seus } \\
\text { produtos? }\end{array}$ & $\begin{array}{c}\text { ( ) Frescos, } \\
\text { ( ) Beneficiados }\end{array}$ & $\begin{array}{c}\text { ( ) Frescos, } \\
\text { ( ) Benefic. }\end{array}$ & $\begin{array}{c}\text { ( ) Frescos, } \\
\text { ( ) Benefic. }\end{array}$ \\
\hline
\end{tabular}

Conhece outros agricultores que comercializam no assentamento? Quais?

\section{Comentários:}




\section{ANEXO 2}

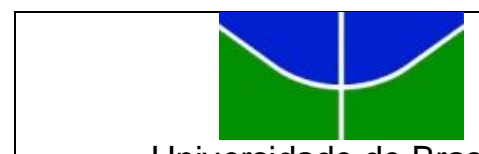

Universidade de Brasília
Data da aplicação:

Duração:

Assentamento:

Lote:
Horário início da entrevista:

Horário término da entrevista:

Entrevistador:

Entrevistado:

2ㄹ ETAPA

Número da entrevista:

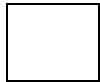

ROTEIRO - ENTREVISTA ABERTA

Estratégia de mercado

Forma de comercialização

PERGUNTAS NORTEADORAS

INFORMAÇÕES A SEREM COLETADAS

ORIGEM E TRAJETÓRIA

\begin{tabular}{|c|c|c|}
\hline 1 & Como surgiu essa forma de venda? & Origem dessa forma de comercialização \\
\hline 2 & $\begin{array}{c}\text { Você comercializa sozinho ou com } \\
\text { outros agricultores? } \\
\text { ou } \\
\text { Faz alguma forma de ajuda (mútua) } \\
\text { para comercializar? }\end{array}$ & \\
\hline 3 & $\begin{array}{l}\text { É um grupo informal ou uma } \\
\text { organização formalizada } \\
\text { (associação, cooperativa, etc) }\end{array}$ & \\
\hline 4 & $\begin{array}{l}\text { Como funciona o grupo ou forma de } \\
\text { ajuda mútua? }\end{array}$ & \\
\hline 5 & $\begin{array}{c}\text { Existiu a participação ou apoio de } \\
\text { alguma instituição ou organização } \\
\text { (pública, não-governamental ou } \\
\text { privada) e/ou projeto? }\end{array}$ & \\
\hline 6 & $\begin{array}{l}\text { Existe algum tipo de contrato ou } \\
\text { acordo firmado com seus }\end{array}$ & $\begin{array}{l}\text { ( ) Mercado spot - sem acordos/contratos } \\
\text { ( ) Contratos informais / tipo de negociação }\end{array}$ \\
\hline
\end{tabular}




\begin{tabular}{|c|c|c|}
\hline & compradores? Qual? & ( ) Contratos formai \\
\hline 6.1 & $\begin{array}{l}\text { Grupo informal: } \\
\text { Detalhar as práticas de ajuda mútua }\end{array}$ & $\begin{array}{l}\text { a) Cara a Cara / binária: } \\
\text { Carona solidária ou ajuda entre dois vizinhos na comercialização, } \\
\text { "contrato falado", } \\
\text { b) Compartilhar recursos: } \\
\begin{array}{c}\text { Compartilhar ponto de venda, nichos de mercado, produtos (repartir), } \\
\text { informações sobre preço/técnicas/processamento }\end{array}\end{array}$ \\
\hline 6.2 & $\begin{array}{l}\text { Grupo formal: associação ou } \\
\text { cooperativa }\end{array}$ & $\begin{array}{l}\text { Quais as regras de cooperação, colaboração, manutenção } \\
\text { do patrimônio, etc, }\end{array}$ \\
\hline 7 & $\begin{array}{l}\text { Como se dá a consolidação? } \\
\text { Quais as relações sociais com os } \\
\text { compradores? }\end{array}$ & $\begin{array}{l}\text { Venda para intermediários: } \\
\begin{array}{l}\text { a) Reciprocidade assimétrica } \\
\text { b) Reciprocidade simétrica } \\
\text { Venda direta: } \\
\text { a) Qualidade/quantidade especial; } \\
\text { b) Identifica clientes privilegiados, cuida deles; } \\
\text { c) Preço especial; } \\
\text { d) Há uma fidelização dos clientes; } \\
\text { e) Faz conversas; } \\
\text { f) Relação pessoal, interessada. }\end{array}\end{array}$ \\
\hline 8 & $\begin{array}{c}\text { O que essas alianças e } \\
\text { cooperações (dispositivos } \\
\text { sociais) permitiram alcançar? } \\
\text { E nos dias de hoje? }\end{array}$ & Destacar conquistas e capacidades alcançadas. \\
\hline
\end{tabular}

\section{ESTRATÉGIA DE VENDA}

\begin{tabular}{|l|c|c|}
\hline & $\begin{array}{c}\text { Qual a importância dessa venda } \\
\text { para a renda familiar (quantos \% } \\
\text { representa)? }\end{array}$ & \\
\hline 9 & $\begin{array}{c}\text { Qual a quantidade de produtos } \\
\text { vendidos nessa forma de } \\
\text { comercialização? }\end{array}$ & \\
\hline 10 & O que é, para você, um preço justo? & \\
\hline
\end{tabular}




\begin{tabular}{|l|c|c|c|}
\hline 11 & $\begin{array}{c}\text { Como é o processo de negociação } \\
\text { da venda na comercialização? }\end{array}$ & $\begin{array}{c}\text { Calculo fundamentalmente interessado e/ou monetário? } \\
\text { Existem outras formas de negociação e partilha? } \\
\text { Qual a forma de negociação de preço: } \\
\text { unilateral, negociado fixo ou negociado flexivel. }\end{array}$ \\
\hline \multicolumn{2}{|c|}{ Caracterizar relações de troca: } \\
$\begin{array}{l}\text { a) } \\
\text { a) }\end{array}$ & $\begin{array}{c}\text { Relações } \\
\text { b) relações de reciprocidade dominadas pela lógica de troca material ou monetária. (Ex. na venda } \\
\text { para supermercados, onde não há o diálogo e negociação de preços). }\end{array}$ \\
\hline
\end{tabular}

Quais relações de solidariedade, ajuda mútua e outros existem hoje no processo de comercialização?

( ) solidariedade, ( ) ajuda mútua, ( ) partilha, ( ) competição,

Se configuram enquanto dispositivos sociais? Quais?

Qual o papel das mesmas no funcionamento dessa estratégia?

Ex.: fortalecer laços sociais, promover determinadas ações, ajudar a sustentar essa forma comercial, etc. 


\section{Anexo 3}

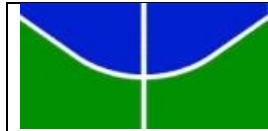

Universidade de Brasília

Data da aplicação:

Dia da semana:

Duração:
Horário início da entrevista:

Horário Término da entrevista:

Entrevistador:

Entrevistado:

3 ETAPA

REALIZADA NA CIDADE DE MAMBAÍ/GO

Perguntas orientadoras da pesquisa aberta aos consumidores diretos:

\section{PESQUISA}

Número da entrevista:
Estratégia de mercado

\section{Forma de consumo}

Por que opta por essa forma de consumo (de mercado)?

Quais práticas e relações contribuem para sua fidelidade e procura por esse mercado?

\begin{tabular}{|c|c|c|}
\hline 1 & Qual a sua relação com o produtor / vendedor? & $\begin{array}{l}\text { Credibilidade (reputação), confiança, } \\
\text { proximidade, amizade } \\
\text { Dispositivos possíveis: compra fiado, pagamento } \\
\text { antecipado, ganha produtos extras, pede produtos, } \\
\text { visita produção, troca sementes/conhecimentos. }\end{array}$ \\
\hline 2 & Qualidade dos produtos & $\begin{array}{l}\text { ( ) sanitária, ( ) visual, } \\
\text { ( ) qualidade organolépticas, } \\
\text { ( ) produção orgânica, } \\
\text { ( ) qualidade de procedência, } \\
\text { ( ) outros: }\end{array}$ \\
\hline 3 & Regularidade & $\begin{array}{l}\text { Semanalmente, quinzenalmente, } \\
\text { mensalmente, etc. }\end{array}$ \\
\hline 4 & Diversificação dos produtos & \\
\hline 5 & Preço & Boa relação custo/benefício \\
\hline 6 & Acessibilidade ou praticidade & \\
\hline
\end{tabular}




\begin{tabular}{|l|c|c|}
\hline 8 & $\begin{array}{c}\text { Quantidade de produção } \\
\text { (com relação as suas necessidades) }\end{array}$ & "Escala de produção" \\
& & \\
\hline
\end{tabular}

Comentários: 